
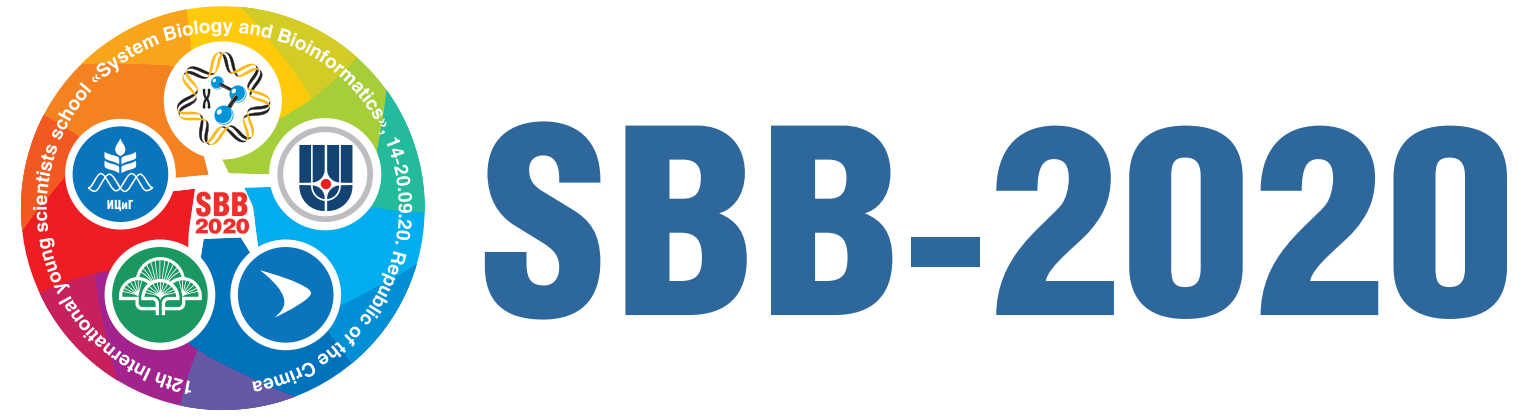

\title{
Systems Biology and Bioinformatics
}

The 12th International Young Scientists School

14-20 September 2020, Republic of the Crimea, Russia https://conf.icgbio.ru/sbb2020/ 
12-я Международная школа молодых ученых

"Системная Биология и Биоинформатика»

12th International young scientists school

"System Biology and Bioinformatics", SBB-2020

14-20 сентября 2020 года, в городах Ялта и Севастополь, Республика Крым, Россия

Школа поддержана Курчатовским геномным центром Института цитологии и генетики Сибирского отделения Российской академии наук, проект № 075-15-2019-1662

Школа поддержана Российским фондом фундаментальных исследований (РФФИ), проект № 20-04-22021

\section{Организаторы}

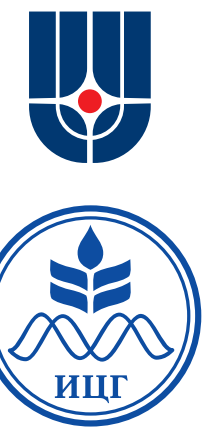

Федеральное государственное бюджетное учреждение «Национальный исследовательский центр «Курчатовский институт», НИЦ КИ, Москва, Россия

Федеральное государственное бюджетное научное учреждение «Федеральный исследовательский центр Институт цитологии и генетики Сибирского отделения Российской академии наук», ИЦиГ СО РАН, Новосибирск, Россия

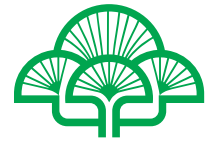

Федеральное государственное бюджетное учреждение науки «Ордена Трудового Красного Знамени Никитский ботанический сад Национальный научный центр РАН», ФГБУН «НБС-ННЦ», пгт Никита, Ялта, Республика Крым, Россия

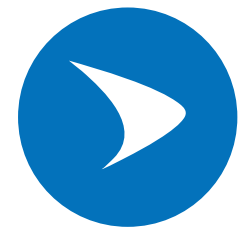

ФГАОУ ВО «Севастопольский государственный университет», СевГУ, Севастополь, Республика Крым, Россия

\section{Спонсоры}

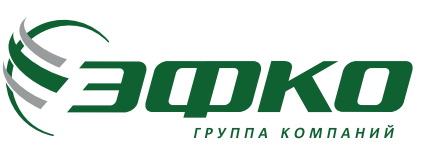

БСИНТО^

научно-производственная компания
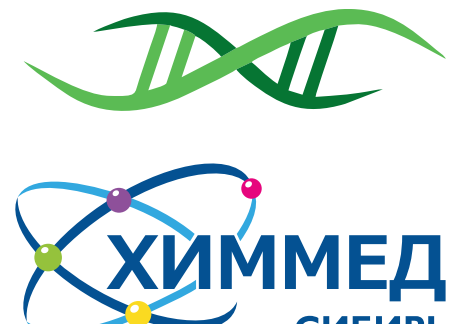

СИБИРЬ
$\mathrm{AO}$ «Управляющая компания «ЭФКО»»

ООО «Синтол»

ООО «Биолабмикс»

ООО «Химмед Сибирь»

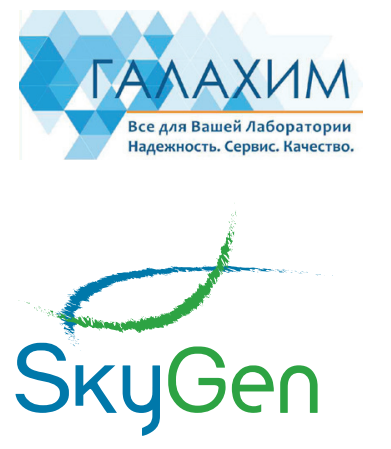

ООО «ГАЛАХИМ»

$\mathrm{OOO} \mathrm{«СкайДжин»}$

ЕвpDreH 3АО «Евроген» 
Institute of Cytology and Genetics, Siberian Branch

of the Russian Academy of Sciences

\section{SYSTEMS BIOLOGY AND BIOINFORMATICS (SBB-2020)}

The Twelfth International Young Scientists School

Abstracts

September 14-20, 2020

Republic of the Crimea, Russia 
УДК 575

S98

Systems Biology and Bioinformatics (SBB-2020) : The Twelfth International Young Scientists School (September 14-20, 2020, Novosibirsk, Russia); Abstracts / Institute of Cytology and Genetics, Siberian Branch of the Russian Academy of Sciences. - Novosibirsk : ICG SB RAS, 2020. - 113 pp. ISBN 978-5-91291-053-1. - DOI 10.18699/SBB-2020-00.

\section{Контактная информация}

Оргкомитет Школы SBВ-2020, ИЦиГ СО РАН:

е-мейл: sbb2020@bionet.nsc.ru

сайт: https://conf.icgbio.ru/sbb2020/

630090, Россия, Новосибирск, проспект Академика Лаврентьева, 10

тел.: +7(383) 363-49-77, факс: +7(383) 333-12-78

сайт ИЦиГ СО РАН: www.bionet.nsc.ru 


\section{Программный комитет}

\section{Сопредседатели}

Президент НИЦ «Курчатовский институт» (Москва, РФ), чл.-кор. РАН Ковальчук Михаил Валентинович; Научный руководитель ИЦиГ СО РАН (Новосибирск, РФ), академик РАН Колчанов Николай Александрович

Члены Программного комитета

Плугатарь Юрий Владимирович, чл.-кор. РАН, ФГБУН «НБС-ННЦ», Ялта, Республика Крым, РФ — заместитель председателя;

Евстигнеев Максим Павлович, д.ф.-М.Н., профессор, СевГУ, Севастополь, Республика Крым, РФ — заместитель председателя;

Кочетов Алексей Владимирович, д.б.н., чл.-кор. РАН, директор ИЦиГ СО РАН, Новосибирск, РФ; Афонников Дмитрий Аркадьевич, д.б.н., в.н.с., ИЦиГ СО РАН, Новосибирск, РФ;

Благов Александр Евгеньевич, д.ф.-м.Н., НИЦ «Курчатовский институт», Москва, РФ; Дебабов Владимир Георгиевич, д.б.н., академик РАН, НИЦ «Курчатовский институт», Москва, РФ; Дьякова Юлия Алексеевна, к.ф.-м.н., НИЦ «Курчатовский институт», Москва, РФ; Иванисенко Владимир Александрович, к.б.н., ИЦиГ СО РАН, Новосибирск, РФ; Коневега Андрей Леонидович, к.ф.-М.Н., НИЦ «Курчатовский институт», Москва, РФ; Костров Сергей Викторович, чл.-кор. РАН, НИЦ «Курчатовский институт», Москва, РФ; Лашин Сергей Александрович, к.б.н., в.Н.С., ИЦиГ СО РАН, Новосибирск, РФ; Лиховской Владимир Владимирович, д.С-х.Н., врио директора ФГБУН «ВННИИВиВ «Магарач» РАН»; Митрофанова Ирина Вячеславовна, д.б.н., чл.-Кор. РАН, ФГБУН «НБС-ННЦ», Ялта, Республика Крым, РФ; Патрушев Максим Владимирович, к.б.н., НИЦ «Курчатовский институт», Москва, РФ;

Салина Елена Артемовна, д.б.н., г.н.с., заслуженный деятель науки, ИЦиГ СО РАН, Новосибирск, РФ; Санду Роман Александрович, д.т.н., НИЦ «Курчатовский институт», Москва, РФ;

Свердлов Евгений Давидович, д.Х.Н., профессор, академик РАН, Центр геномных исследований мирового уровня Научно-исследовательский центр «Курчатовский институт», Москва, РФ; Федосов Дмитрий Юрьевич, к.ф.н., НИЦ «Курчатовский институт», Москва, РФ; Чуклин Алексей Александрович, Директор Дирекции научной и инновационной деятельности, СевГУ, Севастополь, Республика Крым, РФ;

Шевчук Оксана Михайловна, д.б.н., зам. директора ФГБУН «НБС-ННЦ», Ялта, Республика Крым, РФ; Яненко Александр Степанович д.б.н., НИЦ «Курчатовский институт», Москва, РФ

\section{Организационный комитет}

Зубова Светлана Васильевна, рук. сектора, ИЦиГ СО РАН, Новосибирск, РФ председатель Организационного комитета;

Петровская Ольга Васильевна, заведующая аспирантурой, ИЦиГ СО РАН, Новосибирск, РФ ученый секретарь Школы;

Бакова Надежда Николаевна, к.с.-Х.н., ФГБУН «НБС-ННЦ», Ялта, Республика Крым, РФ;

Водясова Екатерина Александровна, ФИЦ ИнБЮМ, СевГУ, Севастополь, Республика Крым, РФ;

Дегтяр Ирина Викторовна, м.н.С., НИЛ «Молекулярная и клеточная биология», СевГУ, Севастополь, Республика Крым, РФ;

Завьялова Оксана Стефавовна, к.ф.-м.Н., зав. кафедрой «Физика», СевГУ, Севастополь, Республика Крым, РФ; Замятин Владимир, ст. лаб., ИЦиГ СО РАН, Новосибирск, РФ;

Лантушенко Анастасия Олеговна, к.ф.-м.н., В.н.с. НИЛ «Молекулярная и клеточная биология», СевГУ, Севастополь, Республика Крым, РФ;

Линкевич Павел Евгеньевич, вед. инженер-программист, ИЦиГ СО РАН, Новосибирск, РФ; Мегер Яков Васильевич, студент кафедры «Физика», СевГУ, Севастополь, Республика Крым, РФ; Паштецкий Андрей Владимирович, заместитель директора по научно-организационной деятельности, ФГБУН «НБС-ННЦ», Ялта, Республика Крым, РФ; Рассказов Дмитрий Александрович, начальник центра, ИЦиГ СО РАН, Новосибирск, РФ; Смирнова Анна Александровна, инженер, ИЦиГ СО РАН, Новосибирск, РФ; Токпанов Ерлан Аскарович, начальник отдела, ИЦиГ СО РАН, Новосибирск, РФ; Харкевич Андрей Владимирович, ведущий специалист, ИЦиГ СО РАН, Новосибирск, РФ; Чалкова Татьяна Федоровна, начальник отдела, ИЦиГ СО РАН, Новосибирск, РФ 


\section{НИЦ «Курчатовский институт», Москва}

Президент НИЦ «Курчатовский институт» - член-корреспондент РАН, профессор, д. ф.-м. наук Михаил Валентинович Ковальчук Директор НИЦ «Курчатовский институт» - д. ф.-м. наук Александр Евгеньевич Благов

Национальный исследовательский центр «Курчатовский институт», созданный в 1943 г. как секретная Лаборатория № 2, в настоящее время стал крупнейшей национальной научной лабораторией России и одним из ведущих мировых центров науки. Курчатовскому институту принадлежит ключевая роль в обеспечении безопасности страны и развитии важнейших стратегических направлений науки, включая разработку и создание ядерного оружия, атомного подводного и надводного флотов, атомной энергетики страны.

Именно в Курчатовском институте, стоявшем у истоков великого советского атомного проекта, одновременно с ядерной физикой развивалась опальная долгие годы генетика, медицинские технологии, сверхпроводимость, информационные системы, отсюда вышел Рунет. Ещё в 1940-50-е гг. в Институте развернулись радиационно-биологические исследования, а после разгрома отечественной генетики, И.В. Курчатов и его ближайший соратник А.П. Александров по собственной инициативе, в рамках медико-биологического подразделения продолжили генетические исследования. Так был образован Радиобиологический отдел со специальным Сектором генетики и селекции микроорганизмов под руководством С.И. Алиханяна.

В 1960 г. Институту атомной энергии было присвоено имя его основателя - Игоря Васильевича Курчатова. В 1991 г. Институт получил статус Российского научного центра, а в 2010 г. стал первым в стране Национальным исследовательским центром. В 1999 г. в Институте был пущен единственный на постсоветском пространстве специализированный источник синхротронного излучения «КИСИ - Курчатов», в 2009 г. создан первый в мире Центр конвергентных нано-, био-, информационных, когнитивных и социогуманитарных наук и технологий.

Современный Курчатовский институт является одним из ведущих научных центров мира. Со дня основания в Институте развивается междисциплинарный подход, нацеленный на полный цикл - от фундаментальных исследований до конечных технологий. В последнее десятилетие в Курчатовском институте формируются научные основы природоподобного технологического уклада. Здесь проводятся исследования по самым разным направлениям - от термоядерной энергетики и физики элементарных частиц до природоподобных НБИКС-технологий.

В структуру современного Курчатовского института входят девять ведущих научных организаций страны: Институт физики высоких энергий, Институт теоретической и экспериментальной физики, Петербургский институт ядерной физики, Центральный научно-исследовательский институт конструкционных материалов «Прометей», Научно-исследовательский институт химических реактивов и особо чистых химических веществ, Питомник лабораторных животных Рапполово, Институт физических проблем, а также Государственный научно-исследовательский институт генетики и селекции промышленных микроорганизмов и Институт молекулярной генетики. В 2019 г. на базе Курчатовского института создан центр геномных исследований «Курчатовский геномный центр».

Сегодня основными задачами Курчатовского института являются:

- создание междисциплинарного научного задела, обеспечивающего прорыв по приоритетным направлениям научно-технологического развития страны;

- технологическое освоение созданного научного задела и вовлечение в хозяйственный оборот результатов интеллектуальной деятельности; 
- модернизация, эксплуатация и создание принципиально новых мегаустановок мирового класса;

- развитие международного научного сотрудничества.

Исследовательско-технологическая база Курчатовского института включает 47 уникальных научных установок класса мегасайенс и комплексов, среди которых: специализированный источник синхротронного излучения; источники нейтронов, включая самый мощный в мире реакторный комплекс ПИк; суперкомпьютерный центр моделирования и обработки данных; уникальный комплекс биологических моделей; комплекс нейрокогнитивных и социогуманитарных технологий; комплекс технологий ядерной медицины и лучевой терапии; комплекс белковой кристаллографии; комплекс геномики, биоинформатики, синтетических биологических структур; комплекс гибридных материалов, структур, устройств и систем (микроэлектромеханические и наноэлектромеханические системы); комплекс сверхпроводимости; комплекс инновационной энергетики и др.

В Курчатовском институте работает более 12000 сотрудников, более трети из них - это молодые специалисты, выпускники базовых кафедр и партнерских университетов. Курчатовский институт, имеющий уникальный научный, технологический и кадровый потенциал, проводит работу по обучению и привлечению к исследованиям талантливых молодых специалистов. Система подготовки кадров основана на принципе непрерывности и междисциплинарности, который закладывается в средней школе, развивается на этапе бакалавриата и закрепляется в магистратуре и аспирантуре. Широкомасштабная работа по целевой междисциплинарной подготовке научных и инженерных кадров осуществляется в рамках крупных базовых образовательных структур Курчатовского института: ИНБИКСТ МФТИ и физического факультета Санкт-Петербургского государственного университета, а также более чем на 20 базовых и партнерских кафедр ведущих университетов Москвы и Санкт-Петербурга.

123182, Россия, Москва, пл. Академика Курчатова, д. 1

Телефон: +7 (499) 196-95-39 Факс: +7 (499) 196-17-04

Сайт: nrcki.ru

Электронная почта: nrcki@nrcki.ru

\section{ИЦиГ СО РАН, НовОСибирсК}

Директор - чл.-кор. РАН Алексей Владимирович Кочетов

Ученый секретарь - Галина Владимировна Орлова, кандидат биологических наук тел.: +7(383) 363-49-85, доп. 1336, e-mail: OrlovaGV@icg.sbras.ru, gorlova@bionet.nsc.ru

Институт создан в 1957 г. в числе первых институтов Сибирского отделения АН СССР. В настоящее время ИЦиГ СО РАН - мультидисциплинарный, многопрофильный биологический институт, который по праву считается одним из ведущих научных учреждений биологического профиля в России. В мае 2017 г. закончился второй этап реорганизации Федерального исследовательского центра Институт цитологии и генетики Сибирского отделения РАН. На сегодняшний день ФИЦ включает три филиала:

- Сибирский научно-исследовательский институт растениеводства и селекции (СИБНИИРС),

- Научно-исследовательский институт клинической и экспериментальной лимфологии (НИИКЭЛ),

- Научно-исследовательский институт терапии и профилактической медицины (НИИТПМ).

Миссия ИЦиГ СО РАН. Решение приоритетных задач развития научно-технологического комплекса РФ в области генетики и селекции растений, генетики и селекции животных, генетики человека и биотехнологии на основе методов молекулярной генетики, клеточной биологии и биоинформатики.

Стратегическая задача. Проведение полных циклов исследований от генерации фундаментальных знаний до прикладных разработок в области генетики и селекции растений, генетики и селек- 
ции животных, генетики человека и биотехнологии на основе методов молекулярной генетики, клеточной биологии и биоинформатики, имеющих приоритетное значение для решения задач агропромышленного, биотехнологического, медико-биологического и фармацевтического комплексов России.

Кадровый состав. На 1 июня 2020 г. в ФИЦ ИЦиГ СО РАН 120 научных подразделений, в которых работает 1436 человек, в том числе 548 научных сотрудников, 2 советника РАН, 7 академиков РАН, 5 членов-корреспондентов РАН, 94 доктора наук, 316 кандидатов наук.

Аспирантура. На 1 июня 2020 г. в аспирантуре ФИЦ ИЦиГ СО РАН обучается 60 аспирантов.

Публикации. Институт активно печатается в российских и зарубежных журналах и является в российской биологии одним из признанных лидеров. Общее количество статей в рецензируемых журналах в 2019 году составило 530. В 2015-2019 гг. статьи сотрудников института цитировались в WoS 12362 раза.

СМИ: ИЦиГ СО РАН является учредителем следующих СМИ: «Вавиловский журнал генетики и селекции», «Атеросклероз», «Сибирский научно-медицинский журнал», «Письма в Вавиловский журнал генетики и селекции» и «Живая наука».

Инфраструктура ИЦиГ СО РАН. УНУ «Центр генетических ресурсов лабораторных животных (ЦГР)» и семь центров коллективного пользования (http://www.bionet.nsc.ru/uslugi/).

Имущественный комплекс. Земельный участок площадью 35 тыс. га, закрепленный на праве постоянного пользования; 85 тыс. м² рабочих площадей, расположенных на территории Советского района г. Новосибирска, Барышевского сельского совета Новосибирской области, в Искитимском и Черепановском районах НСО, в пос. Краснообск Новосибирской области.

Федеральный исследовательский центр ИЦиГ СО РАН приглашает к сотрудничеству научные и коммерческие организации!

Адрес: 630090, Россия, Новосибирск, проспект Академика Лаврентьева, 10

тел./факс: +7(383) 363-49-80/+7(383) 333-12-78

URL: www.bionet.nsc.ru e-mail: icg-dm@bionet.nsc.ru

\section{ФГБУН «НБС - ННЦ», Ялта}

Директор - член-корреспондент РАН Юрий Владимирович Плугатарь

Ученый секретарь - Татьяна Сергеевна Науменко, кандидат сельскохозяйственных наук

тел. +7(3654) 250098, e-mail: uchenysekretarnbg@mail.ru; uch.sekretar@nbgnsc.ru

Никитский ботанический сад основан в 1812 г. и с первых дней существования способствовал ускоренному развитию сельскохозяйственного производства юга России на основе интродукции, акклиматизации, селекции и широкого распространения плодовых, цветочных, декоративных, эфиромасличных, лекарственных и других полезных растений, изучения и активного использования местных растительных ресурсов. В 1962 г. Государственный Никитский ботанический сад удостоен ордена Трудового Красного Знамени. В 1995 г. в честь Сада была названа малая планета в поясе астероидов за номером 4480 - «Никитиботания».

Родоначальник отраслей и институтов. Никитский ботанический сад - родоначальник таких отраслей народного хозяйства России, как виноградарство, эфиромасличное растениеводство, табаководство, южное декоративное садоводство, южное и субтропическое плодоводство. На базе Сада получили жизнь такие известные отраслевые институты, как Институт винограда и вина «Магарач», Институт эфиромасличных и лекарственных растений, опытные станции овощебахчевых и лекарственных растений, табаководства. Никитское училище садоводства стало самостоятельным техникумом (ныне - Крымский агропромышленный колледж). 
Кадровый состав. На 1 июня 2020 г. в ФГБУН «НБС-ННЦ» работает 767 человек, в том числе 159 научных сотрудников, 2 члена-корреспондента РАН, 20 докторов наук, 54 кандидата наук.

Аспирантура. На 1 июня 2020 г. в аспирантуре ФГБУН «НБС-ННЦ» обучается 33 аспиранта по специальностям «ботаника», «экология», «селекция и семеноводство сельскохозяйственных растений».

Публикации. Институт активно печатается в российских и зарубежных журналах. Общее количество статей в рецензируемых журналах в 2019 году составило 411. В 2015-2019 гг. опубликовано 238 статей в WoS и Scopus.

СМИ: ФГБУН «НБС-ННЦ» является учредителем следующих СМИ: «Бюллетень Государственного Никитского ботанического сада», «Биология растений и садоводство: теория, инновации», «Научные записки природного заповедника «Мыс Мартьян».

Инфраструктура: ОИ «Коллекционный фонд Федерального государственного бюджетного учреждения науки «Ордена Трудового Красного Знамени Никитский ботанический сад - Национальный научный центр РАН», «УНУ ««Научный центр биотехнологии, геномики и депонирования растений (УНУ «Фитобиоген»), ЦКП «Физиолого-биохимические исследования растительных объектов».

Крупнейшее в России хранилище плодовых культур и коллекций. Сад является крупнейшим в нашей стране хранилищем видового и сортового разнообразия южных плодовых культур, включающего более 11000 сортов персика, абрикоса, алычи, черешни, яблони, груши, айвы, инжира, граната, маслины, зизифуса, хурмы и других культур. Здесь собраны уникальные коллекции декоративных древесных и травянистых растений, насчитывающие более 6000 видов, и богатейшие сортовые и формовые коллекции более 350 ботанических видов эфиромасличных, лекарственных, пряно-ароматических растений. Впервые введено в культуру более 400 видов новых растений, создано более 800 сортов культурных растений.

Памятник садово-паркового искусства. Всемирную известность принес Саду его уникальный Арборетум (дендрарий). На площади более 40 га сосредоточены коллекции древесных растений мировой флоры. В парках Арборетума представлено свыше 2000 видов деревьев и кустарников. Никитский ботанический сад как памятник садово-паркового искусства является живым музеем и зеленой сокровищницей под открытым небом. Один из интереснейших туристических объектов - Государственный природный заповедник «Мыс Мартьян», входящий в состав Никитского ботанического сада.

Приглашаем вас в оазис красоты и гармонии, вечно юный двухсотлетний сад! Уверены, что вы полюбите наш сад так же, как любим его мы.

Адрес: 298648, Россия, Республика Крым, Ялта, пгт Никита

тел.: +7 (3654) 33-55-30, e-mail: priemnaya-nbs-nnc@ya.ru

http://nbgnsc.ru; http://nikitasad.ru

ФГАОУ ВО «Севастопольский государственный университет», Севастополь

Ректор, доктор политических наук, профессор Владимир Дмитриевич Нечаев

Учёный секретарь - Светлана Петровна Строкина, тел.: +7 (8692) 41-77-41

e-mail: SPStrokina@sevsu.ru

История. В 1963 г. Севастопольский филиал Одесского политехнического института (СФОПИ) был преобразован в Севастопольский приборостроительный институт (СПИ). В 1994 г. институт получил статус государственного университета и был переименован в Севастопольский государственный технический университет (СевГТУ). 8 ноября 2001 г. указом Президента Украины Леонида Даниловича Кучмы Севастопольский государственный технический университет переименован в Севастопольский национальный технический университет (СевНТУ). 8 октября 2014 г. премьер- 
министр России Дмитрий Медведев подписал распоряжение о создании Севастопольского государственного университета.

За 46 лет вуз прошел путь становления, развития, получил самый высокий (четвертый) уровень аккредитации с полным объемом прав. Открыты новые специальности, охватывающие наиболее перспективные образовательно-профессиональные направления. Все специальности подкреплены лицензиями Государственной аттестационной комиссии. Университет размещен в шести учебных корпусах (площадью 59 тыс. м²) с оборудованными специализированными лабораториями, учебными аудиториями, музеем, центром компьютерных технологий, проблемными лабораториями, библиотекой с книжным фондом свыше миллиона томов, корпусами общежитий, современным спортивным комплексом.

Кадровый потенциал. Преподавательский корпус составляют 47 докторов наук и профессоров, 233 доцента и кандидата наук. Численность студентов составляет более 11 тысяч человек.

Основная деятельность университета. Осуществление образовательной деятельности по программам высшего образования и научной деятельности. СевГУ проводит обучение студентов по квалификационным уровням: бакалавр, специалист, магистр, а также готовит специалистов среднего профессионального образования. В университет входят 12 институтов, колледж и военный учебный центр:

- Институт информационных технологий и управления в технических системах

- Институт общественных наук и международных отношений

- Институт Национальной технологической инициативы

- Институт ядерной энергии и промышленности

- Институт общественных наук и международных отношений

- Морской институт

- Институт радиоэлектроники и информационной безопасности

- Институт развития города

- Институт финансов, экономики и управления

- Политехнический институт

- Гуманитарно-педагогический институт

- Юридический институт

- Морской колледж

- Военный учебный центр

Адрес: 299053, Россия, г. Севастополь, ул. Университетская, 33

https://www.sevsu.ru/ 

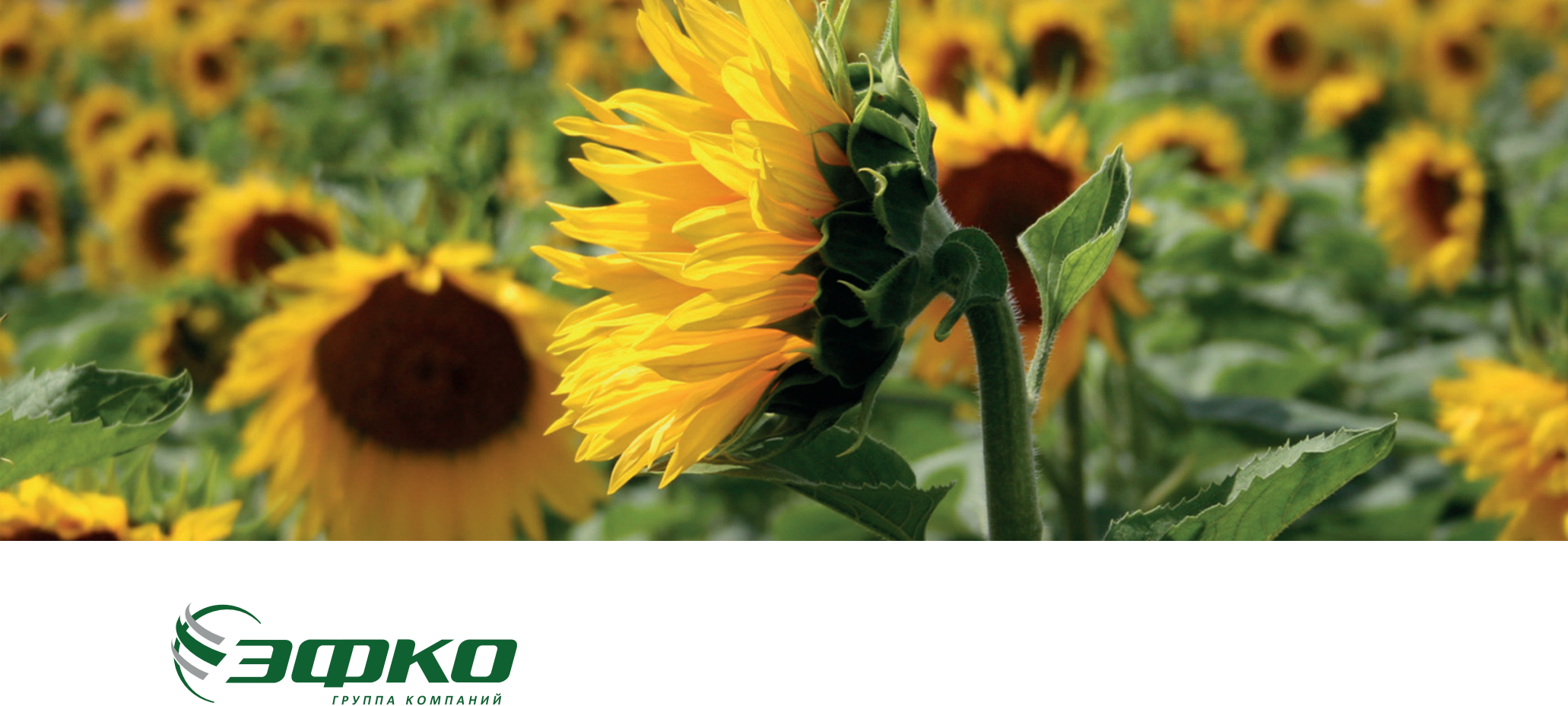

Группа Компаний «ЭФКО» - вертикально интегрированный холдинг, входящий в число крупнейших предприятий пищевой промышленности России, обеспечивающих продовольственную безопасность страны. ГК «ЭФКО» Входит в число системообразующих предприятий на территории РФ и лидирует на рынке пищевых ингредиентов, используемых в кондитерской, хлебопекарной и других отраслях. Компания занимает передовые позиции на рынке переработки масличных и в поставках белковых компонентов комбикормов.

ГК «ЭФКО» является одним из ведущих производителей растительного масла, майонеза, кетчупа и кисломолочной продукции. Потребительские товары компании выпускаются под широко известными торговыми марками «Слобода» и «Altero», которые неоднократно отмечались Государственным знаком Качества. Подсолнечные масла Компании экспортируются более чем в 50 стран мира.

Инновационная деятельность является одним из ключевых драйверов развития ГК «ЭФКО», а также обеспечивает лидерство Компании внутри страны и на мировом рынке. Именно собственные инновационные проекты позволили ГК «ЭФКО» занять ведущее положение в различных направлениях бизнеса: в области переработки сырья, производства высокотехнологичных жиров и брендовой продукции. В каждом дивизионе Компании созданы исследовательские лаборатории и центры прикладных исследований, которые занимаются разработкой и тестированием жировых продуктов для линий здорового питания и инновационных рецептур с учетом потребностей производителей пищевой отрасли.

В 2016 году для решения актуальных исследовательских задач для уже существующих и новых направлений бизнеса был создан ООО «Инновационный Центр «Бирюч - новые технологии», фокус исследований которого сосредоточен на таких перспективных направлениях, как олеохимия, современные биотехнологии, включая биокатализ, генетические исследования, производство инновационных продуктов питания, глубокая переработки сельскохозяйственного сырья, повышения эффективности животноводства и птицеводства.

ГК «ЭФКО» уделяет особое внимание сотрудничеству с ведущими научно-исследовательскими институтами, а также ведет активную работу с профильными вузами, акселераторами стартап-проектов и поддерживает конкурсы научных идей. 


\section{ФИТОСКРИН}

\section{технология быстрой молекулярно-генетической диагностики заболеваний растений методом ПЦР в реальном времени}

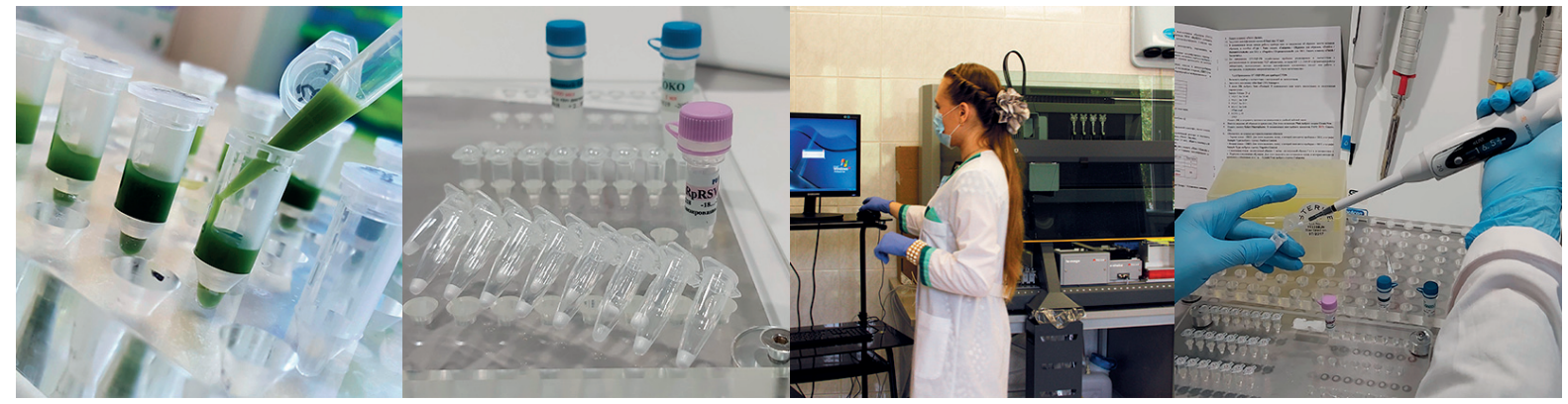

обнаружение ДНК/ РНК фитопатогенов происходит с высокой точностью и достоверностью

- специфичность наборов близка к 100\%, подтверждена в ходе испытаний на широкой выборке коллекционных близкородственных и сопутствующих искомому возбудителю организмов (использовались коллекции ВКМ, ВКПМ, ФГБУ «ВНИИКР», DSMZ, CFBP)

- чувствительность наборов реагентов: для бактерий - не более 3 × $10^{3} \mathrm{KOE} /$ мл образца, для вирусов - до 6 порядков разведения РНК, выделенной из растения со средней степенью заражённости

- процесс выделения ДНК может быть автоматизирован с помощью роботизированной станции Freedom EVO (TECAN), что позволяет увеличить производительность лаборатории, уменьшить трудозатраты, снизить риск контаминации

च при анализе РНК-содержащих вирусов реакция обратной транскрипции и ПЦР совмещены, что экономит время оператора и уменьшает трудоёмкость анализа

- наборы реагентов «ФИТОСКРИН» адаптированы к наиболее распространённым в России real-time амплификаторам: CFX96, «ДТпрайм», «ДТлайт», Rotor-Gene Q/ 6000, «АНК»
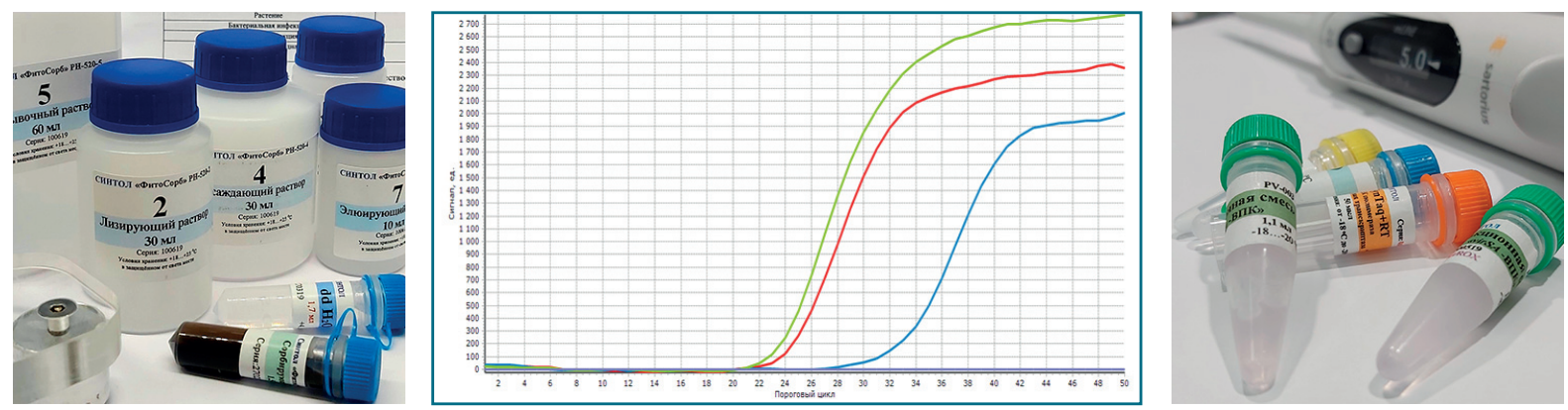

\section{ГССНТОЛ}

научно-производственная компания

000 «СИНТОЛ», 127550, Москва, Тимирязевская, 42, Тел. (495) 984-69-93, infođsyntol.ru, www.syntol.ru 


\section{Biolabmix}

\section{Мы делаем ПЦР проще и удобнее}

ООО «Биолабмикс»- научно-производственная компания, основанная в 2010 г в новосибирском Академгородке. Мы являемся разработчиками и производителями собственной инновационной, качественной и конкурентоспособной продукции.

Миссия нашей компании - создание комфортных условий для работы российских исследователей.

Наборы для ПЦР длинных фрагментов ДНК

Наборы для ПЦР в режиме реального времени с SYBR Green I

Наборы для ПЦР в режиме реального времени с флуоресцентными зондами

Наборы для классической ПЦР

Маркеры молекулярных весов ДНК ready-to-use

Наборы и реагенты для выделения нуклеиновых кислот

Модифицированные (16) и стандартные (15) дезокси- и рибо- нуклеозидтрифоссраты (dNTP/NTP), дидезоксинуклеозидтрифоссраты (5) ddNTP, фрерменты для молекулярной биологии (8), аффинноочищенные антитела (АфАТ) (16) ,иммуносорбенты (5), конъюгаты с пероксидазой из хрена и биотином, моноклональные антитела см.biosannsk.ru

biolabmix.ru

630090, Новосибирск, ул. Инженерная, 28

svt@biolabmix.ru

+7 983-308-75-08 


\section{Биохимические реактивы, оборудование}

и расходные материалы Life Sciences

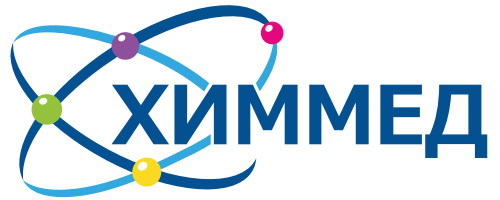

www.chimmed.ru

\section{Исследования в биотехнологии:}

\section{- клеточные культуры}

- секвенйрование енома

q профилирование эксирессий PH

O kIMP

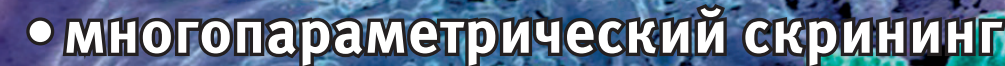

onporounar quтометрия

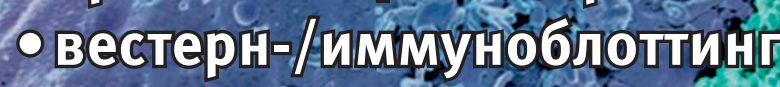

о профилтровайе киназ?
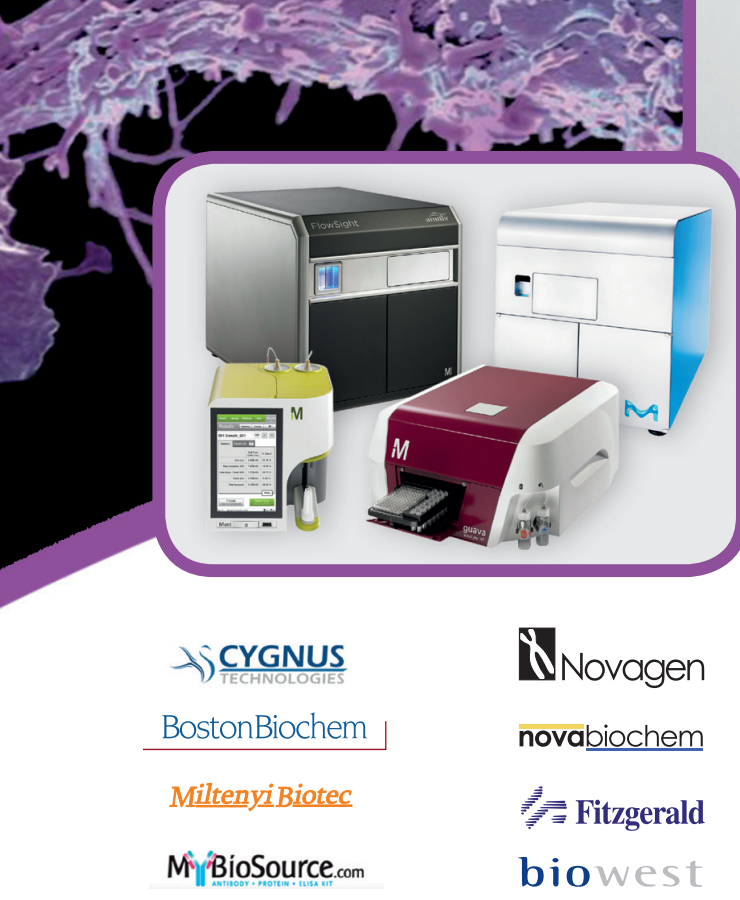

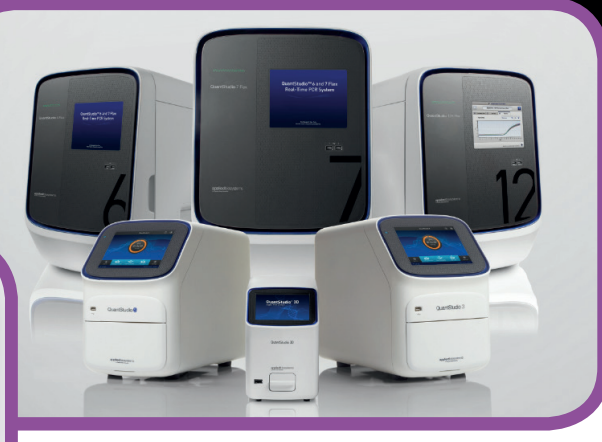

EEnzo $\quad$ biotechne

RDSYSTEMs

TOCRIS

MERCK

CORNING

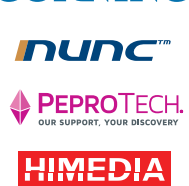

$$
\begin{aligned}
& \text { SfNOVIOLG SIS } \\
& \text { a biotechne brand }
\end{aligned}
$$

r-biopharm

Abnova

AbD Serotec
ThermoFisher S C I E N T I F I C invitrogen thermo gibco scientific gythemo is iontorrent applied blosystems

8088 QIAGEN NEOF ROXX Roche Ouvantio Promega

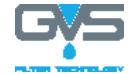

Мы можем предоставить демоверсии приборов в вашу лабораторию!

Москва, 115230, Каширское шоссе, д. 9, корп. 3. Тел.: +7 (495) 728 4192, e-mail: bio@chimmed.ru Санкт-Петербург, 195248, просп. Энергетиков, д. 19, оф. 314. Тел.: +7 (812)605 0061, e-mail: spb@chimmed.ru Казань, 420081, ул. Седова, д. 22. Тел.: +7 (843) 273 6761, 272 9786, e-mail: kazan@chimmed.ru Новосибирск, 630090, просп. Академика Лаврентьева, 6/1. Тел.: +7 (383) 335 6108, e-mail: sibir@chimmed.ru 


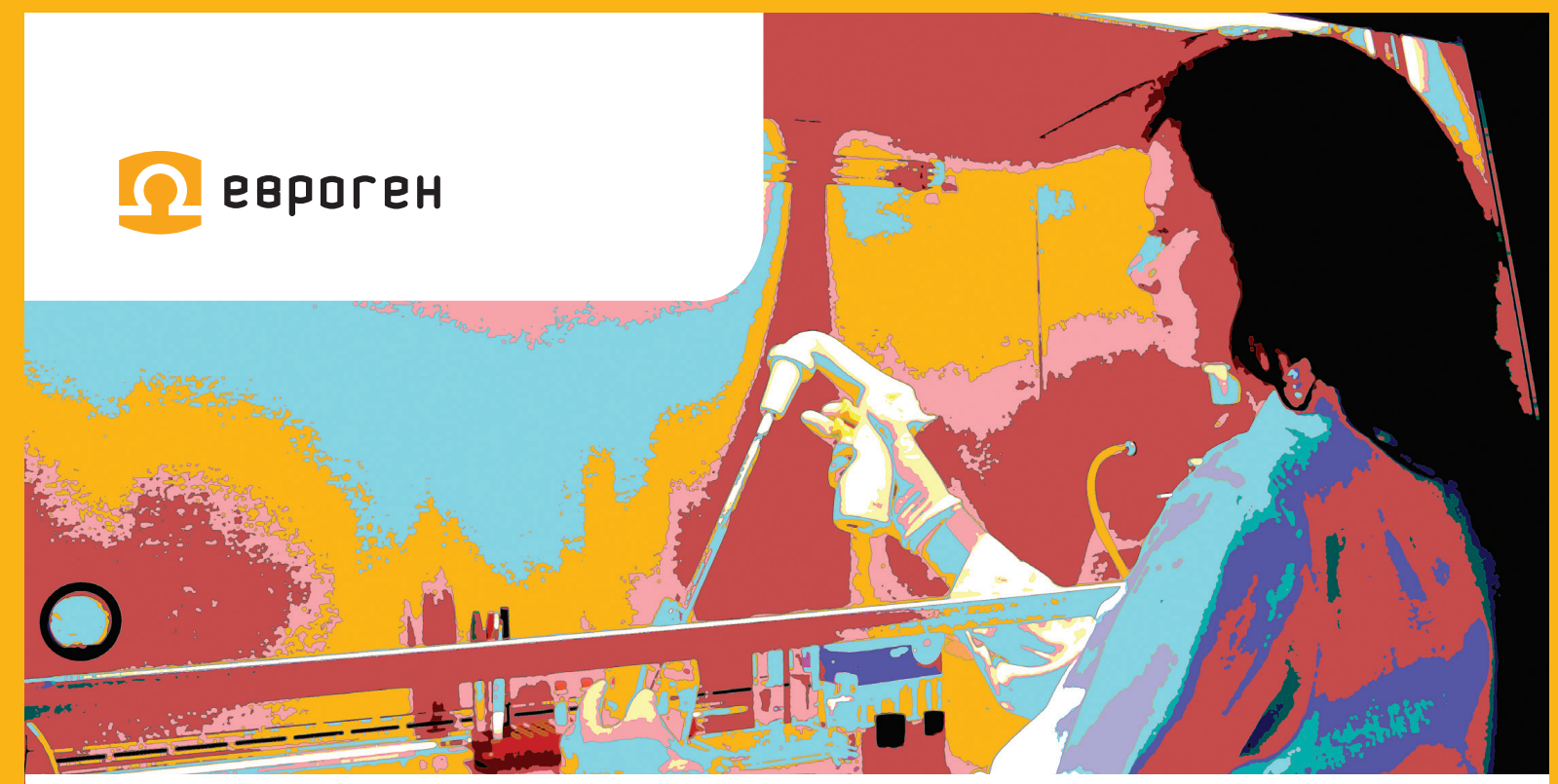

\section{ЕВРОГЕН}

Российская биотехнологическая компания, основанная в 2000 г.

Свою историю компания начала с разработок в области флуоресцентных технологий.

Первым успехом было открытие семейства флуоресцентных белков, которые уже более 20 лет востребованы как в России, так и за рубежом.

На сегодняшний день компания предлагает не только уникальные разработки, но и решения, широко используемые для выполнения рутинных задач.

Реактивы и наборы реагентов предназначены для решения задач:

- Фиксация клеточной РНК;

- Выделение и очистка нуклеиновых кислот;

- Оценка концентрации и качества ДНК;

- Постановка ПЦР и ПЦР-РВ (полимеразы и готовые смеси);
- РаботаскднК (синтез, амплификация, нормализация);

- Клонирование ДнК;

- Клеточная биология;

- Практикум по генной инженерии (обучающий набор для студентов).

\section{Сервисные работы выполняются по направлениям:}

- Секвенирование по Сэнгеру;

- NGS-секвенирование;

- Генная инженерия (синтез генов, мутагенез, клонирование);
- Синтез олигонуклеотидов;

- Клеточные технологии (конструирование лентивирусов, трансфекция культур клеток).

Компания Евроген | www.evrogen.ru | Россия, г. Москва, ул. Миклухо-Маклая д. $16 / 10$

+7 (495) 988-40-83 | order@evrogen.ru 


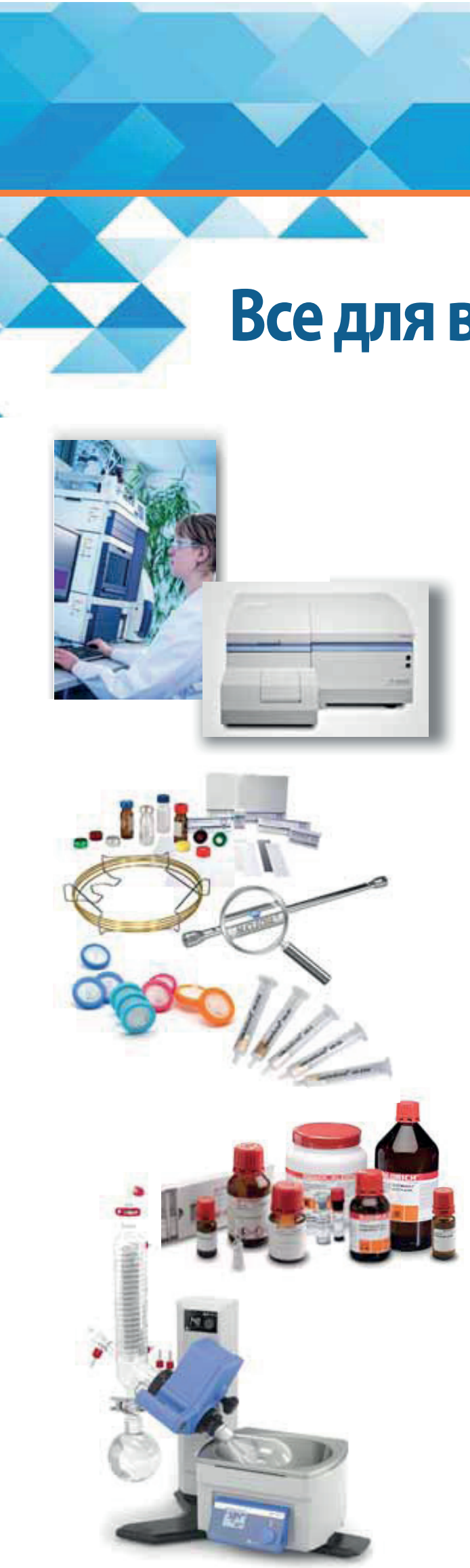

ГАААХИМ www.galachem.su mailbox@galachem.su

\section{Все для вашей лаборатории!}

Аналитические приборы

- ВЭЖХ и УВЭЖХ Hitachi Chromaster

- Хромато-масс-спектрометры

- Препаративные хроматографы PuriFlash

- Спектрофотометры и спектрофлуориметры

Все для хроматографии

Колонки для ГХ и ВЭЖХ, растворители, сорбенты, виалы, крышки, шприцевые фильтры

\section{Лабораторное оборудование} и расходные материалы

- Проточные реакторы, мешалки, насосы, сушильные шкафы, центрифуги, испарители

- Лабораторное стекло и пластик

\section{Реактивы и стандартные образцы}

- Реактивы производства Sigma-Aldrich, Merck, ABCR, Alfa-Aesar, ChemPure, Fluorochem, J\&K

- Аналитические стандарты Supelco, Dr. Ehrenstorfer

- Фармакопейные стандарты USP, LGC Standarts

\section{www.galachem.su}




\section{MERCK}

\section{nPOMO ПРЕДЛОККЕНИЕ}

HA НАБОРЫ MILLIPLEX ${ }^{\oplus}$ НА 2020 ГОД

MILLIPLEX MAP

Multiplex Assays
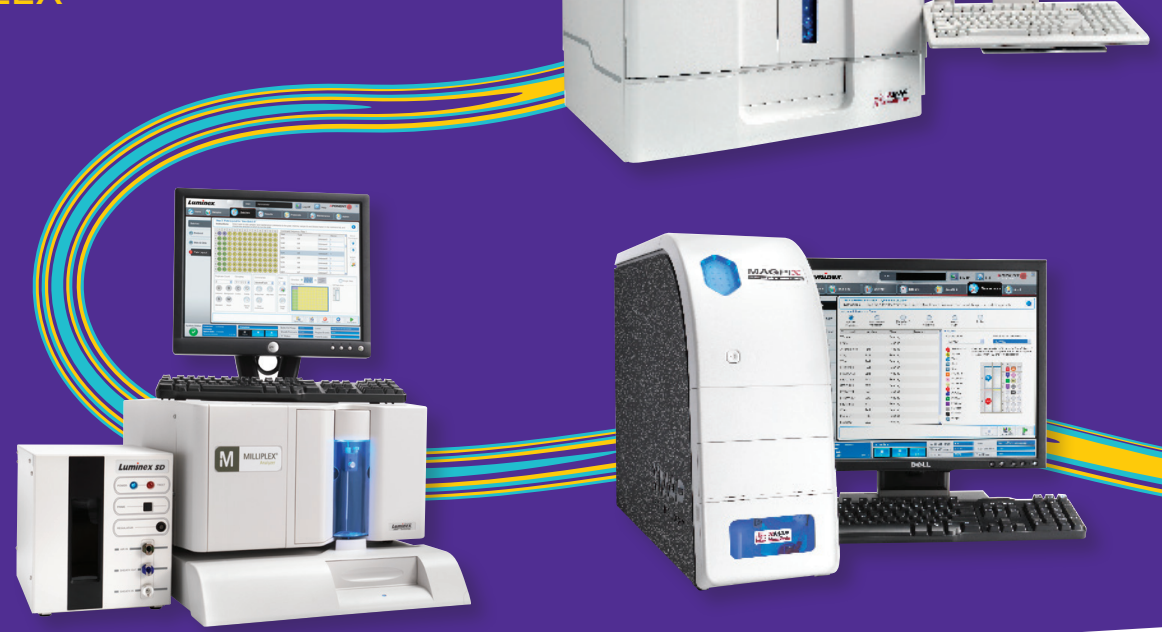

$-4 \%$.

\begin{tabular}{|c|c|c|}
\hline Каталожный № & Наименование и описание & Цена/ед. , рублей \\
\hline HCYTA-60K-PX48 & $\begin{array}{l}\text { Human Cytokine/Chemokine/Growth Factor Panel A, } 48 \text { plex kit } \\
\text { sCD40L, EGF, Eotaxin, FGF-2, FLT-3L, Fractalkine, G-CSF, GM-CSF, GROa, } \\
\text { IFNa2, IFNy, IL-1a, IL-1 } 13 \text {, IL-1RA, IL-2, IL-3, IL-4, IL-5, IL-6, IL-7, IL-8, IL-9, IL-10, IL- } \\
12 \text { (p40), IL-12 (p70), IL-13, IL-15, IL-17A, IL-17E/IL-25, IL-17F, IL-18, IL-22, IL-27, } \\
\text { IP-10, MCP-1, MCP-3, M-CSF, MDC, MIG, MIP-1a, MIP-1 } \beta \text {, PDGF-AA, PDGF-AB/ } \\
\text { BB, *RANTES, TGFa, TNFa, TNF } \beta \text {, VEGF-A }\end{array}$ & 303000 \\
\hline HCYTMAG-60K-PX41 & $\begin{array}{l}\text { Human Cytokine/Chemokine Panel I, } 41 \text { plex ki } \\
\text { EGF, Eotaxin, G-CSF, GM-CSF, IFNa2, IFN } 1 \text {, IL-10, IL-12P40, IL-12P70, IL-13, IL- } \\
\text { 15, IL-17A, IL-1RA, IL-1a, IL-1 } \beta \text {, IL-2, IL-3, IL-4, IL-5, IL-6, IL-7, IL-8, IP-10, MCP-1, } \\
\text { MIP-1a, MIP-1 } \beta \text {, RANTES, TNFa, TNF } \beta \text {, VEGF,FGF-2, TGF-a, FIT-3L, Fractalkine, } \\
\text { GRO, MCP-3, MDC, PDGF-AA, PDGF-AB/BB, SCD40L, IL-9 }\end{array}$ & 265000 \\
\hline HSTCMAG28SPMX21 & $\begin{array}{l}\text { Human High Sensitivity T Cell, } 21 \text { plex kit } \\
\text { Fractalkine, GM-CSF, IFNy, IL-1 } \beta \text {, IL-2, IL-4, IL-5, IL-6, IL-7, IL-8, IL-10, IL-12 (p70), } \\
\text { IL-13, IL-17A, IL-21, IL-23, ITAC, MIP-1 } a \text {, MIP-1 } \beta \text {, MIP-3a and TNFa }\end{array}$ & 165000 \\
\hline HCVD1MAG-67K-12 & $\begin{array}{l}\text { Human CVD Panel 1, } 12 \text { analytes kit } \\
\text { BNP, NTproBNP, CK-MB, CXCL6, CXCL16, Endocan-1 (ESM-1), FABP3, FABP4, } \\
\text { LIGHT, Oncostatin-M (OSM), Placental Growth Factor (PIGF), and Troponin I }\end{array}$ & 115000 \\
\hline HCCBP1MAG-58K-24 & $\begin{array}{l}\text { Human Circulating Cancer Biomarker Panel } 1 \\
\text { a-Fetoprotein (AFP), CA125, CA15-3, CA19-9, CEA, CYFRA21-1, sFAS/ } \\
\text { TNFRSF6, sFasL, FGF-2/FGF-basic, HCG } 3 \text {, HE4, HGF, VEGF-A, IL-6, IL-8/CXCL8, } \\
\text { Leptin, MIF, Osteopontin (OPN), Prolactin, PSA (free) /PSA (total), SCF, TGFa, } \\
\text { TNFa, TRAIL/TNFSF10 }\end{array}$ & 186000 \\
\hline
\end{tabular}
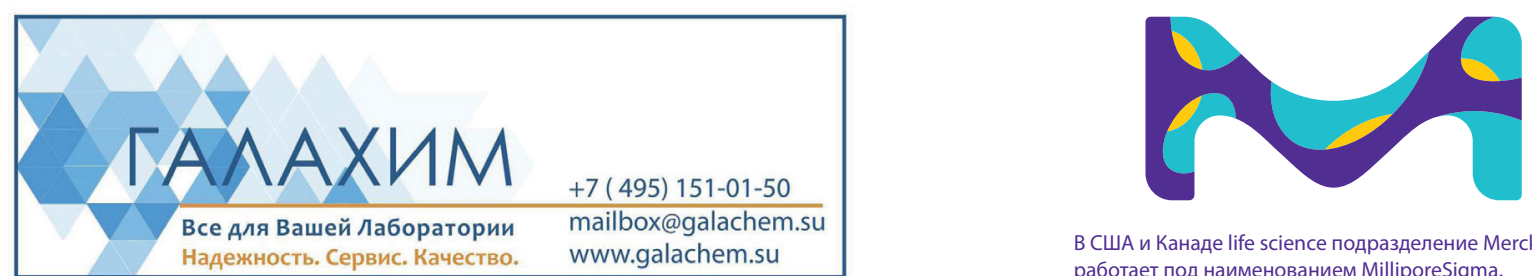

В США и Канаде life science подразделение Merck работает под наименованием MilliporeSigma. 


\section{Milli-Q \\ Lab Water Solutions \\ СИСТЕМЫ ОЧИСТКИ ВОДЫ Milli-Q ${ }^{\circledR}$}

MerCK

Основные преимущества:

- высокое качество

- удобство пользования

- надёжность

- прогнозируемая замена расходных материалов

- высокий КПД обратного осмоса

- сертификаты калибровки на все датчики и мониторы

- доступность

- со склада в Москве

Системы получения сверхчистой воды (тип I)

Milli-Q ${ }^{\circledR} I Q 7000$

Milli- $Q^{\circledR}$ Reference

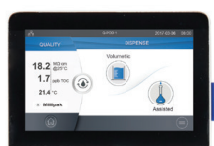

Super- $Q^{\circledR}$

Simplicity ${ }^{\circledR}$

Системы получения сверхчистой воды (тип II)

RiOs-Di

Elix ${ }^{\circledast}$ Advantage, Elix ${ }^{\circledast}$ Essential

Milli-Q ${ }^{\circledR}$ HX 7000, Milli-Q HX 7000 SD

(высокопроизводительные системы до 9000 л/день)

Системы получения сверхчистой воды (тип III)

$\mathrm{RiOs}^{\mathrm{TM}}$ Essential

Milli-Q ${ }^{\circledR}$ HR 7000

Комбинированные системы очистки воды Milli-Q ${ }^{\circledR}$ Direct 8/16

Milli-Q ${ }^{\circledR}$ IQ 7003/5/10/15

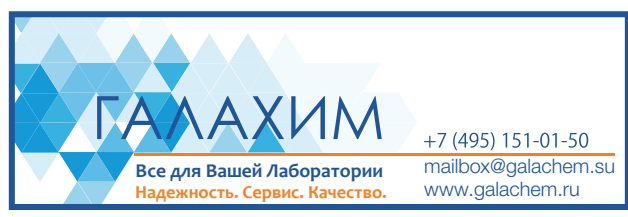




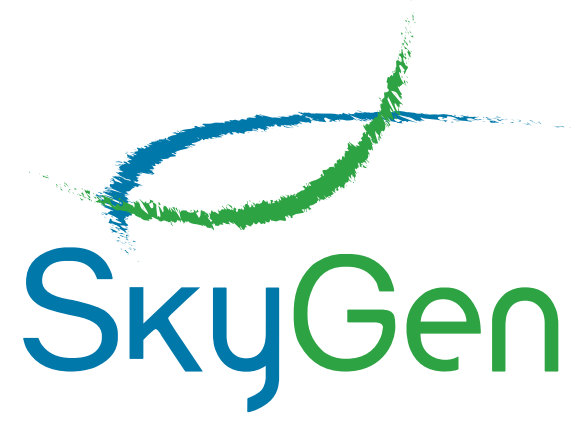

Мы находим, разрабатываем и внедряем высокотехнологичные решения в генетике и геномике.

Наша цель - успех исследований наших покупателей.

Мы поставляем оборудование, реагенты и расходные материалы для исследовательских и биотехнологических лабораторий и производств.

В настоящее время мы являемся эксклюзивным дистрибьютером продукции компаний $\mathrm{New}$ England Biolabs, 10x Genomics, Nimagen, Bio Molecular Systems и официальным дистрибьютером продукции компаний QIAGEN, Agilent Technologies, Oxford Nanopore Technologies, BioSan, Sigma-Aldrich, Thermo Fisher Scientific.

\section{5 ПРИЧИН ВЫБРАТЬ SKYGEN}

- Доступ к высококачественной продукции

- Быстрая логистика и складская программа

- Удобное и взаимовыгодное сотрудничеСТВО

- Высококвалифицированная научная и сервисная поддержка

- Адекватные цены и надежность

Команда SkyGen никогда не останавливается в своем развитии и отслеживает все новые научные тенденции, чтобы предлагать вам самые передовые технологии и решения.

Нас знают.

Нам доверяют.

Нас рекомендуют.

ООО «СкайДжин», 115093, Москва, ул. Люсиновская, д. 36, стр. 1 (БЦ «Гласс Хаус»), 6 этаж, офис 6.4

Телефон: 8 (495) 215-02-22

Бесплатная горячая линия: 8 (800) 333-12-26

Электронная почта: info@skygen.com

Сайт: www.skygen.com
SKYGEN

THE LIFE SCIENCE

TRADE \& SERVICES COMPANY

SkyGen LLC is a Russian \& CIS life science distributor company totally committed to supporting life science researchers. We are currently an exclusive product distributor of New England Biolabs, 10x Genomics, Nimagen, Bio Molecular Systems and an official product distributor of QIAGEN, Agilent Technologies, Oxford Nanopore Technologies, BioSan, Sigma-Aldrich, Thermo Fisher Scientific.

Founded in 2012, SkyGen was established from a vision to improve the Russian \& CIS researcher experience by making researchers' jobs easier and more efficient, celebrating their research successes and standing up for their needs.

For more than 6 years we have been providing more than 3000 Russian and CIS labs with plenty of life science equipment and reagents. Our customers are leading research scientists both in Russian \& CIS universities, hospitals, biotechnology companies, pharmaceutical companies and accredited laboratories.

We search, develop and implement new modern solutions in molecular biology. We believe being a researcher is a valuable contribution to the community, and it is a challenging field to work in. It is our mission to provide you with more personalised support, greater choice of products, to calibrate and verify your measuring means, validate clean rooms and to organize reagents \& consumables delivery as fast as possible.

We are known. We are trusted. We are recommended.

\section{SkyGen LLC}

Lyusinivskaya str., 36, building 1, 115093,

Moscow, Russia

+7 (495) 215-02-22

+7 (800) 333-12-26

info@skygen.com

www.skygen.com 


\title{
A comparative analysis of the metaphase chromosomes of Aedes excrucians, Ae. behningi, Ae. intudens and Ae. punctor mosquitoes species (Diptera: Culicidae) in Tomsk region
}

\author{
Alekseeva S.S. ${ }^{1,2 *}$, Andreeva Yu.V. ${ }^{1}$, Wasserlauf I.E. ${ }^{1}$, Sibataev A.K. ${ }^{1}$, Stegniy V.N. ${ }^{1}$ \\ ${ }^{1}$ Tomsk State University, Tomsk, Russia \\ ${ }^{2}$ Laboratory of Evolutionary Genomics of Insects, the Federal Research Center Institute of Cytology and Genetics, Siberian \\ Branch of the Russian Academy of Sciences, Novosibirsk, Russia \\ *e-mail: sveta.alexx@mail.ru
}

Key words: mosquitos, Aedes, metaphase chromosomes, rDNA

Motivation and Aim: Mosquitos from the genus Aedes are vectors of many human and animal diseases such as yellow fever, Zika fever, dengue fever, chikungunya and other. The Aedes species mosquitoes are spread all over the world. Some of the species inhabit local native areas but other invade in large territories outside of their native range. Thus, precise identification of the Aedes species is of medical importance. Many species in the Aedes genus is difficult to identify. The complex methods are required for precise identification of some Aedes species. The analysis of metaphase chromosomes in the Aedes species can be an additional tool for species identification that can be used in combination of other methods.

Methods and Algorithms: A comparative analyses of the metaphase chromosomes of 4 Aedes species (Ae. excrucians, Ae. behningi, Ae. intudens, Ae. punctor) were performed. Lacto-aceto-orcein chromosome stain and imagJ program were used for measuring of the chromosome length. C- and DAPI stains visualized centromeric regions and some patterns in intercalary areas. Fluorescent in situ hybridization (FISH) was used to analyze the location of rDNA genes.

Results: Based on morphological data these 4 species belong to two different groups in Aedes genus. Ae. excrucians, Ae. behningi belong to Cantans group and Ae. intudens, Ae. punctor are part of Communis group. Analysis of rDNA localization indicate that rDNA is located in chromosome 1 in Cantans group mosquitoes but in contrast, in chromosome 2 in Communis group mosquitoes. The chromosome length are different for all analyzed species of Aedes genus (Ae. excrucians, A. behningi, Ae. intudens, and Ae. punctor). Calculation of centromeric index reveals that all three pairs of chromosomes are centromeric. Cand DAPI stains show different size and brightness of centromeric regions among the species.

Conclusion: The chromosome analysis of metaphase chromosomes of Aedes species can be used as a chromosome-based tool for identification of Ae. excrucians, Ae. behningi, Ae.intudens, Ae. punctor mosquito species in a combination with other identification methods.

Acknowledgements: Mosquitos collections and chromosome preparations was funded by RFBR, project number № 19-34-90044 to VNS. The data analysis and FISH was supported by the Russian Science Foundation Grant No. 19-14-00130 to Maria V Sharakhova. 


\title{
Comparative analysis of the efficiency of gene expression of bacterial D-lactate dehydrogenases in yeast Schizosaccharomyces pombe
}

\author{
Anisimova E.O. ${ }^{1,2 *}$, Blokhina K.S. ${ }^{2}$, Tarutina M.G. ${ }^{1,2}$, Sineoky S.P. ${ }^{2}$ \\ ${ }^{1}$ NRC «Kurchatov Institute»- GOSNIIGENETIKA, Kurchatov Genomic Center, NRC «Kurchatov Institute», Moscow, Russia \\ ${ }^{2} N R C$ «Kurchatov Institute», Moscow, Russia \\ *e-mail: ekaterina.genetika@gmail.com
}

Key words: Schizosaccharomyces pombe, D-lactic acid, gene expression

Motivation and Aim: Lactic acid (LA) is a platform chemical for the sustainable production of various materials. In recent years, there has been a growing interest in poly lactic acid (PLA) as a biodegradable polymer that is chemically synthesized from LA produced by microbiological process from renewable resources. There are two enantiomers of lactic acid: L-LA and D-LA. Both optical isomers are required to produce PLA with improved physical properties (thermochemical properties and higher rate of PLA biodegradation), which can be achieved by creating a stereo complex PLA with different combination ratios of the optically pure L-LA and D-LA isomers [1]. The production of optically pure D-LA has commercial attention because of the rapid growth of the PLA industry.

Methods and Algorithms: An acid-tolerant to high concentrations of lactic acid the S. pombe strain was used as recipient for a low-pH $D$-LA production. The $S$. pombe strain doesn't produce $D$-LA, so there were constructed the genetically modified $S$. pombe strains containing $D-L D H$ genes from Leuconostoc mesenteroides [2], Lactobacillus delbrueckii [3] и Lactobacillus plantarum [4] - bacterial producers of highly stereospecific $D$-LA. Recombinant strains were cultivated in tubes and the concentrations of $D$-LA were measured.

Results: The $S$. pombe strain expressing $D-L D H$ gene from $L$. plantarum produced more $D$-LA in comparison with strains expressing two other $D-L D H$ genes.

Conclusion: This investigation can be used to construct a highly effective strain that produces $D$-LA under acidic fermentation conditions.

Acknowledgements: Supported by the Ministry of Science and Higher Education of the Russian Federation (Grant No. 075-15-2019-1658), and was performed using the resources of the Bioresource Center - AllRussian Collection of Industrial Microorganisms.

\section{References}

1. Wang, Y., Tashiro, Y. and Sonomoto, K. Fermentative production of lactic acid from renewable materials: Recent achievements, prospects, and limits. Journal Bioscience and Bioengineering. 2015;119(1):10-18.

2. Seung-Ho Baek et al. Improvement of D-Lactic acid production in Saccharomyces cerevisiae under acidic conditions by evolutionary and rational metabolic engineering, Biotechnol Journal. 2017;12(10).

3. Caili Zhang et al. Non-sterilized fermentation of highoptically pure d-lactic acid by a genetically modified thermophilic Bacillus coagulans strain, Microbial Cell Factories. 2017;16(1):213.

4. Kenji Okano et al. Efficient production of optically pure D-lactic acid from raw corn starch using genetically modified L-lactate dehydrogenase gene-deficient and $\alpha$-amylase secreting, Applied Environmental Microbiol. 2009;75(2):462467. 


\title{
Event related potentials (ERP) of the brain in the conditions of the stop-signal paradigm in humans during the period of adaptation to the sub-polar climate
}

\author{
Astakhova T. ${ }^{*}$, Tamozhnikov S. ${ }^{2}$, Karpova A. ${ }^{3}$, Afanaseva E. ${ }^{3}$, Nikonov N. ${ }^{4}$, Chikacheva S. ${ }^{4}$, \\ Savostyanov A. ${ }^{1,2,5}$ \\ ${ }^{1}$ Novosibirsk State University, LBMSHB, Humanities Institute, Novosibirsk, Russia \\ ${ }^{2}$ State Scientific-Research Institute of Physiology and Basic Medicine, Novosibirsk, Russia \\ ${ }^{3}$ North-Eastern Federal University, Yakutsk, Russia \\ ${ }^{4}$ Yakutsk Medical College, Khandyga, Sakha Republic, Russia \\ ${ }^{5}$ Institute of Cytology and Genetics SB RAS, Novosibirsk, Russia \\ *e-mail: tastahova95@yandex.ru
}

Key words: climate adaptation, motor control, ERP, stop signal paradigm

Motivation and aim: Adaptation to extreme climate conditions is accompanied by a restructuring in the functional activity of the brain. One of the cognitive abilities that are critically important for the success of adaptation is the ability to regulate complex motor responses under time pressure conditions. The stop signal paradigm (SSP) is an experimental method that allows to objectively evaluate various aspects of individual ability to regulate conscious purposeful movements. The aim of this study was to investigate the dynamics of brain activity in labor migrants in sub-polar conditions, using the analysis of brain event related potentials in the stop-signal paradigm.

Methods and Algorithms: The study involved 50 healthy young residents of the Khandyga village (Arctic region of Yakutia) and 50 healthy migrants who came to Yakutia for a long time from the southern regions (Central Asia, Africa). Migrants were examined twice - immediately after moving to Yakutia and six months after moving. In the experiment with simultaneous EEG registration, the subjects performed SSP tasks - they had to either quickly press the button after the target signal appeared, or suppress the movement they had already started after the "stop" signal appeared on the screen. Event related potentials (ERP) were assessed for different SSP conditions at different time intervals and in different areas of the cortex, which allowed to assess the difference between the indigenous population and migrants, and to see the dynamics of changes in the state of the brain in migrants during six months of adaptation.

Results: Differences between migrants and the local population were identified for the amplitude of the P300 peak in the frontal and parietal-occipital regions of the cortex for all SSP conditions. During adaptation, the differences between migrants and resident populations in the ERP amplitude decreased, which correlated with a decrease in the level of anxiety.

Conclusions: The stop-signal paradigm in combination with the event related potentials method allowed to assess the dynamics of changes in the functional activity of the brain associated with adaptive rearrangements in the system of control over behavior in the sub-polar climate.

Acknowledgements: Supported by the RFFI grant No. 18-415-140021. Research by A.N. Savostyanov was carried out within the budget of project of the ICG SB RAS No. 0324-2019-0040-C-01. 


\title{
Influence of 5-HT ${ }_{1 \mathrm{~A}}$ receptors overexpression in the hippocampus on behavior and the brain serotonin system of BTBR mice - the model of autism
}

\author{
Belokopytova I. ${ }^{1,2}$, Kondaurova E. ${ }^{2}$, Kulikova E. ${ }^{2}$, Khotskin N. ${ }^{2}$, Naumenko V. ${ }^{2}$ \\ ${ }^{1}$ Novosibirsk State University, Russia \\ ${ }^{2}$ Institute of Cytology and Genetics SB RAS, Novosibirsk, Russia \\ *e-mail: belokopytovaii@mail.ru
}

Key words: 5-HT system, $5-\mathrm{HT}_{1 \mathrm{~A}}$ receptor, autism, BTBR

Motivation and Aim: Large amount of data were collected on the possible involvement of the brain serotonin system in the mechanisms of autism. One of the key element in this neurotransmitter system is the 5-HT $\mathrm{HA}_{1 \mathrm{~A}}$ receptor, which mediates large amount functions associated with various types of behavior.

BTBR mice are known to model traits consistent with pathological behaviors in human autism. We showed that in these mice the functional activity of the $5-\mathrm{HT}_{1 \mathrm{~A}}$ is decreased and expression of the gene $C c 2 d l a$ encoding Freud-1 silencer of 5-HT $\mathrm{HA}_{1 \mathrm{~A}}$ receptor gene (Htrla) in the hippocampus is increased.

Methods and Algorithms: An adeno-associated viral construct was injected into the hippocampus of BTBR mice, causing overexpression of the Htrla gene. The effectiveness of the viral construct effect on behavior, gene expression of the serotonin system and the level of the $5-\mathrm{HT}_{1 \mathrm{~A}}$ receptor protein in the hippocampus was assessed after treatment 6 weeks.

Results: The introduction of a viral construct into the hippocampus of BTBR mice reduced their anxiety, increased learning and, as expected, increased the expression of the Htrla gene and the level of the 5-HT $1 \mathrm{~A}$ receptor protein in the hippocampus. At the same time, if failed for cause any differences in stereotypical behavior and degree of social interaction.

Conclusion: Anxiety is one of the accompanying symptoms of autism. This problem is common among people with this disease, and the usage of anxiolytics helps the disease easier. Overexpression of the Htrla gene in the hippocampus reduced anxiety in BTBR mice. These data is agreement with the fact that introduction of the 5- $\mathrm{HT}_{1 \mathrm{~A}}$ receptor agonist 8-OH-DPAT [8-hydroxy-2 - (di-n-propylamino) - tetralin], leading to these receptors activation, reduces anxiety in animals.

Thus, the adeno-associated viral construct carrying the Htrla gene has an anxiolytic effect and improves learning of BTBR mice - the model of autism.

Acknowledgements: Supported by the grant of the President of the Russian Federation for Doctors of Sciences MD-1120.2019.4. 


\title{
3DPredictor: machine learning-based algorithm for prediction of 3D chromatin structure
}

\author{
Belokopytova P. ${ }^{1,2 *}$, Nuriddinov M. ${ }^{1}$, Mozheiko E ${ }^{1}$, Fishman D. ${ }^{2}$, Valiev E. ${ }^{1}$, Fishman V. ${ }^{1,2}$ \\ ${ }^{1}$ Institute of Cytology and Genetics SB RAS, Novosibirsk, Russia \\ ${ }^{2}$ Novosibirsk State University, Novosibirsk, Russia \\ *e-mail: belka2195@mail.ru
}

Key words: Hi-C, machine learning, modelling, promoter-enhancer interactions, chromosomal rearrangements

Motivation and Aim: The question about the exact role of spatial genome organization in regulation of gene expression is still under active debate. However, several studies $[1,2]$ shown that $3 \mathrm{D}$ chromatin folding plays an important role in gene regulation and alterations of spatial chromatin structures can lead to gene misexpression and diseases. It is known that different epigenetic marks and transcriptional factors correlate with various genomic features. In this way modelling helps to reveal main features and patterns underlying 3D genome architecture using epigenetic data as input. Moreover, such approach can be implemented for prediction of consequences of chromosomal rearrangements.

Methods and Algorithms: All data was processed with own scripts written on Python 3.6. Gradient boosting regressor from XGBoost was used as the main machine-learning algorithm

Results: We developed 3DPredictor algorithm which can efficiently predicts 3-dimensional chromatin structures using epigenetic chromatin features as input data. The algorithm could find complex patterns between epigenetic marks and 3D chromatin architecture using machine learning-based approach. Predicted heatmaps are cell-specific and 3DPredictor can be used for prediction of Hi-C maps for different mammal cell types. One of the applications of this method is prediction of chromatin and in particular enhancerpromoter rewiring after chromosomal rearrangements. We used one of well-studied examples of pathological changes caused by 3D chromatin perturbations and implemented our algorithm to predict consequences of such rearrangement. We found that 3DPredictor captures the majority of ectopic interactions. Therefore, this method can be used for prediction of 3D chromatin folding of normal and rearranged genomes.

Conclusion: All code is available at https://github.com/labdevgen/3Dpredictor. 3DPredictor online tool is available at https://genedev.bionet.nsc.ru/Web_3DPredictor/.

Acknowledgements: Supported by the RFBR grant \#18-29-13021. All computations were performed with support of the Computational Cluster of the NSU and Computational Nodes of the Institute of Cytology and Genetics (Budget Project \#0324-2019-0041).

\section{References}

1. Rodríguez-Carballo E. et al. The HoxD cluster is a dynamic and resilient TAD boundary controlling the segregation of antagonistic regulatory landscapes. Genes Dev. Cold Spring Harbor Laboratory Press, 2017. Vol. 31, № 22. P. $2264-2281$.

2. Franke M. et al. Formation of new chromatin domains determines pathogenicity of genomic duplications. Nature. 2016.

Vol. 538, № 7624. P. 265-269. 


\title{
Characterization of two novel $V R N-B 3$ alleles in common wheat
}

\author{
Berezhnaya A.A. ${ }^{1,2 *}$, Kiseleva A.A. ${ }^{2}$, Salina E.A. ${ }^{2}$ \\ ${ }^{1}$ Novosibirsk State University, Novosibirsk, Russia \\ ${ }^{2}$ Institute of Cytology and Genetics SB RAS, Novosibirsk, Russia \\ *e-mail: al.berezhnayal@gmail.com
}

Key words: common wheat, genotyping, new alleles, heading time, $V R N-B 3$

Motivation and Aim: VRN-B3 wheat gene is one of the key elements of the heading time pathway, the trait that moderates the adaptability and productivity of common wheat. Before we started our research, it has been known only four alleles for the $V R N-B 3$ gene, including the wild type $v r n-B 3$ variant $[1,2]$. All other known alleles have the insertions at the promotor region. Those insertions change the transcription level of the gene, which affects the heading time of the plants. Our study aimed to find the new VRN-B3 alleles and to investigate its structural and functional characteristics.

Methods and Algorithms: In this study, 94 common wheat accessions from Russia were tested for the allelic diversity of the $V R N-B 3$ gene. We have designed specific primers that covered the promoter region using PrimerQuest Tool. Those samples that had a different PCR fragment size than known alleles were sequenced. Sequences were aligned by BioEdit version 7.2 software. Annotation was performed using Unipro UGENE version 35, BlastN analysis and the Transposable Elements Platform (TREP) database. A total RNA of 20 wheat plants leaves with different $V R N-B 3$ alleles were extracted at the two different growth stages: GS15 (5 leaves unfolded), GS31 (1st node) [3]. To compare expression levels by qPCR, we used four primer sets: two for our gene, and two as an internal control (eEF1a1 and RLI).

Results: Two novel alleles of the $V R N-B 3$ gene were discovered. Only wheat variety Velut carrying a 1617bp insertion and ten accessions carrying a 160-bp insertion in the promoter region. These alleles were designated as Vrn-B3d and Vrn-B3e, respectively. The analysis of the sequences showed that the insertion in the Vrn-B3d allele is a retrotransposon and is homologous to the Hordeum vulgare L. LTR retrotransposon (RLX_Hvul_Dacia_RND-1). The qPCR experiment did not show a difference in the transcription levels between $\bar{v} r n-B 3 / \mathrm{Vrn}-\mathrm{B} 3 d$ plant groups. Our field data indicated the plants carrying the $V r n-B 3 e$ allele are associated with later heading time in comparison to the plants with the wild type allele (p-value $<0.05$ ).

Conclusion: The study identified two new Vrn-B3 alleles and presented the data about its structural and functional characteristics. It demonstrated the potential of Russian wheat varieties for an investigation.

Acknowledgements: The reported study was funded by RFBR (No. 20-016-00059).

\section{References}

1. Chen F. [и др.]. Molecular characterization of vernalization and response genes in bread wheat from the Yellow and Huai Valley of China. BMC Plant Biol. 2013. № 1 (13).

2. Iqbal M., Shahzad A., Ahmed I. Allelic variation at the Vrn-A1, Vrn-B1, Vrn-D1, Vrn-B3 and Ppd-D1a loci of Pakistani spring wheat cultivars. Electronic Journal Biotechnol. 2011. № 1 (14). C. 1-9.

3. Zadoks J. C. et al. A decimal code for the growth stages of cereals. Weed research. 1974;14(6):415-421. 


\section{LTR retrotransposons in green plants show multiple examples of convergent evolution}

Biryukov M.*, Ustyantsev K.

Institute of Cytology and Genetics SB RAS, Novosibirsk, Russia

*e-mail: birykov@bionet.nsc.ru

Key words: LTR retrotransposons, convergent evolution, ribonuclease H, Tat

Motivation and Aim: An illustrative example of modular evolution is independent acquisition of additional ribonuclease $\mathrm{H}(\mathrm{aRNH})$ domains by distant evolutionary lineages of long terminal repeat retrotransposons (LTR-RTs) from genomes of green plants (Tat), parasitic protists oomycetes (Chronos and Archon), and vertebrate retroviruses. In all the cases, structures of the elements converged to a single 'retroviral' variant when the aRNH domain is fixed right after the original one. Tat LTR-RTs of flowering plants exhibit the highest structural diversity with various positions of aRNH in relation to the other domains. However, previous studies of Tat LTR-RTs diversity were mostly limited to flowering plants. At the moment there are numerous genome assemblies of non-flowering plants available which opens a great perspective to study early evolution of Tat LTR-RTs, and understand its general tendencies.

Methods and Algorithms: We implemented a standalone pipeline written in Python which uses NCBI RPSBLAST and CDD to mine LTR-RTs sequences with aRNH from genome assemblies of 72 non-flowering green plant genomes, automatically annotates domain structure of the identified elements, clusters them and returns non-redundant set of best-scored representative sequences for phylogenetic analysis. The phylogeny was evaluated using IQ-TREE.

Results: We analysed 72 genomes of non-flowering green plants. No aRNH-containing elements were found in genomes of green algae and liverworts. LTR-RTs with aRNH from ferns, lycophytes, mosses, and hornworts formed two new clusters outside Tat. Elements with the 'retroviral' structure were found in ferns, lycophytes, and hornworts. A new structural variant with aRNH upstream gag was identified in mosses and lycophytes. LTR-RTs with aRNH and the 'retroviral' structure from ancient gymnosperms (Ginkgo biloba, Gnetum montanum, and cypress species) formed a new cluster within Tat basal to Tat LTR-RTs of flowering plants. Phylogenetic analysis of aRNH suggests independent origin of aRNH domains in LTRRTs from (1) ferns and lycophytes, (2) hornworts, and (3) pinaceae species (Tat III), while (4) the aRNH domains of all other LTR-RTs found in non-flowering plants cluster together with aRNH from Tat LTRRTs of flowering plants.

Conclusion: With the data obtained from non-flowering plants, the diversity of aRNH-containing LTR-RTs is now spreads beyond Tat. Our analysis suggests at least 4 independent cases of plant LTR-RTs adapting the 'retroviral' structure, indicating its significance for the elements' selection. Structural convergence appears to be the leading tendency in evolution of plant LTR-RTs.

Acknowledgements: Supported by the RFBR (20-34-90114) and Russian State Budget Project No. 02592019-0010-C-01. 
DOI 10.18699/SBB-2020-08

\section{Genetic analysis of some thyme cultivars grown at the Nikita Botanical gardens' collection plots}

Bulavin I.

FSFIS “The Labour Red Banner Order Nikita Botanical Gardens - National Scientific Center of the RAS”, Yalta, Russia e-mail: labgennbs@yandex.ru

Key words: thyme cultivars, RAPD-PCR, genetic similarity

Motivation and Aim: Breeding of essential oil plants includes demonstration of the distinctive morphological and biochemical characteristics compared to parental forms. In the Nikita Botanical Gardens gene pool collection of the thyme plants are represented by different species, cultivars, forms and chemotypes. The objective of our study was to evaluate the genetic similarity of the thyme cultivars obtained in the NBG.

Methods and Algorithms: Thymus mastichina cv. 'Svetliachok', Thymus striatus cv. 'Jubileiniy' and Thymus vulgaris cv. 'Fantazia' were used. DNAs were isolated from intact young leaves by CTAB-method with $2 \%$ polyvinylpyrolidone (PVP). RAPD-PCR was performed with BioMaster HS-Taq PCR kit (BiolabMix, Russian Federation) and OPA1-6 primers in the C1000 ${ }^{\mathrm{TM}}$ Thermal Cycler (Bio-Rad, Singapore) under the following condition: initial denaturation at $95^{\circ} \mathrm{C}$ for $5 \mathrm{~min}$ followed by 30 cycles of incubation at $94^{\circ} \mathrm{C}$ for $30 \mathrm{~s}$, annealing at $32^{\circ} \mathrm{C}$ for $30 \mathrm{~s}$ and incubation at $72^{\circ} \mathrm{C}$ for $30 \mathrm{~s}$ and with a final extension step at $72{ }^{\circ} \mathrm{C}$ for $5 \mathrm{~min}$. The amplified fragments were analyzed by electrophoresis in $1.5 \%$ agarose gel with $1 \times \mathrm{TBE}$ buffer at $100 \mathrm{~V}$ during $1 \mathrm{~h}$ using universal power supply PowerPacTM (Bio-Rad, Singapore) and imaged with E-box documentation system (Vilber Lourmat, France). DNA polymorphisms generated RAPD-PCR were calculated based on binary matrix in PAST software using Jaccard's similarity coefficient.

Results: Used 6 RAPD primers generated 81 amplicons, ranging basically from $200 \mathrm{bp}$ to $1,500 \mathrm{bp}$ in size. The number of bands in the selected primers varied from 3 (OPA 5) to 7 (OPA 1, 3,6). According to our data, T. mastichina cv. 'Svetliachok' formed separated cluster. Its genetic similarity with T. striatus cv. 'Jubileiniy' was 0.72 and with T. vulgaris cv. 'Fantazia' - 0.78. Similarity between T. striatus cv. 'Jubileiniy' and T. vulgaris cv. 'Fantazia' was 0.86 . Obtained results were natural, since investigated plants, especially T. mastichina, have distinctive morphology and belong to different sections (Mastichina, Thymus and Hyphodromi) according to the botanical classification.

Conclusion: Genetic analysis confirmed that cultivars obtained in the NBG belonged to one group, however were also differed. These differences clearly visible for T. mastichina, T. striatus cv. 'Jubileiniy' and T. vulgaris cv. 'Fantazia' have higher genetic similarity.

Acknowledgements: Supported by State Assignment No. 0829-2019-0038 of the FSFIS "NBG-NSC" and done on the base of the Unique Scientific Installation "Scientific Center of Plant Biotechnology, Genomics and Conservation" of the FSFIS "NBG-NSC". 


\title{
Changes in expression of genes associated with neurogenesis during development of Alzheimer's disease signs in OXYS rats
}

\author{
Burnyasheva A.O.*, Rudnitskaya E.A., Stefanova N.A., Kolosova N.G. \\ Institute of Cytology and Genetics SB RAS, Novosibirsk, Russia \\ *e-mail: burn.alena2505@mail.ru
}

Key words: neurogenesis, neurotrophin, Alzheimer's disease, OXYS rats

Motivation and Aim: Alzheimer's disease (AD) is the most common type of age-related dementia worldwide. However, the precise mechanisms of its pathogenesis are not fully understood. One of the processes that may contribute to neurodegeneration is alteration of neuronal plasticity. Neurogenesis is one of the major mechanisms of neuronal plasticity, and neurotrophic supply is crucial for it. Using OXYS rats as a suitable model of $\mathrm{AD}$ previously we have shown that development of $\mathrm{AD}$ signs is accompanied by changes in expression of genes involved in neurotrophic signaling pathway. Thus in this work we investigated a link between changes in expression of neurogenesis-associated genes and development of AD-like pathology in OXYS rats.

Methods and Algorithms: 20-days-, 3-5- and 18-months-old male OXYS and Wistar (control) rats were used. The RNA-seq data obtained for hippocampus were used to analyze differentially expressed genes involved in neurogenesis according to MANGO (Mammalian Adult Neurogenesis Gene Ontology) database. These genes were functionally annotated using DAVID (Database for Annotation, Visualization and Integrated Discovery). ELISA was used to quantify the levels of nerve growth factor (NGF) and brainderived neurotrophic factor (BDNF), TrkA and $\mathrm{p} 75^{\mathrm{NTR}}$ receptors, western-blot analysis was used to quantify levels of TrkB and phosphorylated TrkB (phTrkB) receptors in the hippocampus.

Results: We found that to the age of manifestation of AD signs in OXYS rats (from 20 days to 5 months) changes in expression of 22 genes were involved in the hippocampal neurogenesis. Functionally, these genes were associated with neuronal precursor cell proliferation, cellular response to glucose stimulus and positive regulation of angiogenesis. Changes in gene's expression might be due to activation of neurotrophic signaling observed in OXYS rats at the age of 3 months: levels of BDNF, pro-survival TrkA receptor of NGF and pro-apoptotic $\mathrm{p} 75^{\mathrm{NTR}}$ receptor were higher compared to Wistar rats. Progression of AD-like pathology in OXYS rats (from 5 to 18 months of age) is accompanied by changes in expression of 25 genes involved in neurogenesis. These genes were associated with angiogenesis, response to oxidative stress and negative regulation of cell death. The changes occurred against background of depletion of neurotrophic supply: the levels of BDNF and activation of its receptor (phTrkB/TrkB ratio) decreased in OXYS rats. However, the levels of NGF increased with age in both rat strains and may be considered as a compensatory response to slow down neuronal loss of function.

Conclusion: Alterations of neurotrophic supply in the hippocampus occur during development of AD-like pathology in OXYS rats and may result in disturbances of hippocampal neurogenesis.

Acknowledgements: This work was supported by grant from the Russian Science Foundation (project \# 1915-00044). 
DOI 10.18699/SBB-2020-10

\title{
Structural heterogeneity of the EIN3 binding site affects the characteristics of transcriptional response to ethylene in Arabidopsis
}

\author{
Dolgikh V.A. ${ }^{1 *}$, Levitsky V.G. ${ }^{1,2}$, Oschepkov D.Y. ${ }^{1}$, Zemlyanskaya E.V. ${ }^{1,2}$ \\ ${ }^{1}$ Institute of Cytology and Genetics SB RAS, Novosibirsk, Russia \\ 2. Novosibirsk State University \\ *e-mail:dolgikh@bionet.nsc.ru
}

Key words: bioinformatics, transcription factor, ETHYLENE-INSENSITIVE3, EIN3 binding site, ChIP-seq, RNA-seq

Motivation and Aim: ETHYLENE INSENSITIVE 3 (EIN3) transcription factor is the key transcriptional regulator of ethylene response. It activates target genes transcription upon binding a short sequence in their promoters called EBS (EIN3 binding site) [1]. EIN3 is able to bind DNA as a homodimer and as a heterodimer [2]. It is possible, the nucleotide context at the flanks can determine the protein binding mode forming EBS structural variants. In turn, a variety of structural variants can provide variability of ethylene transcriptional response. However, genome-wide studies of the EBS architecture have not been conducted. Here we performed a systematic bioinformatics analysis of the EIN3 binding site architecture and its role in the regulation of the EIN3-dependent transcriptional response to ethylene.

Methods and Algorithms: We analyzed publicly available ChIP-seq data on EIN3 binding and RNA-seq data on ethylene-induced transcriptomes for 1, 4 and 12 hours of ethylene treatment [3]. For motif analysis, we used Homer [4] and MCOT [5]. To associate EBS structural variants with EIN3 binding and response to ethylene we performed Fisher's exact test.

Results: We discovered three structural variants of EBS in EIN3 ChIP-seq peaks. (1) 2EBS(-1), a head-tohead EBS repeat with 1 bp overlap; (2) GC-EBS, monomeric EBS flanked with GC-rich tract upstream the core EBS; (3) TEIL-like EBS, monomeric structural variant similar to the binding site of EIN3 homolog in tobacco. We found genes containing each of them in promoter. Using EIN3 ChIP-seq binding data, we found that only $2 \mathrm{EBS}(-1)$ was stably bound with EIN3. Using ethylene-induced RNA-seq data we found that of all structural variants only 2EBS(-1) was strongly associated with the ethylene response.

Conclusion: The results obtained indicate that 2EBS(-1) is the main structural variant of EBS, providing the most pronounced response to ethylene. Whereas GC-EBS and TEIL-like EBS can mediate more specific ethylene-related reactions.

Acknowledgements: Supported by the RSF (20-14-00140) and State Budget Project (0324-2019-0040).

\section{References}

1. Kosugi S. and Ohashi Y. (2000) Cloning and DNA-binding properties of a tobacco Ethylene-Insensitive3 (EIN3) homolog. Nucleic Acids Res. 28(4):960-967.

2. Song J. et al. (2015) Biochemical and Structural Insights into the Mechanism of DNA Recognition by Arabidopsis ETHYLENE INSENSITIVE3. PLoS One. 10(9):e0137439.

3. Chang K.N. et al. (2013) Temporal transcriptional response to ethylene gas drives growth hormone cross-regulation in Arabidopsis. Elife. 2:e0675.

4. Heinz S. et al. (2010) Simple combinations of lineage-determining transcription factors prime cis-regulatory elements required for macrophage and b cell identities. Mol. Cell. 38(4):576-589.

5. Levitsky V. et al. (2019) A single ChIP-seq dataset is sufficient for comprehensive analysis of motifs co-occurrence with MCOT package. Nucleic Acids Res. 47(21):e139. 


\title{
Genome assembly of Fusarium oxysporum f. sp. lini using a combination of Oxford Nanopore and Illumina reads
}

\author{
Dvorianinova E.M. ${ }^{1,2 *}$, Novakovskiy R.O. ${ }^{1}$, Pushkova E.N. ${ }^{1}$, Kudryavtseva L.P. ${ }^{3}$, Rozhmina T.A. ${ }^{1,3}$, \\ Krasnov G.S. ${ }^{1}$, Melnikova N.V. ${ }^{1}$, Dmitriev A.A. ${ }^{1}$ \\ ${ }^{1}$ Engelhardt Institute of Molecular Biology, Russian Academy of Sciences, Moscow, Russia \\ ${ }^{2}$ Moscow Institute of Physics and Technology, Dolgoprudny, Russia \\ ${ }^{3}$ Federal Research Center for Bast Fiber Crops, Torzhok, Russia \\ *e-mail: dvorianinova.em@phystech.edu
}

Key words: flax pathogens, $F$. oxysporum f. sp. lini, genome assembly, Nanopore, Illumina

Motivation and Aim: Fusarium oxysporum f. sp. lini is regarded as one of the most harmful flax pathogens, causing its wilt. Since it is of high significance to study this species at molecular and genetic levels, its genome sequence will be of great help in such a field of investigations. Thus, our aim was to achieve a high-quality genome assembly of $F$. oxysporum $\mathrm{f}$. sp. lini pathogenic isolate \#39. We used a combination of Nanopore and Illumina sequencing platforms that allow one to obtain long and high accuracy reads respectively.

Methods and Algorithms: F. oxysporum pathogenic isolate \#39 was provided by the Institute for Flax (Torzhok, Russia) and grown on potato dextrose agar for 3 weeks. Pure high-molecular DNA was extracted from fungal mycelium according to our developed protocol. The assessment of quality and quantity of the extracted nucleic acid was performed by the methods of fluorometry (Qubit 2.0), spectrophotometry (Nanodrop), and electrophoresis in $0.8 \%$ agarose gel. DNA libraries were prepared and sequenced on Illumina (HiSeq 2500 instrument, HiSeq Rapid SBS Kit V2, 2×250 bp) and Nanopore (MinION instrument, FLO-MIN-106 R9.4 flow-cell) platforms according to the manufacturers' protocols. Nanopore reads were bacecalled using guppy 3.2.2, and low-quality ones were filtered out using trimmomatic 0.38 . The initial assembly was performed using Canu 1.8 and polished twice. Firstly, we used Racon 1.4.3 and Medaka 0.12.1 for polishing with Nanopore reads and then POLCA for assembly correction with filtered and trimmed Illumina reads.

Results: After sequencing, we managed to achieve 110x coverage in total - 80x for Nanopore reads and $30 \mathrm{x}$ for Illumina data. According to BUSCO, the completeness of the final assembly appeared to be $99.5 \%$, while QUAST statistics were the following: total length of $59 \mathrm{MB}, \mathrm{N} 50$ of $3.3 \mathrm{MB}, 35$ contigs.

Conclusion: The combination of data received from the two sequencing platforms allowed us to obtain a high-quality assembly of $F$. oxysporum $\mathrm{f}$. sp. lini genome, the knowledge of which will support further investigations of $F$. oxysporum and flax-pathogen interaction. The assembled genome can be accessed at DDBJ/ENA/GenBank (accession - WHMS00000000, BioProject accession - PRJNA578147).

Acknowledgements: Supported by RSF (16-16-00114, genome sequencing and assembly) and RFBR (1934-90055, the development of a protocol for DNA extraction). 


\title{
Molecular characterization of population level genetic diversity of several endemic species of Thymus L. (Lamiaceae) by using ISSR markers
}

\author{
Emirsaliiev A.O.*, Brailko V.A., Mitrofanova I.V. \\ Federal State-Funded Institution of Science "The Labor Red Banner Order Nikita Botanical Gardens - National Scientific \\ Center of the Russian Academy of Sciences", Yalta, the Russian Federation \\ *e-mail: asantaraqtasli@gmail.com
}

Key words: Thymus pseudohumillimus, endemic flora, PCR, polymorphism

Motivation and Aim: A Thymus L. is one of the largest Lamiaceae genera with great practical value. Studies of perspective thyme species introduction is problematic due to the extra endemism coupled with wide infra-generic hybridization possibilities and numerous spontaneous hybrids known, high morphological polymorphism and unclear taxonomic status of a most species $[1,2,3]$. The goals of this work were preliminary study of population level genetic polymorphism of a narrow endemic species of Crimean Flora, belonging to the Western Yailae group - Thymus pseudohumillimus Klokov et Des.-Shost., and a forecast on it's population sustainability.

Methods and Algorithms: DNA was extracted from fresh young leaves of Th. pseudohumillimus (six individuals), agg. Th. roegnerii K. Koch (two individuals) and putative hybrid of theirs (two individuals) according to the $\mathrm{CTAB}$ protocol with addition of $2 \%$ polyvinylpyrrolidone. Quality and quantity of DNA extracted were analyzed on NanoPhotometer NP80 (Implen, Germany). For PCR, BioMaster HS-Taq PCR $(2 \times)$ commercial kit (Biolabmix, Russian Federation) was used. DNA was amplified with 35 cycles using $\mathrm{C} 1000^{\mathrm{TM}}$ Thermal Cycler (Bio-Rad, Singapore) in regime: initial denaturation at $94{ }^{\circ} \mathrm{C}$ for $2 \mathrm{~min}$, cyclic denaturation at $94^{\circ} \mathrm{C}$ for $30 \mathrm{sec}$, proceeding to the primer-specific annealing and elongation at $72^{\circ} \mathrm{C}$ for a 1 min each, and final elongation at $72^{\circ} \mathrm{C}$ for $7 \mathrm{~min}$. For UBC-824 and UBC-826 annealing temperature was $55^{\circ} \mathrm{C}$, and for UBC-864 and UBC- $880-52^{\circ} \mathrm{C}$.

Results: The amount of DNA, obtained from $100 \mathrm{mg}$ of fresh leaves, has been $28 \mu \mathrm{g}$ with ranging between 7 and $52 \mu \mathrm{g}$. Purity has been scored with $\mathrm{A}_{260 / 230}$ and $\mathrm{A}_{280 / 260}$ spectres, locating accordingly at 2.072 and $2.236 \mathrm{~nm}$.

The UBC-824 primer was more polymorphic. The bands number varied from 7 to 11 with size 200-2,000 bp. Gels after electrophoresis were analyzed and on binary matrix base, UPGMA and Neighbor Joining dendrograms performed [4]. Putative hybrid individuals ended with agg. Th. roegnerii into a single clade.

Conclusion: ISSR PCR analysis has showed that the Th. pseudohumillimus is highly polymorphic and has molecular similarities to the $T$. roegnerii.

Acknowledgements: Investigation was performed in the framework of the State Assignment № 0829-20190038 of the FSFIS "NBG-NSC" and done on the base of the Unique Scientific Installation "Scientific Center of Plant Biotechnology, Genomics and Conservation" of the FSFIS "NBG-NSC".

\section{References}

1. Tohidi B., Rahimmalek M., Trindade H. Review on essential oil, extracts composition, molecular and phytochemical properties of Thymus species in Iran. Industrial Crops Products. 2019;134(August):89-99. doi:10.1016/j.indcrop.2019.02.038.

2. Yousefi V., Najaphy A., Zebarjadi A., Safari H. Molecular characterization of thymus species using ISSR markers. Journal Animal Plant Sci. 2015;25(4):1087-1094.

3. Васюков B.M. О крымских тимьянах (Thymus L., Lamiaceae). Новости систематики высших растений. 2014;45:110-121.

4. Pavel, A.B., Vasile, C.I. PyElph - a software tool for gel images analysis and phylogenetics. BMC Bioinformatics. 2012;13(9). https://doi.org/10.1186/1471-2105-13-9. 


\title{
Expression profile of CENH3 paralogs in different tissues of the rye-wheat amphiploids and their parents
}

\author{
Gatzkaya S.S.*, Evtushenko E.V. \\ Institute of Molecular and Cellular Biology SB RAS, Novosibirsk, Russia \\ *e-mail: jait@mail.ru
}

Key words: Centromeric histone CENH3, gene expression, rye, secalotriticum, remote hybridization

Motivation and Aim: It was established that centromeric histone H3 (CENH3 in plants) plays a major role in the formation and proper functioning of centromeres. The created allopolyploid hybrids secalotritikum (rye $\mathrm{x}$ wheat) are a new interesting model for studying the effect of remote hybridization on the genome regions that are responsible for the correct division and distribution of chromosomes in hybrid cells. The aim of this work was to compare the expression levels of two forms of centromeric histone H3 ( $\alpha \mathrm{CENH} 3$ and $\beta C E N H 3$ ) in stable rye-wheat hybrids secalotriticum and their parental species.

Methods and Algorithms: cDNA samples were isolated from vegetative and generative tissues of two varieties of secalotriticum (Secalotriticum Verasen $\times$ Mikhas and Secalotriticum Verasen $\times$ Dubrava) and parental species (tetraploid rye $S$. cereale v. Verasen and hexaploid hybrids Triticale v. Mikhas and Triticale v. Dubrava). Relative expression levels were determined by RT-PCR with SYBR Green I. Reference gene Ta2776 was used to normalize expression levels of the CENH3 genes. Calculations were performed using the LC480 software (Roche) by 'Relative Quantification analysis with high confidence 2nd Derivative max'.

Results: The main forms of the centromeric histone $\mathrm{H} 3$ gene, $\alpha C E N H 3$ and $\beta C E N H 3$, are expressed at all stages of individual plant development in both hybrids and in their parents. The transcriptional activity profiles of $\alpha C E N H 3$ and $\beta C E N H 3$ are almost identical in secalotriticum hybrids and the parental species. In all the studied tissues the expression level of $\alpha C E N H 3$ usually an order of magnitude higher than the expression level of $\beta C E N H 3$. There is a significant decrease in the expression levels of both $C E N H 3$ forms in vegetative tissues after germination, namely in the leaf tissue expression levels 8 times lower, on average, compared to the tissues of radicle and coleoptile. Expression levels in the generative tissue increase many times compared to vegetative tissue, and the expression of both forms is 2-3 times higher in the pistil tissue than in the anther tissue.

Conclusion: The activity of the CENH3 genes remains at the same level in genomes of the stable secalotriticum hybrids compared to genomes of the parental species, that is, the hybrid cytoplasm does not affect this feature. These results reflect the ability of centromeres to adapt to a new genetic environment. Acknowledgements: Supported by the Russian Foundation for Basic Research (grant 20-04-00699 A). 


\title{
Nanopore-based retrotranscriptome analysis and proteome screening of $A$. thaliana $\mathbf{d d m} 1$ mutant
}

\author{
Gvaramiya S. ${ }^{1 *}$, Merkulov P. ${ }^{1}$, Omarov M. ${ }^{1,2}$, Kirov I. ${ }^{1}$ \\ ${ }^{1}$ All-Russia Research Institute of Agricultural Biotechnology, Moscow, Russia \\ ${ }^{2}$ National Research University Higher School of Economics, Moscow, Russia \\ *e-mail: sofia.gvaramia@gmail.com
}

Key words: retrotransposons, transposable elements, retrotranscriptome, retroproteome

Motivation and Aim: The prevalent class of mobile genetic elements in plants is LTR retrotransposons (RTEs), which transpose via RNA intermediate. The most of RTEs are silenced by DNA methylation and siRNA system [1]. Though, novel studies indicate that some RTEs can escape the repression of their activity and even move through genome [2] but the mechanisms which help RTEs to avoid inhibition are poorly understood. Moreover, studying of RTE expression is challenging because of bioinformatic tool limitations and low RTE expression.

Methods and Algorithms: In this research, we performed direct RNA sequencing of ddml arabidopsis mutants on MinION (Oxford Nanopore Technologies, kit SQK-002). We used three assemblers with different settings - pinfish [3], StringTie2 [4] and FLAIR [5] for TE transcript assembly. Prediction of active TEs was carried out with the proper pipeline. All selected elements were verified by RT-PCR. For mass spectrometry analysis proteins were isolated by phenol extraction method [6] and PSM identification was carried out by "Peaks" software (Bioinformatics Solutions Inc.).

Results: More than 700 thousand reads were obtained from single MinION R9.4.1 cell. Using this data, we revealed a number of transposons that transcriptionally active in mutant and wild type plants and identified four isoforms for transposon $E V D$. The mobility of this expressed TE was confirmed with eccDNA analysis. Using mass spectrometry analysis, we identified several TE proteins including transposase of DNA transposon in $d d m 1$ mutant total proteome.

Conclusion: The results obtained will be applied for further investigation of transposons evolution, activity and life cycle.

Acknowledgements: The work was carried out with the financial support of The Russian Foundation for Basic Research (RFBR grant No. 20-34-70032).

\section{References}

1. Slotkin, R. K. \& Martienssen, R. A. Transposable elements and the epigenetic regulation of the genome. Nature Rev. Genet. 8, 272-285 (2007).

2. Thieme, M., Lanciano, S., Balzergue, S., Daccord, N., Mirouze, M., and Bucher, E. (2017) Inhibition of RNA polymerase II allows controlled mobilisation of retrotransposons for plant breeding. Genome Biol. 18, 134.

3. Oxford Nanopore Technologies. Pinfish. 2018. https://github.com/nanoporetech/pinfish.

4. Kovaka, S., Zimin, A.V., Pertea, G.M. et al. Transcriptome assembly from long-read RNA-seq alignments with StringTie2. Genome Biol 20, 278 (2019).

5. Tang, A.D., Soulette, C.M., van Baren, M.J. et al. Full-length transcript characterization of SF3B1 mutation in chronic lymphocytic leukemia reveals downregulation of retained introns. Nat Commun 11, 1438 (2020).

6. Faurobert M., Pelpoir E., Chaïb J. (2007) Phenol Extraction of Proteins for Proteomic Studies of Recalcitrant Plant Tissues. In: Thiellement H., Zivy M., Damerval C., Méchin V. (eds) Plant Proteomics. Methods in Molecular Biology, vol 355. Humana Press. 


\section{Genetic variability among 28 genomes of SARS-CoV-2 collected in Moscow in the early spring 2020}

Kaptelova V.V.*, Samoilov A.E., Valdokhina A.V., Bulanenko V.P., Korneenko E.V., Shipulina O.Y., Akimkin V.G., Speranskaya A.S.

Central Research Institute of Epidemiology of the Federal Service on Customers' Rights Protection and Human Well-being

Surveillance, Moscow, Russia

*e-mail: valeriia.kaptelova@gmail.com

Key words: SARS-CoV-2, pandemic, mutations, phylogeny

Motivation and Aim: Whole-genome analysis of SARS-CoV-2 is required for understanding the transmission of disease. In Russia, the first COVID-19 case was identified in early March. Early stages of SARS-CoV-2 outbreak in Russia were described in the recent paper by Komissarov et al. [1], but the number of analyzed genomes of SARS-CoV-2 originated from Moscow was limited. We aim to analyze genetic diversity among SARS-CoV-2 isolates collected in Moscow by the end of March - early April.

Methods and Algorithms: Previously designed primers panel [2] was used for SARS-CoV-2 full genome amplification. The PCR products of ranging from 1757 to $2054 \mathrm{bp}$ were mixed, purified, and sheared using Covaris M220. Libraries were constructed using the method of adapters ligation as described in [2]. Sequencing was performed on Illumina HiSeq 1500 (PE 250+250) or Illumina MiSeq (PE 250+250). Reads were trimmed by the quality and PCR primers, mapped to reference genome MT121215.1 using bowtie2. Reads with low mapping quality were filtered out using SAMtools. Basecalling was performed with GATK. Gvcf files were filtered with BCFtools. The consensus sequence was obtained with BEDTools and submitted to GISAID database (virus names starting with hCoV-19/Russia/CRIE). To create phylogenetic trees, we used 28 submitted sequences and the whole genomes from GISAID (20 august 2020), which were nearest to the each of the sequences (top 30). Duplicated sequences were removed from dataset and resulted 251 sequences were aligned using MAFFT v. 7.471. The phylogenetic tree was built using the Maximum Likelihood (ML) method implemented in MEGAX.

Results: Phylogenetic analysis of 28 SARS-CoV-2 isolates in Moscow showed that they are closely related to the European and American clades rather than Asian. All 28 isolates belong to different clades of B1 lineages (B1.1 and B1). We observed 3 to 6 mutations in each sequence compared to hCoV19/Wuhan/WIV04/2019 reference. Also, we found frameshift in one genome, in the position 27330 (ORF6 gene), GISAID accession EPI_ISL_462149. P323L and D614G mutations were found in all of the analyzed genomes. Furthermore, we found several rare mutations such as T16A (occurred 2 times in all sequences from GISAID), V359I (2 times), E39D (2 times), G13E (3 times, T176A ( 3 times), I112V (3 times).

Conclusion: All analyzed sequences fell into B1.1 and B1 clades. Our results are in agreement with [1], where most samples correspond to the B.1, B.1.1 lineages.

Acknowledgements: The study was funded by RFBR, project number 20-04-60561.

References

1. Andrey B Komissarov, Ksenia R Safina et al. Genomic epidemiology of the early stages of SARS-CoV-2 outbreak in Russia. medRxiv 2020.07.14.20150979; doi: https://doi.org/10.1101/2020.07.14.20150979.

2. AS Speranskaya, VV Kaptelova et al. SCV-2000bp: a primer panel for SARS-CoV-2 full-genome sequencing. bioRxiv 2020.08.04.234880; doi: https://doi.org/10.1101/2020.08.04.234880 


\title{
Novel candidate genes for grain texture in Russian wheat varieties
}

\author{
Kiseleva A.A. ${ }^{1 *}$, Leonova I.N. ${ }^{2}$, Pshenichnikova T.A. ${ }^{2}$, Salina E.A. ${ }^{1}$ \\ ${ }^{1}$ Kurchatov Genomics Center, Institute of Cytology and Genetics SB RAS, Novosibirsk, Russia \\ ${ }^{2}$ Institute of Cytology and Genetics SB RAS, Novosibirsk, Russia \\ *e-mail: antkiseleva@bionet.nsc.ru
}

Key words: Triticum aestivum, grain texture, grain hardness, puroindolines, GWAS

Motivation and Aim: Grain texture is an important milling characteristic of common wheat. Previously, it was shown that the Ha locus on 5DS, containing the puroindoline a, puroindoline $b$ and GSP-1 genes, has a crucial role in endosperm texture. Puroindoline-like genes mapped to chromosome group 7 also contribute to this trait. However, some other loci were detected on different chromosomes, but no specific genes were proposed to be involved in grain hardness organization.

Methods and Algorithms: There were 92 varieties adapted to the environments of the Siberia region used in this study. We estimated two parameters for grain texture in two years: flour particle diameter (FPD, $\mu \mathrm{m})$ and flour particle specific surface (FPSS, $\mathrm{cm} 2 / \mathrm{g}$ ). SNP genotyping was performed using the Illumina Infinium $15 \mathrm{k}$ Wheat platform by TraitGenetics $\mathrm{GmbH}$. The population structure was analysed using the R-based STRUCTURE-like inference algorithm LEA. For association analysis, a mixed model approach implemented in the R package "GENESIS" was used. The resulting mixed linear model considered fixed effects of SNPs and population structure and random effects for kinship. To estimate the expression of genes in the detected loci, we used data of the common wheat cultivar Azhurnaya developmental time course.

Results: Individual variance component analysis demonstrated that the genotypic variance principally contributed to flour particle size (79\%) and flour particle-specific surface (80\%). The assumption of ancestral populations $(\mathrm{K})$ with cross-entropy demonstrated that the most likely number of subpopulations was $\mathrm{k}=4$. The genotyping with gene-specific primers demonstrated that twenty-three varieties had allele Pina-DIk, which lacked both Pina and Pinb genes (double null allele). Association analysis revealed a total of 26 SNPs and Pina gene-specific marker to be significantly associated with grain texture. The most promising were SNPs on chromosomes $5 \mathrm{~B}$ and 7B. These MTAs demonstrated the highest significance after FDR correction. We selected four genes located on 5B (TraesCS5B02G010300, TraesCS5B02G010400, TraesCS5B02G010800, and TraesCS5B02G011700) highly expressed in grain at the hard dough and ripening stages and in the embryo proper.

Conclusion: In this study, we confirmed the crucial role of puroindoline genes in grain texture determination of Russian spring wheat varieties. We have demonstrated that rare allele Pina-Dlk is widely distributed in the studied panel of accessions. Likewise, we found a number of novel loci to be highly associated with grain texture and dissected genes from these loci. These genes are involved in the metabolism of galactolipids (DGDG) and carbohydrates (1,3- $\beta$-glucan).

Acknowledgements: The study was supported by Kurchatov Genomics Center of ICG (075-15-2019-1662). 
DOI 10.18699/SBB-2020-17

\section{De novo identification and sequence assembly of high-copy tandem repeats in raw data Oxford Nanopore plant DNA sequencing data}

Kolganova E. ${ }^{1}$, Muravenko O. ${ }^{2}$, Kirov I. ${ }^{1}$

${ }^{1}$ All-Russia Research Institute of Agricultural Biotechnology, Moscow, Russia

${ }^{2}$ Engelhardt Institute of Molecular Biology, Russian Academy of Sciences, Moscow, Russia

*e-mail: liza.colg@gmail.com

Key words: long-reads, ONP, tandem repeats, consensus

Motivation and Aim: High-copy tandemly organized repetitive sequences (TRs) may constitute a large part (up to $30 \%$ ) of plant genomes. They play important role in genome structure organization, cell division, and diversity. Yet, TR functions, origin, evolution, and genome organization are still poorly understood. Assembly of full-size clusters of tandem repeats from short reads can result in reduction in cluster of TRs and large-scale misassembles of sequences and remains a great challenge. Oxford Nanopore Technologies (ONT) directly sequences single molecules of DNA and is capable to generate long reads covering a significant part of individual TR genomic clusters. The exponentially growing of publicly available ONT datasets for plants having no reference genome assembly triggers us to design a pipeline for high-copy TRs identification in raw ONT reads. The relatively high error rate in data of nanopore sequencing compared to short sequencing makes it impossible to directly search for TRs by known tools (e.g. Tandem Repeat Finder) [1]. Therefore, in this work we have developed a pipeline for de novo identification and sequence assembly of high-copy tandem repeats in raw data ONT plant DNA data, to calculate TRs copy number variation and assembly consensus sequences for further analyses (e.g. FISH).

Methods and Algorithms: Pipeline works with Oxford Nanopore Technologies (ONT) sequencing data in FASTA or FASTQ formats. The success of this pipeline work was proven by the analysis of originally obtained Deschampsia antarctica ONT data. We identified more than 40 TRs. Of them, 27 high-copy TRs have been previously identified by several previous studies [2]. The data was used to evaluate the robustness of the pipeline in terms of TR sequence and TR genome abundancy. The results showed a high $(r=0.98$, P-value $<1$ e-15) correlation of TRs copy number estimated by our pipeline and by previous studies. Moreover, 13 new high-copy TRs have been found.

Conclusion: Our pipeline identifies high-copy TRs in raw long-reads. Furthermore, this pipeline will provide insights about novel TRs and increase knowledge about their structural organization and evolution. Source code and instructions for local installation are available at https:/github.com/Kirovez/nanoTRF. Acknowledgements: This work was financially supported by the RFBR (17-00-00336).

\section{References}

1. Benson G. Tandem repeats finder: a program to analyze DNA sequences. Nucleic Acids Research. 1999. Vol. 27 . Issue 2. P. 573-580.

2. González M.L., Chiapella J.O., Urdampilleta J.D. Characterization of some satellite DNA families in Deschampsia antarctica (Poaceae). Polar Biol. 2018. Vol. 41. Issue 3. P. 457-468. 


\section{Structural organization of TFL1-like genes of cowpea (Vigna unguiculata (L.) Walp.)}

Krylova E.*, Strygina K., Khlestkina E.

Federal Research Center N.I. Vavilov All-Russian Institute of Plant Genetic Resources, Saint-Petersburg, Russia

*e-mail: e.krylova@vir.nw.ru

Key words: determinate growth habit, TFL1, ATC, BFT, cowpea, Vigna unguiculata

Motivation and Aim. Cowpea (Vigna unguiculata (L.) Walp.) is a multipurpose globally important legume crop, the interest to which has greatly increased in recent years among breeders. Stem growth habit is one of the key features in determining plant architectonics. It is an economically important trait that interconnects with stem length, flowering duration, yield, resistance to lodging, and suitability of mechanical cultivation. Mutations in Terminal Flowerl (TFL1) gene and its homologs have been demonstrated to result in indeterminacy across genera. The group of TFL1-like genes includes TFL1, ATC, and BFT. Genome of $V$. unguiculata has been sequenced, but the molecular genetic mechanisms of stem growth habit control and the role of TFL1-like genes in them are not well understood. The aim of the present study was the identification and characterization of the structural and functional organization of TFL1-like genes in cowpea genome.

Methods and Algorithms: The search of homologues sequences of TFL1 in the genome of cowpea was conducted using BLASTN algorithm in LIS - Legume Information System (https://legumeinfo.org). The multiple alignment of nucleotide and amino acid sequences was made using MULTALIN v5.4.1 The cluster analysis using the MEGAX software was based on NJ algorithm. The promoter prediction was carried out with New PLACE. The annotation of the functional domains was made using InterPro. Modelling of 3Dstructures of the predicted amino acid sequences was made carried out using SWISSMODEL.

Results. The search of homologous sequences of the TFL1 gene of Arabidopsis thaliana was carried out in the genome of cowpea. In total, 4 sequences of TFL1-like genes were identified. All identified sequences were divided into three clades. The first clade included sequences highly homologous to the TFL1 gene of A. thaliana. The other two clades included genes homologous to genes ATC and BFT of A. thaliana. All identified protein sequences had all critical amino acid residues. Based on the results of the sequence analysis of identified TFL1-like genes, including the cis-regulatory regions, it can be assumed that these genes are maintained in a functional state.

Conclusion. Identification and analysis of genes responsible for the stem growth habit are required for the successful selection of modern varieties. In the genome of cowpea, we identified duplication of TFLI gene. The obtained results confirm the high evolutionary conservatism of genes involved in the molecular genetic control of the flowering initiation. Thus, this work expands the existing understanding of the molecular genetic mechanisms underlying the maintenance of indeterminacy in the growth of the shoot apical meristem, as well as in the control of the transition to flowering.

Acknowledgements: The present review was carried out within VIR project No. 0481-2019-0001. 


\title{
Cardiac mechanics, calcium overload and arrhythmogenesis
}

\author{
Kursanov A. ${ }^{1 *}$, Solovyova O. ${ }^{1,2}$, Katsnelson L. ${ }^{1}$, Medvedev K. ${ }^{2}$, Vasilyeva A. ${ }^{1,2}$, Vikulova N. ${ }^{1}$, \\ Markhasin V.S. ${ }^{1,2}$ \\ ${ }^{1}$ Institute of Immunology and Physiology UB of RAS, Yekaterinburg, Russia \\ ${ }^{2}$ Ural Federal University, Yekaterinburg, Russia \\ *e-mail: alexander.kursanov@gmail.com
}

Key words: calcium overload, rhythm disturbances, cardiac mechanics

Motivation and Aim: It is well-known that $\mathrm{Ca}^{2+}$ overload may cause cardiac arrhythmia. However, possible contribution of the mechanical factors to the arrhythmia development in $\mathrm{Ca}^{2+}$-overloaded cardiomyocytes has been insufficiently addressed. Earlier we have developed a mathematical model of cardiomyocyte electro-mechanical function [1] that predicted a significant role of the intra- and extracellular mechanical factors in arrhythmogenesys. Model prediction was verified in experiments on papillary muscles from the right ventricle of guinea pigs overloaded with calcium [2].

Methods and Algorithms: We utilized the cellular model to study effects of the electromechanical coupling between cardiomyocytes in a 1D heterogeneous muscle strand formed of $90 \%$ of normal (N) cardiomyocytes and $10 \%$ of sub-critical (SC) cardiomyocytes with decreased $\mathrm{Na}^{+}-\mathrm{K}^{+}$pump activity. Single $\mathrm{SC}$-cardiomyocytes did not demonstrate spontaneous activity during isometric contractions at a reference length. Regular fiber twitches at the reference initial cell length were induced by 1 bps electrical stimulation applied at an edge of the strand. Excitation spread along the tissue via electro-diffusional cell coupling followed by cell contractions and force development.

Results: Mechanical interactions between N- and SC-cells in the tissue resulted in the spontaneous activity emerged in the SC-zone between the regular stimuli. If the excitation wave spread from SC- to N-region, the SC-cells developed delayed after-depolarizations (DAD) that caused a slowly developing beat-to-beat decrease in the force of fiber contraction. If the excitation spread in opposite direction, DAD in the SCcells induced reflected downward excitation waves capturing the normal region and followed by extrasystoles in the whole fiber.

Conclusion: The results obtained in the model suggest that ectopic activity may emerge in a sub-critical myocardial region, e.g. comprising cardiomyocytes with moderately depressed $\mathrm{N}+\mathrm{K}+$ pump, due to its mechanical interactions in the myocardial tissue. Moreover, such ectopic zone may expand by capturing normal regions in myocardium via the electro-mechanical coupling between cardiomyocytes.

Acknowledgements: Supported by the RFBR (14-01-00885, 14-01-31134), by Presidium of UB RAS (12M-14-2009, 12-П-4-1067) and by UrFU (Act 211 of RF Government \# 02.A03.21.0006).

\section{References}

1. Katsnelson L.B. et al. Contribution of mechanical factors to arrhythmogenesis in calcium overloaded cardiomyocytes: Model predictions and experiments. Progress Biophysics Mol Biol. 2011;107(1):81-89.

2. Lashin S.A., Matushkin Yu.G. Haploid evolutionary constructor: new features and further challenges. In Silico. Biol. 2012;11(3):125-135. 
DOI 10.18699/SBB-2020-20

\title{
Influence of poly(ADP-ribose)polymerases 1 and 2 on base excisional repair in the context of nucleosomes
}

\author{
Kutuzov M.M. ${ }^{1,2 *}$, Belousova E.A. ${ }^{1}$, Lavrik O.I. ${ }^{1,2}$ \\ ${ }^{1}$ Institute of Chemical Biology and Fundamental Medicine, Siberian Branch of the Russian Academy of Sciences, ICBFM SB \\ RAS, Novosibirsk, Russia \\ ${ }^{2}$ Novosibirsk State University, Novosibirsk, Russia \\ *e-mail: kutuzov.mm@mail.ru
}

Key words: BER, PARP1, PARP2, nucleosome

DNA damages occur in the cellular genome as a result of exposure to genotoxic agents of both endogenous and exogenous origin. A specific repair system is responsible for correcting each type of damage in the cell. In DNA of eukaryotes damages which do not cause significant distortions in the structure of the DNA double helix are dominated. This type of damage is repaired by functioning of the base excision repair system (BER). The main stages of this system are well characterized, therefore, modern research is mainly devoted to the study of the regulation of this process.

DNA compaction level imposes additional restrictions on the efficiency of the repair processes. Successful repair of DNA damage during BER requires regulation not only of the stages of the repair system itself, but also regulation of the degree of DNA compaction.

Key regulatory BER proteins include poly(ADP-ribose)polymerase1 (PARP1) and poly(ADPribose)polymerase2 (PARP2). These proteins are also involved in the regulation of chromatin remodeling. In our work, we studied the effect of PARP1 and PARP2 proteins on the activity of key enzymes of the BER system, such as APE1 and DNA polymerase $\beta$, using both naked DNA and reconstructed model nucleosomes. During our work, we found that PARP1 and PARP2 have an inhibitory effect on the activities of APE1 and DNA polymerase $\beta$. At the same time, the effect of PARP1 is more pronounced. The inhibitory effect is weakened under (ADP-ribosyl)ation conditions.

The obtained results are in accordance with the current model of regulation of the interaction of PARP1 and PARP2 with DNA. In particular, under (ADP-ribosyl)ation conditions, autopoly(ADP-ribosyl)ation of PARP proteins occurs. This covalent modification leads to dissociation of the PARP-DNA or PARPnucleosome complex due to electrostatic repulsion of the ADP-ribose polymer and DNA.

Acknowledgements: This work was supported by the RFBR project No. 20-34-70028. 


\title{
A novel highly effective of $\beta$-mannanase producer on base Ogataea haglerorum yeast
}

\author{
Lazareva M.N. ${ }^{1}{ }^{2 *}$, Lapteva A.R. ${ }^{2}$, Tarutina M.G. ${ }^{1,2}$, Sineoky S.P. ${ }^{2}$ \\ ${ }^{1}$ NRC «Kurchatov Institute»- GOSNIIGENETIKA, Kurchatov Genomic Center, NRC «Kurchatov Institute», Moscow, Russia \\ ${ }^{2} N R C$ «Kurchatov Institute», Moscow, Russia \\ *e-mail: mari-mari.lm@yandex.ru
}

Key words: Ogataea haglerorum, producer, recombinant $\beta$-mannanase

Motivation and Aim: $\beta$-mannanases are enzymes of industrial applications and use in feed, food, pulp and paper industries, pharmacology and the production of detergents. $\beta$-mannanase (E.C.3.2.1.78) catalyzes the cleavage of internal $\beta$-1,4-glycoside bonds in the main polymer chain of the mannan molecule [1]. Requirements for enzyme properties vary depending on the field of application, but the most important criterion is the high specific activity of the enzyme, which is characteristic of some $\beta$-mannanases from Bacillus [2]. $\beta$-mannanase enzyme preparations are supplied to the Russian market by foreign companies. The development of highly effective domestic strains producing $\beta$-mannanase is an important goal to solve the problem of import substitution.

Methods and Algorithms: For the first time, thermotolerant methylotrophic yeast Ogataea haglerorum was used to construct the producer. To transform $O$. haglerorum yeast, an expression cassette was constructed containing, under the control of the $M O X$ promoter, a synthetic MANS gene encoding an enzyme identical to $97.4 \% \beta$-mannanases from $B$. subtilis MAFIC-S11 and B. subtilis WL-7 by BLAST.

Results: Using genetic engineering and selection methods, a stable highly productive strain of O. haglerorum, a $\beta$-mannanase producer, was obtained. Strain is characterized by high ability to express and secrete recombinant $\beta$-mannanase at temperature $37{ }^{\circ} \mathrm{C}$ under induction conditions. Strain produces about $1.0 \mathrm{mg} / \mathrm{ml}$ of enzyme when cultured in tubes; activity of $\beta$-mannanase is 14400 units $/ \mathrm{ml}$. The results of the work were included in the application for the patent of the Russian Federation: RU 2020120291 from 18.06.2020.

Conclusion: The resulting strain in its biotechnological parameters is comparable to the best foreign yeast strains - producers of $\beta$-mannanase. The properties of the ManS allow it to be used as an effective additive in animal feed industry.

Acknowledgements: Supported by the Ministry of Science and Higher Education of the Russian Federation (Grant No. 075-15-2019-1658), and was performed using the resources of the Bioresource Center - AllRussian Collection of Industrial Microorganisms.

\section{References}

1. Moreira L.R.S., Filho E.X.F. An overview of mannan structure and mannan - degrading enzyme systems. Appl Microbiol Biotechnol. 2008;79:165-178.

2. Chauhan P.S. et al. An overview of purification strategies for microbial mannanases. Int J Pharm Bio Sci. 2014;5(1):176192. 


\title{
Dissecting the bases of Bacillus thuringiensis host specificity: genomic and proteomic approaches
}

\author{
Malovichko Y. ${ }^{1,2 *}$, Gorbach D. ${ }^{2}$, Belousova M. ${ }^{1}$, Romanovskaya E. ${ }^{2}$, Lukasheva E. ${ }^{2}$, Lobov A. ${ }^{2,3}$, Ihling C. ${ }^{4}$, \\ Frolov A. ${ }^{2,4}$, Nizhnikov A. ${ }^{1,2}$, Antonets K. ${ }^{1,2}$ \\ ${ }^{1}$ Laboratory for Proteomics of SupraOrganismal Systems, All-Russian Research Institute of Agricultural Microbiology, Saint \\ Petersburg, Russia \\ ${ }^{2}$ Department of Biology, St. Petersburg State University, Saint Petersburg, Russia \\ ${ }^{3}$ Laboratory of Regenerative Biomedicine, Institute of Cytology, Russian Academy of Sciences, Saint Petersburg, Russia \\ ${ }^{4}$ Department of Pharmaceutical Chemistry and Bioanalytics, Institute of Pharmacy, Martin-Luther Universität Halle-Wittenberg, \\ Halle, Germany \\ *e-mail: yu.malovichko@arriam.ru
}

Key words: bacillus thuringiensis, biopesticides, toxins, genomics, proteomics, pathogenicity, virulence, specificity, oxford nanopore, illumina, orbitrap

Motivation and Aim: Bacillus thuringiensis, or Bt, is a Gram-positive spore-forming soil bacterium utilized in biologicals production due to its virulence to invertebrate pests. The molecular bases for its host specificity are attributed either to the proteinaceous toxins [1], or to minor virulence factors [2]. We performed whole genome sequencing (WGS) of four $B t$ strains belonging to different serovars followed by proteome mass-spectrometry (MS) in order to elucidate the impact of gene repertoire on the virulent properties.

Methods and Algorithms: Three virulent Bt strains and one avirulent derivate were used in this work. WGS sequencing was performed using Illumina HiSeq X and MinION platforms. The genome assembly was done by Flye assembler. For genome annotation, Prokka and CryProcessor [3] were used. For proteomic analysis, total protein fraction was extracted from vegetative and sporulating cultures. Qualitative analysis comprised of twodimensional difference gel electrophoresis followed by electrospray quadrupole time-of-flight MS. Quantitative proteomic assay was performed using high performance liquid chromatography and Orbitrap electrospray MS. Results: Obtained genomes were assembled up to replicon level. The repertoire of both Cry genes and minor virulence factors varied between stains. The loss of virulence in the avirulent strain was caused by an elimination of Cry genes. Qualitative proteomic assay revealed 21 differentially produced proteins. The interstrain comparisons at the respective stages revealed differences potentially involved in pathogenicity phenotypes at both stages.

Conclusion: The observed differences persist at the proteomic level in both vegetative and sporulating bacterial cultures and may underlie the patterns of the $B t$ strain diversification.

Acknowledgments: The proteomic part of this work was supported by the Russian Foundation for Basic Research, Project 20-316-70020.

\section{References}

1. Palma L, Muñoz D, Berry C, Murillo J, Caballero P. Bacillus thuringiensis toxins: an overview of their biocidal activity. Toxins (Basel). 2014;6(12):3296-3325. Published 2014 Dec 11. doi:10.3390/toxins6123296.

2. Malovichko YV, Nizhnikov AA, Antonets KS. Repertoire of the Bacillus thuringiensis Virulence Factors Unrelated to Major Classes of Protein Toxins and Its Role in Specificity of Host-Pathogen Interactions. Toxins (Basel). 2019;11(6):347. Published 2019 Jun 17. doi:10.3390/toxins11060347.

3. Shikov AE, Malovichko YV, Skitchenko RK, Nizhnikov AA, Antonets KS. No More Tears: Mining Sequencing Data for Novel Bt Cry Toxins with CryProcessor. Toxins (Basel). 2020;12(3):204. Published 2020 Mar 23. doi:10.3390/toxins12030204. 


\title{
In silico analysis of the $R 2 R 3-M y b, b H L H-M y c$ and WDR proathocyanidins regulatory genes in Gossypium genus
}

\author{
Mikhailova A. ${ }^{1,2 *}$, Strygina K. ${ }^{2}$, Khlestkina E.K. ${ }^{2}$ \\ ${ }^{1}$ Department of Genetics and Biotechnology, Faculty of Biology, Saint Petersburg State University, Saint Petersburg, Russia \\ ${ }^{2}$ Federal Research Center N.I. Vavilov All-Russian Institute of Plant Genetic Resources, Saint Petersburg, Russia \\ *e-mail: a.mikhailova@vir.nw.ru
}

Key words: brown cotton fibers, Gossypium, flavonoid biosynthesis, MBW complex, proanthocyanidins, regulatory genes

\begin{abstract}
Motivation and Aim: Flavonoids are essential secondary metabolites that are known to be responsible for plant tissue pigmentation. There are many studies concerning structural flavonoid biosynthesis genes in cotton (genus Gossypium L.), while regulation mechanisms that are supported by the MBW complex do not understand enough. For the first time, we conducted detailed analysis of the regulatory MBW genes involved in biosynthesis of flavonoid pigments proanthocyanidins (PAs) in cotton fiber.

Methods and Algorithms: The search of paralogous and homoeologous copies of the R2R3-Myb, bHLH$M y c$ and $W D R$ genes in diploid and allotetraploid cotton species was based on available sequences in the CottonFGD and NCBI databases. The promoter prediction was carried out with New PLACE software. The cluster analysis was performed using MEGA-X software and UPGMA algorithm with 1000 bootstrap replications and maximum composite likelihood method as a substitution model. Conservative domains were identified using Protein family database. Protein similarity determined by utilizing LALIGN tool. Presumable 3D-protein structures were modeled using SWISS-MODEL software. To align and provide the multiple comparison of 3D protein structures, PDBeFold service was used.

Conclusion: We characterized gene copies related to the R2R3-Myb, bHLH-Myc and WDR gene families in Gossypium genomes, taking into account those described earlier in A. thaliana L. We established that all identified gene copies among considering families, except for GhTT8-A2, could be involved in PAs biosynthesis. In promoter regions of regulatory genes numerous light, extreme temperature and phytohormones sensitive motifs, as well as specific motifs, were revealed. Evolution studies have suggested that the GhTTG1/GhTTG3 genes are the most conservative predominantly supported by selection, while GhTT2/GhMYB10 and GhTT8 are more variable so that they represent a particular interest for nextgeneration breeding of naturally colored cotton cultivars.

Acknowledgements: This work was conducted within the framework of the state task regarding to Theme № 0481-2019-0001 "Genomic and postgenomic technologies for searching for new genetic markers of economically important traits and new allelic variants of agricultural valuable genes in the gene pool of cultivated plants and their wild relatives".
\end{abstract}




\title{
The role of LMNB1 protein in replicative senescence of primary human fibroblasts
}

\author{
Morozova E. ${ }^{1 *}$, Laktionov P. ${ }^{1,2}$, Singh P. ${ }^{1,3}$ \\ 1 Novosibirsk State University, Novosibirsk, Russia \\ 2 Institute of Molecular and Cellular Biology, SB RAS, Novosibirsk, Russia \\ 3 Nazarbayev University School of Medicine, Nur-Sultan, Republic of Kazakhstan \\ *e-mail:morozovae613@gmail.com
}

Key words: senescence, lamin B1, CRISPR/Cas9

Motivation and Aim: Aging is a natural process that leads to a gradual decrease in the afunctional capabilities of the organism. Cellular senescence is tightly linked with general organism ageing, as senescent cells accumulate in body tissues with age. Senescent cells demonstrate characteristic morphological and metabolic changes. Cellular senescence is accompanied by large-scale spatial rearrangements of the nucleus leading to the formation of senescence-associated heterochromatin foci (SAHF) and senescence-associated distension of centromeres (SADS). A decrease in the level of the nuclear envelope component of lamin B1 leads to disruption of the chromatin structure and it is supposed to be involved in the mechanism of SAHF and SADS formation. Lamins take part in numerous regulatory cellular processes that influence cell proliferation, differentiation, and apoptosis. The aim of the work is to characterize the role of lamin B1 in replicative cellular senescence.

Methods and Algorithms: To generate primary human fibroblasts carrying the LMNB1 gene deletion we used CRISPR/Cas9 targeted mutagenesis. Guide RNAs were chosen using the CRISPR Design resource and cloned into PX459 vector. The efficiency of guide RNAs was determined using pEGxxFP system with following analysis by flow cytometry. Developed CRISPR/Cas9 targeted mutagenesis system was applied on LF1 primary lung fibroblasts cell strain.

Results: Genetic structures coding different guide RNAs to receive LMNB1 gene deletion by CRISPR/Cas9 were obtained. The efficiency of guide RNAs was determined by flow cytometry and the most effective were chosen for further work. Optimization of targeted mutagenesis conditions by the CRISPR/Cas9 method for removal of the coding region of the LMNB1 gene in primary human fibroblasts was carried out. A heterogeneous population of cells of primary human fibroblasts carrying the LMNB1 gene deletion was obtained. 


\title{
Creating the barcoded plasmid library to study the mechanisms of transgene integration
}

\author{
Muravyova A. ${ }^{1,2 *}$, Smirnov A. ${ }^{1}$, Battulin N. ${ }^{1,2}$ \\ ${ }^{1}$ Institute of Cytology and Genetics $S B$ of RAS, Novosibirsk, Russia \\ ${ }^{2}$ Novosibiorsk State University, Novosibirsk, Russia \\ *e-mail: a.muraveval@g.nsu.ru
}

Key words: DNA double-strand break repair, homologous recombination, non-homologous end joining, barcodes

Motivation and Aim: Genome editing approaches are based on the mechanisms of DNA reparation and recombination. Homologous recombination (HR) and non-homologous end joining (NHEJ) are considered to be two alternative pathways of double-strand breaks of genome DNA during editing (1). We previously showed that upon microinjection of DNA fragments into the pronucleus of the zygote, both pathways are involved in the processing of DNA ends (2). To study how Cas9 enzyme influence DNA repair mechanisms involved in transgene integration, we designed the experiment, in which creating the barcoded plasmid library was the key point. The unique sequences that flank the transgenes will allow us to study the detailed mechanism of transgene integration after the microinjection into the pronucleus of the zygote.

Methods and Algorithms: Our experiment demanded library diversity of $10^{5}$, so we designed oligonucleotides with 14 random positions. In the oligonucleotide mix all combinations of molecules were represented equally. To avoid GC-bias, two degenerated positions are changed with three certain bases. Theoretical diversity of these sequences is $4^{14}=2 \times 10^{8}$ - which is a thousand times more than the min required library diversity. We also took to consideration a probability of wrong barcode sequencing. For plasmid construction we used four fragments Gibson Assembly: two barcoded oligos to flank the transgene, the transgene fragment and the plasmid backbone. Then we used Top10 E.Coli cells for electroporation and large pallets to get the colonies. The volume of electroporation allowed to get approximately $2 \times 10^{5}$ colonies. Then the library was purified on maxi-prep columns.

Results: We got approximately 160000 unique colonies. 10\% of them contained the original plasmid backbone without transgene and barcodes. We analysed 30 randomly selected clones by the restriction digestion and following sequencing and found out only $6 \%$ of clones had mutations in plasmid. Sequencing also showed the randomness of included barcodes. The obtained library fits our research restrictions.

Conclusion: We created the barcoded plasmid library to study the mechanisms of transgene integration. Now we are preparing the library for NGS sequencing and pronuclear microinjections with Cas9 protein. Obtained animals will be genotyped. Integrated copies will also be NGS sequenced.

Acknowledgements: Supported by the RFBR (20-34-70087).

\section{References}

1. Mansour et al. Hierarchy of nonhomologous end-joining, single-strand annealing and gene conversion at sitedirected DNA double-strand breaks. Nucleic Acids Res. 2008.

2. Smirnov et al. DNA barcoding reveals that injected transgenes are predominantly processed by homologous recombination in mouse zygote. Nucleic Acids Res. 2020. 


\title{
Y-box-binding protein 1 as regulator of poly(ADP-ribose) polymerase 1 activity
}

\author{
Naumenko K.N.*, Sukhanova M.V., Alemasova E.E., Kurgina T.A., Kutuzov M.M., Lavrik O.I. \\ Institute of Chemical Biology and Fundamental Medicine SB RAS, Novosibirsk, Russia \\ *e-mail:k-naumenko@mail.ru
}

Key words: Y-box binding protein 1, base excision repair, poly(ADP-ribose)polymerase 1

Motivation and Aim: Base excision repair (BER) is one of the main DNA repair pathways is aimed at repairing the most common DNA damages such as single-strand breaks apurinic/apirimidinic (AP) sites or modified bases resulting from its oxidation, deamination or alkylation. The poly (ADP-ribose) polymerase 1 (PARP1) is considered as one of the key regulators of BER process. Despite the fact that several key proteins are sufficient for reconstruction in vitro BER reactions, it is currently believed that additional regulatory proteins can be involved in the BER in cells. One of these proteins is the multifunctional $\mathrm{Y}$-box binding protein (YB-1). YB-1 is a multifunctional protein involved in a lot of cellular processes. YB-1 is a DNA- and RNA-binding protein. By binding to nucleic acids, YB-1 is engaged in many DNA- and mRNA-dependent processes such as DNA replication and repair, transcription and mRNA translation. YB-1 has an increased affinity to damaged DNA and interacts in vivo and in vitro with several BER proteins, regulating their activities. Recently, it was shown that YB-1 also interacts with PARP1. The aim of present research was to investigate influence of YB-1 on PARP1 activity.

Methods: gel electrophoresis

Results: In the current work, using model DNAs carrying a various types of damage, we quantified the level of poly (ADP-ribose) (PAR) synthesized by PARP1 in the presence or absence of the regulatory protein YB-1. We found that effect of YB-1 on the activity of PARP1 is independent on the structure of the DNA substrates. Using a model nucleosome structure, we shown that PARP1 and YB-1 form a heteromeric complex and YB-1 is PARylated by PARP1, suggesting that YB-1 can be an acceptor of ADP-ribose in the context of chromatin. Using nuclear extracts from HeLa cells, we showed that the addition of YB-1 to the extract leads to increased level of poly(ADP-ribose) synthesis and prevented the PAR degradation. We suggest that YB-1 is able to mediate stress response by increasing the total yield of poly(ADP-ribose).

Conclusion: YB-1 might function as regulator of DNA damage-dependent PARP1 activation, acting on broad spectrum of DNA structures increasing the overall yield of poly(ADP-ribosyl)ation reaction.

Acknowledgements: The work was supported by the RFBR (18-04-00882). 


\title{
Application of single-cell Hi-C method for analysis of lampbrush chromosome conformation
}

\author{
Nurislamov A. ${ }^{1,2 *}$, Gridina M. ${ }^{2}$, Taskina A. ${ }^{1}$, Fishman V. ${ }^{1,2}$ \\ ${ }^{1}$ Novosibirsk State University, Novosibirsk, Russia \\ ${ }^{2}$ Institute of Cytology and Genetics SB RAS, Novosibirsk, Russia \\ *e-mail: a.nurislamov@g.nsu.ru
}

Key words: Hi-C, single-cell, lampbrush chromosomes, oogenesis

Motivation and Aim: Despite being discovered in late 19th century, lampbrush chromosomes' structure is still not well studied: most of the lateral loops have not yet been mapped and the study of their threedimensional organization by microscopic methods does not allow precise identifying of molecular mechanisms involved in their formation $[3,4]$. The rapid improvement of methods for capturing the spatial conformation of chromosomes (3C) in recent years has significantly expanded the range of their application and also made it possible to conduct a deeper analysis at the level of individual cells [1]. Such single-cell techniques allow to reveal heterogeneity in chromatin conformation within populations of the same cell type [2] and require less input material to work with. Here, we aimed to adopt single-cell Hi-C method for studying chromatin interactions in a developing oocyte nucleus.

Methods and Algorithms: Nuclei were extracted from chicken oocytes as described in [3]. Hi-C libraries were prepared by using modified version of protocol shown in [2]. Libraries were sequenced by Illumina. NGS data was analyzed to construct Hi-C maps.

Results: As shown by microscopic methods, fixation of nuclei preserves specific spatial organization of lampbrush chromatin, which indicates that $\mathrm{Hi}-\mathrm{C}$ could be used to infer native chromatin structure. Analysis of NGS data in some samples revealed the absence of whole chromosomes and the presence of a large number of reads that do not align with the chicken genome. In samples where these issues weren't present, two types of Hi-C maps were visually noticed - with a high and low proportion of trans-contacts. For most of the analyzed nuclei we observed a noticeable drop of the contact frequencies for loci separated by more than $1-2 \mathrm{Mb}$.

Conclusion: Experimental data show that the single-cell Hi-C method can be applied to analyze the conformation of lampbrush chromosomes. Further analysis requires optimization of protocol workflow and bioinformatics algorithms.

Acknowledgements: This project was supported by the RSF grant 20-64-46021.

\section{References}

1. Nagano T. et al. Single-cell Hi-C for genome-wide detection of chromatin interactions that occur simultaneously in a single cell. Nature Protocols. 2015;10(12):1986.

2. Nagano T. et al. Single-cell Hi-C reveals cell-to-cell variability in chromosome structure. Nature. 2013;502(7469):5964.

3. Zlotina A. et al. Microdissection of lampbrush chromosomes as an approach for generation of locus-specific FISH-probes and samples for high-throughput sequencing. BMC Genomics. 2016:17(1):126.

4. Zlotina A. et al. New insights into chromosome organization provided by lampbrush chromosome microdissection and high-throughput sequencing. Frontiers Genetics. 2020;11:57. 


\section{Are short sequence repeats (SSRs) pinpoint evolution hotspots? Cyprinidae fish case study}

Orlov M.A. ${ }^{1 *}$, Tykhonov A.Yu. ${ }^{2}$

${ }^{I}$ Institute of Cell Biophysics of RAS, Poushchino, Russia

2 “AquaLogo” group company, Moscow, Russia

*e-mail: orlovmikhailanat@gmail.com

Key words: Cyprinidae, SSRs, genomics, fish

Motivation and Aim: Short sequence repeats or SSRs are repeated DNA kinds with units 1 to 6 nucleotide long which are strictly adjacent. Length and sequence purity (e.g. lack of irregularities) were earlier found to collocate with a variety of genome hotspots, such as chromosome rearrangement loci or loci under strict selection. Here we consider SSR sets for Cyprinidae fish species. Length of SSRs as well as their oligonucleotide composition that we obtained differ clearly in domesticated vs free-living representatives. Cyprinidae are unique in their dramatic evolutionary history with complex polyploidy, distant hybridization as well as massive chromosome rearrangements events [1]. The family therefore is very well suited for studying SSRs evolution in general. Genes encoding traits under strict selection were shown to have SSRs length well correlated with the traits quantity [2]. SSRs are prone to mutate most rapidly, e.g. undergoing expansions (i.e. trinucleotide expansions) as well as contractions. These are connected with the rate of various evolutionary processes [3].

Methods and Algorithms: Here we consider SSRs for 28 Cyprinidae fish (including most notable goldfish Carassius auratus) deposited in FishMicrosat database [4]. For each species SSRs set we derived length in base pair and nucleotide composition. Namely, di-, tri- and tetranucleotide frequency was obtained. The result was furtherly interrogated using Ward's method clusterization and principal component analysis (PCA).

Results: Rather expectedly, domesticated fish mostly clustered together. So did the free-living species. PCA reinforced clusterization results while also pointing to significant differences between two clusters in sequence. Indeed, TG/CA dinucleotide presented more in domesticated fish with smaller amounts of AG/TC dinucleotide. The fact agrees with previous data of TG being more mutagenic.

Conclusion: The hereby obtained results drive attention to the Cyprinidae including goldfish as a valuable study subject for the aim of SSRs connection to evolution as well as breeding. Preliminary data suggest notable patterns of longer TG-rich simple sequence repeats in domesticated species.

\section{References}

1. Boron A., Spoz A., Porycka K. et al. Comparative Cytogenetics. 2014, V. 8(3), P. 233-248.

2. Fondon J. W., Garner H. R. 2004, V. 101(52), P. 18058-18063.

3. Xie K. T., G. Wang, A. C. Thompson et al. Science. 2019. V. 363. P. 81-84

4. Nagpure N.S., Rashid I., Pati R. et al. BMC Genomics. 2013, V. 14, P. 630. 


\title{
Polymorphisms in $F A D 3 A$ and $F A D 3 B$ genes that determine the fatty acid composition of flax oil
}

\author{
Povkhova L.V. ${ }^{1,2 *}$, Kezimana P. ${ }^{1,3}$, Krasnov G.S. ${ }^{1}$, Novakovskiy R.O. ${ }^{1}$, Pushkova E.N. ${ }^{1}$, \\ Rozhmina T.A. ${ }^{1,4}$, Dmitriev A.A. ${ }^{1}$, Melnikova N.V. ${ }^{1}$ \\ ${ }^{1}$ Engelhardt Institute of Molecular Biology, Russian Academy of Sciences, Moscow, Russia \\ ${ }^{2}$ Moscow Institute of Physics and Technology, Dolgoprudny, Russia \\ ${ }^{3}$ Peoples' Friendship University of Russia (RUDN University), Moscow, Russia \\ ${ }^{4}$ Federal Research Center for Bast Fiber Crops, Torzhok, Russia \\ *e-mail:povhova.lv@phystech.edu
}

Key words: Linum usitatissimum L., flax, FAD3, fatty acids, deep sequencing, HRM

Motivation and Aim: Flax (Linum usitatissimum L.) is an important crop that is grown for fiber and seed. Seeds are used for oil production that has a wide range of applications: pharmaceuticals, food, feed, paints, varnishes, etc. Directions of flax oil use are determined by the ratio of fatty acids, mainly linolenic (omega3 ) and linoleic (omega-6) ones. It is known that genes of FAD3 (fatty acid desaturase 3) family play a key role in fatty acid synthesis by catalyzing the conversion of linoleic acid into linolenic one. The purpose of our study was to reveal polymorphisms in FAD $3 A$ and $F A D 3 B$ genes that determine the fatty acid composition of flax oil and to develop a test system for their identification.

Methods and Algorithms: A representative set of 84 flax cultivars and lines with different fatty acid composition was provided by the Institute for Flax (Torzhok). DNA was extracted from 40-50 seedlings for each cultivar/line, and two-staged PCR was performed for library preparation. Full-length sequences of $F A D 3 A$ and $F A D 3 B$ genes were determined using deep sequencing on MiSeq (Illumina, USA) with $300+300$ bp reads. VarScan variant caller was used for revelation of polymorphisms in the studied genes. High resolution melting (HRM) analysis with pre-amplification was performed on a Rotor-Gene Q realtime PCR cycler (Qiagen, Netherlands) for identification of single nucleotide polymorphisms (SNPs) of interest.

Results: On sequencing, average coverage of 300x was obtained for FAD3 genes that enabled accurate identification of polymorphisms. Using VarScan, 91 and 62 polymorphisms were identified in FAD $3 A$ and $F A D 3 B$ genes respectively. Correlation analysis revealed SNPs that were associated with the content of fatty acids in flax oil. Further detailed analysis showed that samples with both the tryptophan to stop codon substitution in FAD3A and the histidine to tyrosine substitution in $F A D 3 B$ had a low level of linolenic acid, while all cultivars and lines without these mutations were high-linolenic. Samples with only one of these mutations had medium content of linolenic and linoleic acids. Another important mutation in FAD $3 A$ resulting in arginine to stop codon substitution was identified only in one low-linolenic cultivar from the analyzed collection. HRM-based test system was developed for identification of these three polymorphisms. Homozygous and heterozygous states for analyzed SNPs were distinguished clearly by temperature shift in melt curves.

Conclusion: Analysis of the deep sequencing results revealed three polymorphisms in FAD $3 A$ and FAD $3 B$ genes that determine the ratio of linolenic and linoleic acids. An HRM-based test system for identification of these key SNPs can increase the efficiency of breeding cultivars with the targeted content of fatty acids in flax oil.

Acknowledgments: This work was funded by RFBR according to the research project 17-29-08036. 


\section{Using fast homology search tools for protein sequence functional annotation: a comparison}

Pronozin A.*, Genaev M., Afonnikov D.

Institute of Cytology and Genetics SB RAS, Novosibirsk, Russia

*e-mail: pronozinartem95@gmail.com

Key words: sequence functional annotation, GO terms, semantic similarity

Motivation and Aim: Annotation of the protein sequences by homology search and GO term transfer from highly homologous sequences is an important task for current genome and transcriptome sequencing projects. However, large size of sequence databases make homologous sequence search difficult in reasonable time. There exist tools that apply fast and ultrafast database search algorithms to find sequence homologs. We compare performance of the highly homologous sequence detection by several fast search tools applied for A.thaliana protein sequences represented in OrthoDB database with the sequence ranking obtained by ClustalW.

Methods and Algorithms: 27,636 sequences of the A. thaliana proteins from TAIR v10 [1]. We used orthologous genes from other organisms, as query homologs, which perform similar functions. The orthologous sequences identified from the OrthoDB database v10 [2]. We selected 9193 (contain 8,522,503 sequences) orthogroups containing A. thaliana proteins. Programs: BLASTP, BLASTP-fast, Diamond, Usearch ('ublast', 'usearch_local'), Mmseq2 were compared with sequence ranking obtained by ClustalW. For sequence list comparison, we used F1 and MAPK metric, compared the similarity of the GO terms associated with homologous hits by mens of semantic similarity (SS).

Results: The best values of performance metrics for single best hit observed for BLASTP (0.95). The performance decreased at $\mathrm{k}=5(0.75)$ and increased again to 0.80 at $\mathrm{k}=6-10$. These trends are similar for all tools. The result gene ontology (GO) comparison using F1 metric shows high similarity of the GO lists at $\mathrm{k}=1-10(0,97)$. Semantic similarity measure has almost no dependence on $\mathrm{k}$ for all gene ages. Computing time comparison demonstrated that Diamond have the smallest search time and the next is usearch_local method from Usearch.

Conclusion: To summarize, our results demonstrate that the optimal number of hits returned by fast search program for the functional annotation of the query sequence is 10 . The fast homology search tools are able to identify true best hits from large databases within $\mathrm{k}$ up to 20 with sufficient accuracy.

Acknowledgements: Supported by Russian Science Foundation grant 18-14-00293. The computational resources of the Joint HPC Facility 'Bioinformatics' was used with the support of the budget project No. 0324-2019-0040-C-01.

\section{References}

1. Mustafin Z. et al. Phylostratigraphic Analysis Shows the Earliest Origination of the Abiotic Stress Associated Genes in A. thaliana. Genes. 10.12, pp. 963, 2019.

2. Kriventseva E. et al. OrthoDB v10: sampling the diversity of animal, plant, fungal, protist, bacterial and viral genomes for evolutionary and functional annotations of orthologs. Nucleic Acids Research. 47.D1, pp. D807-D811, 2019. 


\title{
High-quality genome assemblies of male and female Populus $\mathbf{x}$ sibirica plants
}

\author{
Pushkova E.N. ${ }^{1 *}$, Krasnov G.S. ${ }^{1}$, Dvorianinova E.M. ${ }^{1,2}$, Novakovskiy R.O. ${ }^{1}$, Povkhova L.V. ${ }^{1,2}$, \\ Melnikova N.V. ${ }^{1}$, Dmitriev A.A. ${ }^{1}$ \\ ${ }^{1}$ Engelhardt Institute of Molecular Biology, Russian Academy of Sciences, Moscow, Russia \\ ${ }^{2}$ Moscow Institute of Physics and Technology, Dolgoprudny, Russia \\ *e-mail: pushkoval8@gmail.com
}

Key words: Populus; poplar; sex determination, de novo genome assembly; Nanopore; pure high-molecular-weight DNA

Motivation and Aim: Dioecy, i.e. the presence of males and females, is widespread among animals, but in plants, it is much less common - only 5\% of angiosperms are dioecious. The genus Populus is represented by dioecious species with XY or ZW sex-determination system and is characterized by polymorphic mechanisms of sex determination. $P . \times$ sibirica is one of the most common poplars in the Moscow region, but there is no genome assembly for it to date. Our aim was to achieve high-quality genome assemblies of male and female plants of $P$. x sibirica. We used a combination of the Oxford Nanopore Technologies (ONT) platform with long reads and the Illumina platform with high-accuracy reads.

Methods and Algorithms: Leaves were collected from male and female plants of $P$. x sibirica in the period of poplar bloom for the proper sex identification and immediately frozen in liquid nitrogen. We developed and optimized the protocol of obtaining pure high-molecular-weight genomic DNA from young poplar leaves and received DNA samples with approximately $50 \mathrm{~kb}$ length, A260/A280 of 1.7-2.0, and A260/A230 of 2.0-2.2. DNA libraries were prepared and sequenced on MinION (ONT) with FLO-MIN-106 R9.4 and FLO-MIN-106 R10 flow-cells (ONT) and HiSeq 2500 (Illumina) with a read length of 125+125 bp. Nanopore reads were processed using Guppy 3.6.1. Then, adapter sequences were removed using Porechop. Low-quality Nanopore and Illumina reads were filtered out and/or trimmed using Trimmomatic. Genome assemblies were performed using four assemblers: Flye 2.8, Raven 1.1.10, Shasta 0.5, and wtdbg2 2.5. Then, polishing was performed with Racon 1.4.3 using Nanopore reads and with POLCA from MaSuRCA 3.3.9 using Illumina reads.

Results: After sequencing on MinION, we received $22.3 \mathrm{~Gb}$ and $22.9 \mathrm{~Gb}$ with N50 about $20 \mathrm{~kb}$ for male and female plants respectively, while the use of HiSeq 2500 in 2x125 bp format resulted in 36 million reads and 52 million reads for the same plants. The best result was obtained for the Raven assembler: genome length was $474 \mathrm{Mb}$ with $\mathrm{N} 50$ of $0.33 \mathrm{Mb}$ for the male poplar and $495 \mathrm{Mb}$ with $\mathrm{N} 50$ of $0.32 \mathrm{Mb}$ for the female one. According to BUSCO, the completeness of genomes was $96.8 \%$ for the male and $97.9 \%$ for the female.

Conclusion: The combination of Nanopore and Illumina platforms allowed us to achieve a high-quality genome assembly of male and female plants of $P$. x sibirica that will provide an opportunity to compare the received data with the genome assemblies of genetically different poplars and to clarify the mechanism of poplar sex determination.

Acknowledgements: This work was funded by RFBR according to the research project 17-29-08036. 


\title{
Development of DNA markers to create resistant barley varieties based on assisted genomic loci identification
}

\author{
Rozanova I. ${ }^{1,2 *}$, Lashina N. ${ }^{3}$, Afanasenko O. ${ }^{3}$, Khlestkina E. ${ }^{1,2}$ \\ ${ }^{1}$ N.I. Vavilov All-Russian Research Institute of Plant Genetic Resources (VIR), St. Petersburg, Russia \\ ${ }^{2}$ Institute of Cytology and Genetics, Siberian Branch of the Russian Academy of Sciences, Novosibirsk, Russia \\ ${ }^{3}$ All-Russian Research Institute for Plant Protection, St. Petersburg, Russia \\ *e-mail: i.rozanova@vir.nw.ru
}

Key words: association mapping, barley, GWAS, Hordeum vulgare, spot blotch, resistance, SNP

Motivation and Aim: Barley genetics has a long history of identifying markers and is among the oldest model species for genetic analysis. To date, modern breeding includes technologies based on the using DNA markers. In recent years, GWAS analysis has been used to massively search for associations between phenotype and genotype. Disease resistant breeding programs are an effective way to control the disease, because it is one of the factors limited the quality yield. SNP identification that associated with the disease and converting them into convenient markers for DNA screening significantly facilitates breeding programs aimed at developing resistant varieties. The goal of the current study is to reveal genomic loci, associated with resistance to main fungal barley disease such spot blotch and subsequent development of the new diagnostic DNA-markers of breeding significant loci associated with resistance.

Methods and Algorithms: The genome-wide association was performed on Siberian spring barley collection consisted from the 94 of barley varieties and lines with aim to identify markers to Cochliobolus sativus pathogen caused such barley disease as spot blotch. The research of population structure showed that the collection includes four groups containing 17, 29, 20, and 34\% of the genotypes in each. Three pathogen isolates (Ch3, $\mathrm{Kr} 2$ and $\mathrm{O} 18.2)$ were used for plant resistance identification. Five genomic loci associated to C. sativus pathogen on the $1 \mathrm{H}, 2 \mathrm{H}, 3 \mathrm{H}, 5 \mathrm{H}$ and $7 \mathrm{H}$ chromosomes were detected.

Conclusion: The validation on independent collection that consisted from 22 barley accessions contrasted to $C$. sativus pathogen resistance allows to develop 4 DNA markers (on the third chromosome) that can be used as diagnostic in the breeding spot blotch resistant varieties. 


\title{
Photosynthesis of the isogenic lines Triticum aestivum $\mathrm{L}$.
}

\author{
Semilet T.V. ${ }^{1 *}$, Silantyeva M.M. ${ }^{2}$, Khlestkina E.K. ${ }^{1}$ \\ ${ }^{I}$ Federal Research Center the N.I. Vavilov All-Russian Institute of Plant Genetic Resources (VIR), St. Petersburg, Russia \\ ${ }^{2}$ Altai State University, Barnaul, Russia \\ *e-mail:semilet_tatyana@mail.ru
}

Key words: photosynthesis, quantum yield $\mathrm{Y}_{(\mathrm{II})}$, electron transport rate (ETR), isogenic lines

Motivation and Aim: Currently the searching and mapping of gene loci are widely use in molecular genetics. The expression of genes influences on the operation of photosystems and other physiological processes in higher plants. The photosyntesis influences good yield of wheat. The soft wheat (Triticum aestivum L.) is an important object for these studies. Wheat is known to be occupy the largest cultivated areas among other cereals in the world. Analysis of chlorophyll fluorescence parameterswas conducted for the initial and the isogenic lines of soft wheat (i:S29Pp-Alpp-D1pp3, i:S29Pp-A1Pp-D1Pp3PF, i:S29Pp-A1Pp-D1pp3P, i:S29Pp-A1pp-D1Pp3P, i:S29Pp-Alpp-D1Pp3PF, i:S29Pp-A1Pp-D1pp3PF, i:S29pp-Alpp-D1pp3, i:S29Pp-A1Pp-DIPp3P). We established the relationship between the intensity of the photosystems and the genotype.

Methods and Algorithms: The parameters of chlorophyll fluorescence were measured by PAM- fluorimetr JUNIOR-PAM (Walz, Germany) during all stages of ontogeny. The objects of the study included the recurrent cultivar of soft wheat - Saratovskaya-29 and its isogenic lines. This isogenic lines were obtained from the donor varieties (Purple Feed and Purple). The material for the study and genetic maps was kindly provided by The Federal Research Institute of Cytology and Genetics (Novosibirsk, Russia) [2].

Results: The isogenic line-iPF2A had high and stable parameters of quantum yield and electron transport rates among other objects. The results obtained for S-iPF2A were associated with a marker Xgwm372 [1], which was inherited from the donor T. aestivum Purple (Pp3). We associated the genes expression the marker Xgwm372 with influence on a fluorescence of chlorophyll and a pigment count at different developmental stages (locus Qchc.iiwbr-2A) [1].

Conclusion: We got results of data photosyntesis for isogenic lines of soft wheat Saratovskaya-29 using method PAM-fluorimetry. The locus gene on chromosome 2A was identified based on the available published data. The transformation of this locus may changes the work of photosynthetic apparatus.

Acknowledgements: This work was conducted within the framework of the state task regarding to Theme No. 0481-2019-0001 "Genomic and postgenomic technologies for searching for new genetic markers of economically important traits and new allelic variants of agricultural valuable genes in the gene pool of cultivated plants and their wild relatives".

References

1. Bhusal N. et al. Mapping QTLs for chlorophyll content and chlorophyll fluorescence in wheat under heat stress. Biologia Plantarum. 2018;62(4):721-731.

2. Tereschenko O.Y. et al. The D Genome Carries a Gene Determining Purple Grain Colour in Wheat. Cereal Research Communications. 2012;40(3):334-341. 
DOI 10.18699/SBB-2020-35

\section{Genes determining dwarfism in Cucurbitaceae}

Strygina K.*, Tekhanovich G., Elatskova A., Elatskov Yu., Khlestkina E.

Federal Research Center N. I. Vavilov All-Russian Institute of Plant Genetic Resources, Saint Petersburg, Russia

*e-mail: k.strygina@vir.nw.ru

Key words: Citrullus, Cucumis, Cucurbita, dwarf genes, short vine

Motivation and Aim: The melon crops (family Cucurbitaceae), such as pumpkin (genus Cucurbita), muskmelon (genus Cucumis), and watermelon (genus Citrullus) are both heat and light preferring plants. These crops are widely distributed on the territory of Russia and are cultivated as food and feed plants. Using methods of molecular genetics in combination with marker-assisted selection, it is possible to create dwarf varieties growing in more northern latitudes, including beyond the Arctic Circle. The aim of this work is to identify and mark the genes responsible for the formation of dwarf plant forms based on the unique collection of melon crops of the Federal Research Center N. I. Vavilov All-Russian Institute of Plant Genetic Resources (VIR).

Methods and Algorithms: The search of homologous sequences was made in CuGenDB database BLASTN. The cluster analysis using the MEGA software was based on NJ algorithm. Development of diagnostic primers for the alleles determination as well as primers for the PCR and sequencing was performed using the OLIGO program. A total of 13 C. lanatus varieties were studied.

Results: In genomes of watermelon C. lanatus, cucumber $C$. sativus, muskmelon $C$. melo, pumpkins and squashes C. pepo, C. moschata, C. maxima, C. argyrosperma, wax gourd Benincasa hispida, bottle gourd Lagenaria siceraria the search of homologous sequences of watermelon dwarf genes Cla010337 (ABC transporter), Cla010726 (gibberellin 20-oxidase) and Cla015407 (gibberellin 3-beta-hydroxylase) was performed. In genomes of analyzed organisms one copy of Cla010337, one copy of Cla010726 and two copies of Cla015407 were identified. Time of occurrence of each new copy is calculated and presented in the report. The allelic polymorphism was analyzed in genomes of VIR watermelon varieties.

Conclusion: All available sequences have conserved domains. Significant change in the motives, which could lead to changes in gene function, has been identified during sequencing in varieties with short vine. Acknowledgements: The present study was supported by the VIR project No. 0481-2019-0001. 


\title{
Erythrocytes 3D genome organization in vertebrates
}

\author{
Taskina A. ${ }^{1,2 *}$, Ryzhkova A. ${ }^{2}$, Khabarova A. ${ }^{2}$, Fishman V. ${ }^{1,2}$, Battulin N. ${ }^{1,2}$ \\ ${ }^{1}$ Novosibirsk State University, Novosibirsk, Russia \\ ${ }^{2}$ Institute of Cytology and Genetics SB RAS, Novosibirsk, Russia \\ *e-mail: a.taskina@g.nsu.ru
}

Key words: 3-dimensional nuclear organisation, Hi-C, erythrocytes, vertebrates

Motivation and Aim: 3-dimensional organization is essential for genome folding and compactization. It has been shown that progression through mitosis is accompanied by spatial rearrangement of the chromatin. This process could be studied using Hi-C technique, which shows genome-wide gain of spatial interaction between loci located $\sim 10 \mathrm{Mb}$ away from each other during mitotic prophase [1]. Previously we found that the same feature of spatial organization is also present in Hi-C maps of chicken erythrocytes that are in G2 phase [2]. Mechanism of formation and conservativeness in evolution of this phenomenon remain unknown. To resolve this issue, we investigated Hi-C data of blood cells in different classes of vertebrates. Methods and Algorithms: We used publically available erythrocyte Hi-C data of blood samples from fugu and catfish (bony fish), toads (amphibians), monitor lizard and sea turtle (reptilians), chicken and cassowary (birds). For human and mouse, nucleated terminal differentiation erythroid cells were used (unpublished data provided by R.A and A.A). Hi-C contacts were obtained using Juicer and processed with cooler software. We selected scaffolds longer than $9 \mathrm{Mb}$ and computed the contact frequency $(\mathrm{P})$ as a function of genomic distance (s), the $\mathrm{P}(\mathrm{s})$ function using cooltools expected function.

Results: The mitotic-like long-range interactions are clearly visible on Hi-C maps of amphibians, reptilians, mouse and bird. In accord with this, we observed the local peak of $\mathrm{P}(\mathrm{s})$ curve for these data, as well as for mammalian samples. Position of the peak varies from $20 \mathrm{Mb}$ in birds to $30 \mathrm{Mb}$ in amphibians. We didn't find the presence of the the peak in fish. Also, using chicken data we found that the local peak of $\mathrm{P}(\mathrm{s})$ curve is present only in the first five and the $\mathrm{Z}$ chromosomes, which are larger than $40 \mathrm{Mb}$. Position of the peak is constant in these six chromosomes.

Conclusion: Constant position of the peak in different long chromosomes data suggests a general mechanism explaining formation of the long-range mitotic-like interactions. Whether short chromosomes are packed in a different manner, or current method can not resolve the peak due to smaller number of faraway loci remains to be answered. The mitotic-like feature presents in erythrocytes among each considered class, besides bony fish. This could be explained by smaller size of bony fish chromosomes (less than $40 \mathrm{Mb}$ ).

Acknowledgements: This work was supported by RFBR grant \# 18-04-00668 A.

\section{References}

1. Gibcus JH, Samejima K, Goloborodko A et al. A pathway for mitotic chromosome formation. Science. 2018;359(6376):eaao6135. doi:10.1126/science.aao6135

2. Fishman V, Battulin N, Nuriddinov M et al. 3D organization of chicken genome demonstrates evolutionary conservation of topologically associated domains and highlights unique architecture of erythrocytes' chromatin. Nucleic Acids Res. 2019;47(2):648-665. doi:10.1093/nar/gky1103 


\title{
Development of a test system for evaluating the antiglycative effect of bioactive substances of medicinal plants
}

\author{
Vashurina N.V. ${ }^{1 *}$, Dubrovskii Y.A. ${ }^{2,3}$, Soboleva A.V. ${ }^{1,4}$, Frolov A.A. ${ }^{1,4}$ \\ ${ }^{I}$ Department of Biochemistry, Saint Petersburg State University, Saint Petersburg, Russia \\ ${ }^{2}$ Department of Chemistry, Saint Petersburg State University, Saint Petersburg, Russia \\ ${ }^{3}$ Almazov National Medical Research Centre, Saint Petersburg, Russia \\ ${ }^{4}$ Department of Bioorganic Chemistry, Leibniz Institute of Plant Biochemistry, Halle (Saale), Germany
}

Key words: protein glycation, medicinal plants, incubations

Motivation and Aim: Protein glycation and formation of advanced glycation end products (AGEs) essentially impact on complications of diabetes mellitus, pathogenesis of Alzheimer's disease and cancer. In this context, chemical substances, inhibiting protein glycation might be promising, anti-diabetic and neuroprotective agents. Indeed, to date several anti-glycative drugs, such as aminoguanidine, have been shown to be effective in therapy of diabetes complications. However, these drugs are highly toxic, that limits their clinical application. In this context, plant natural products, isolated from medicinal plants offer a rich source of new promissing candidates for pharma- and nutraceutical agents, able to inhibit AGE formation. However, for fast and efficient screening of extracts, fractions and individual compounds, and adequate reproducible and high-through test system is necessary.

Methods and Algorithms: The proposed test system will rely on in vitro incubations $(1,3,7,14$ and 21 days) of plant extracts and individual natural products with Maillard reaction mixtures. These mixtures will contain $0.5 \mathrm{mmol} / \mathrm{L} D$-glucose in sodium phosphate buffer $(\mathrm{pH} 7.2)$ and equimolar amounts of model synthetic peptides Ac-AFGSAKASGA-NH $\mathrm{N}_{2}$ and Ac-AFGSARASGA-NH $\mathrm{N}_{2}$ used in the previous work [1]. The progress of glycation can be followed by accumulation of individual AGEs at defined glycation sites, using liquid chromatography, coupled on-line to mass spectrometry (LC-MS). The applicability of the test system for determination of anti-glycative effects will be verified with aqueous and ethyl acetate extracts $(n=4)$ of the aerial parts of Geum rivale taken at a non-cytotoxic concentration of $33.3 \mu \mathrm{g} / \mathrm{ml}$. Thereby, the compounds with known anti-glycative effect rosmarinic acid at the concentration of $0.4 \mathrm{mg} / \mathrm{mL}$ and aminoguandine at the concentration of $5 \mathrm{mmol} / \mathrm{L}$ will be used as reference compounds.

Conclusion and outlook: At the next step, a representative set of medicinal plants will be tested. For this, 22 Astragalus species, collected from different regions of Uzbekistan will be considered. Methanolic extracts will be prepared and analyzed by UHPLC-QqTOF-MS in parallel to screening for anti-glycative effects. Prior to the probing anti-AGE properties, maximal non-toxic extract concentration will be determined in cell viability tests (3-(4,5-dimethylthiazol-2-yl)-2,5-diphenyltetrazolium bromide (MTT) assay) with SH-SY5Y human neuroblastoma cells using established methods [2].

\section{References}

1. Bilova T. et al. J. Biol. Chem. 2016. 291. 7621-7636.

2. Leonova T. et al. Int. J. Mol. Sci. 2020. 21. 


\title{
Development of regulatory loop for the quantitative control of gene expression
}

\author{
Vasilev R.A. ${ }^{1,2 *}$, Polushkina I.D. ${ }^{1,3}$ \\ ${ }^{1}$ National Research Center «Kurchatov Institute», Moscow, Russia \\ ${ }^{2}$ Lomonosov Moscow State University, Moscow, Russia \\ ${ }^{3}$ D.Mendeleev University of Chemical Technology of Russia, Moscow, Russia \\ *e-mail: ruavasilev@gmail.com
}

Key words: artificial circuits, RNA-switch, regulatory loop, intein splicing, RNA interference

Motivation and Aim: Gene therapy methods development has a great potential in medicine applications due to the ability to influence the etiological factors of diseases caused by mutations. In the same time there are an amount of nosologies etiology of those is based on quantitative changes in expression of particular genes. In this order development of integrated to genome targeted quantitative gene expression regulation tools is a worthy of note way to the therapy of the particular diseases. Hereditary hypercholesterolemia which is caused by apolipoprotein B (apoB) transcripts amount's bias is one of such diseases instances[1]. To modulate apoB expression we are planning to assemble a closed feedback system with posttranscriptional regulation of apoB.

Methods and Algorithms: We are developing 2 model systems. The first one can be represented as a feedback loop with an apoB-100 expression level posttranscriptionally regulated by interference with miRNA. In turn miRNA transcription can be initiated in the presence of chimeric transcription factor StdCas9-VP64. Translation of this TF will happen only in the case of additional activation: 5'-end secondary structure destabilization of mRNA. This can be achieved by introduction of toehold-like RNAswitch directly upstream of IRES in 5'-UTR of StdCas9-VP64. Expressed apoB-100 transcripts play translation activators role «unwrapping» the RNA-switch. In the second model system we offer to utilize intein splicing in trans instead of the RNA-switch. Using CRISPR/Cas it is possible to fuse 5'UTR of apoB100 with N-terminal domain of chimeric TF flanked by N-intein. C-terminal domain of StdCas9-VP64 with $\mathrm{C}$-intein will be expressed constitutively. As a result we are going to obtain closed multicomponent system with a feedback loop. To test the obtained RNA-switch for translation regulation capability we assembled genetic construction which encode RNA-switch and downstream-located EGFP gene and tried it in the coupled in vitro transcription |translation system [2].

Results: Genetic constructions with RNA-switch and inteins were assembled. RNA-switch was shown to implement translation regulation in the expected manner: in the absence of trigger mRNA ( $5^{\prime}$-UTR of ApoB mRNA) EGFP production was inhibited in the coupled in vitro transcription।translation system, on the other hand EGFP protein level was observed to be analogous to positive control (EGFP native mRNA).

Conclusion: Current results suggest that developed RNA-switch can be utilized as translation regulation tool and can be further used in mammalian cell-culture studies.

Acknowledgements: Supported by the RFBR (No. 18-29-07046).

\section{References}

1. Vega G. L. et al. In vivo evidence for reduced binding of low density lipoproteins to receptors as a cause of primary moderate hypercholesterolemia. Journal Clinical Investigation. 1986. V. 78. №. 5. P. 1410-1414.

2. Pelham H. R. B., Jackson R. J. An efficient mRNA-dependent translation system from reticulocyte lysates. European Journal Biochemistry. 1976. V. 67. №. 1. P. 247-256. 


\title{
Molecular dynamic and kinetic characterization of Cas9 mutants for improving specificity of genome editing tools
}

\author{
Vokhtantsev I. ${ }^{1,2 *}$, Kadtsyn E. ${ }^{2,3}$ \\ ${ }^{1}$ Institute of Chemical Biology and Fundamental Medicine SB RAS, Novosibirsk, Russia \\ ${ }^{2}$ Novosibirsk State University, Novosibirsk, Russia \\ ${ }^{3}$ Voevodsky Institute of Chemical Kinetics and Combustion SB RAS, Novosibirsk, Russia \\ *e-mail: ivanvohtancev@gmail.com
}

Key words: CRISPR/Cas9, molecular dynamics, genome editing

Motivation and Aim: Rational design was widely used to improve Cas9 genome editing tools in the last decade. In this approach amino acids, involved in stabilization of non-target strand DNA or destabilization of sgRNA/DNA, was mutated to increase a specificity of CRISPR/Cas9 system. Molecular dynamics (MD) data can elucidate thermodynamic aspects of interaction between amino acids and heteroduplex. We decided to find mutants that destabilize heteroduplex and then characterize them using MD and cleavage kinetics measurements to obtain more specific Cas9 variants.

Methods and Algorithms: The structure of the Cas9/sgRNA/DNA complex from [2] was used for molecular dynamics. The simulation was carried out in the Gromacs 5.1.2 package, at 300K and 1 bar. Force fields were used: ff14sb for protein, OL15 for DNA, OL3 for RNA, for water tip3p model was chosen, the charge was neutralized with sodium ions. The MD trajectory length was $100 \mathrm{~ns}$; a $30 \mathrm{~ns}$ segment was used for analysis. The energies of interaction of individual amino acids with the sgRNA/DNA heteroduplex were estimated within the APBS approach using the g_mmpbsa program. Recombinant Cas9 protein, sgRNA, and radiolabeled duplexes with/without mismatch $(4,9,14,18 \mathrm{bp}$ mismatch) were obtained for kinetic characterization. Single-turnover kinetics was carried out with 40 -fold excess over substrate by duplex addition. Cas9 point mutants have also been simulated (K163A, F164A, R403A, K918A) and characterized in the same conditions.

Results: After first round MD simulation, amino acids (K163, F164, R403, K918) with different energies of interaction were chosen for substitution into alanine and further simulation. As a result, the total energy values for all amino acids were compared for the native protein and mutants. It can be concluded that the first mutation stabilizes the heteroduplex in the protein, the rest destabilize, and the greatest effect is achieved for F164A. Kinetic studies have shown that there are no significant changes in the observed constants for the wild-type and mutant proteins when the substrate without mismatches was cleaved. For all mismatches, there was a decrease in wild-type cleavage activity. Specificity profiles of K163A and F164A mutants were slightly different between each other and between wild type protein. Interestingly, R403A mutant was more specific than the wild-type protein, but K918A was less specific.

Conclusion: We obtain a more specific Cas9 R403A mutant, and less specific Cas9 K918A mutant, but MD data not clearly correlate with kinetics. As a perspective we model heteroduplex with mismatch to find thermodynamics basics of Cas9 specificity.

\section{References}

1. Zuo Z, Liu J. Cas9-catalyzed DNA Cleavage Generates Staggered Ends: Evidence from Molecular Dynamics Simulations. Sci Rep. 2016;5:37584. 


\title{
Search for a new type of spatial organization of nucleic acids in human genome
}

\author{
Zamoskovtseva A.A. ${ }^{1,2 *}$, Lomzov A.A. ${ }^{1,2}$, Kabilov M.R. ${ }^{1}$, Pyshnyi D.V. ${ }^{1}$ \\ ${ }^{1}$ Institute of Chemical Biology and Fundamental Medicine SB RAS, Novosibirsk, Russia \\ ${ }^{2}$ Novosibirsk State University, Novosibirsk, Russia \\ *e-mail: zamosk_n@mail.ru
}

Key words: nucleic acids, pseudoknots, bioinformatic algorithm, human genome

Motivation and Aim: One of the functions of nucleic acids is regulation of various biological processes. In many ways, it is determined by the secondary and tertiary structures. Recently, a new type of spatial organization of nucleic acids was discovered in the ICBFM SB RAS. This self-limited complex contains two duplex fragments and single-stranded loops between them. It is called a TW-type pseudoknot (twiplex). It can be formed by single or two DNA (or RNA) chain, or in DNA/RNA intermolecular complex. The aim of the work is to determine the possibility of implementing TW-type pseudoknots with DNA chains of living systems.

Methods and Algorithms: To do this we searched for such sequences in the human genome using the home made Python scripts and proceed analysis using by RNAstructure program [1] to select sequences for further analysis. To verify experimentally the formation of TW-type pseudoknots by selected sequences we used a number of experimental methods such as thermal denaturation with optical signal registration, gel shift assay and the atomic force microscopy. Biological role analysis of such structures in the human genome was analyzed with the help of BLAST [2] and BEDTools [3].

Results: We suggested conditions required for twiplex formation such as oligonucleotide length limitation. Given the formulated conditions, an algorithm was developed for bioinformatic search on sequences which potentially can form twiplex, and on its basis a script in Python was written and applied for the human genome analysis. Structures with double-stranded blocks of the length from 5 to 20 base pairs are considered. Genome regions potentially capable for the twiplexes formation have been detected. The most represented structure which occurs more than 200 times in our sample and which is evenly distributed across all chromosomes, was chosen for further experimental analysis. The formation a TW-type pseudoknots by single DNA strand was confirmed using a model system by a gel-shift assay method. The location of the founded sequences in genes, introns or exons was analyzed. Experimental studies have begun to define the physicochemical and molecular biological properties of selected nucleotide sequences.

Acknowledgements: Supported by the RFBR (20-04-00719) and by State project no. A-0309-2016-0004.

\section{References}

1. Reuter JS, Mathews DH. RNAstructure: software for RNA secondary structure prediction and analysis. $B M C$ Bioinformatics. 2010;11:129. Published 2010 Mar 15.

2. Altschul SF, Gish W, Miller W, Myers EW, Lipman DJ. Basic local alignment search tool. J Mol Biol. 1990;215(3):403410. doi:10.1016/S0022-2836(05)80360-2.

3. Aaron R. Quinlan, Ira M. Hall, BEDTools: a flexible suite of utilities for comparing genomic features, Bioinformatics, V. 26, Issue 6, 15 March 2010, P.841-842. 
DOI 10.18699/SBB-2020-41

\title{
In vitro evaluation of new nuclease class II type V system
}

\author{
Zheltova A.*, Medvedev D., Polushkina I., Vasiliev R. \\ National Research Centre "Kurchatov Institute", Moscow, Russia \\ *e-mail: annettezv@gmail.com
}

Key words: CRISPR-Cas, nucleases, Cas12, Cpf1

Motivation and Aim: Adaptive immunity systems of prokaryotes CRISPR-Cas consist of Clustered Regularly Interspaced Short Palindromic Repeats (CRISPR) and CRISPR-associated proteins (Cas). CRISPR systems have been grouped into six different types (I-VI), which are divided into two large classes (I and II) [1]. One of the most widely used V type proteins is the Cpf1 (Cas12a). It has been shown that genome editing with CRISPR-Cas is a useful tool for genetic engineering. For example, Cpf1 orthologs such as Acidaminococcus sp. Cpfl (AsCpf1) show stable activity in mammalian cells and have been used to edit the genome of eukaryotic mammalian cells [2]. Nevertheless, there is an ongoing need for the search and development of new nucleases with improved definition of sequence-specific nucleic acid, its cleavage, and the ability to manipulate in various experimental conditions. The objective of this study was to carry out an in vitro evaluation of a new nuclease class II type $\mathrm{V}$.

Methods and Algorithms: Bioinformatic search made it possible to find and evaluate protein for in vitro testing. The nuclease sequence was obtained from the metagenome samples using PCR, and then cloning into a plasmid was carried out. The recombinant protein was obtained and purified using a Ni-NTA metal chelate column and cation exchange chromatography. To determine the activity of nuclease, experiments of in vitro cleavage under various conditions were performed; to assess the success of cleavage, electrophoresis was used.

Results: By bioinformatic search in metagenomic data, new effector Cas proteins were discovered. Bioinformatic evaluation was performed and the optimal protein for in vitro validation was selected. It was shown that this nuclease is an effector enzyme of the class II subtype V-A CRISPR-Cas. In addition, this nuclease is smaller than AsCpf. To determine the functional activity of new nuclease, various cleavage buffers were analyzed and the optimal one was selected (the experiment was carried out at 37 degrees for 30 minutes). Next, the time required for DNA cleavage was determined: there was no difference between 5 and 60 minutes. It was found some difference between efficiency of cleavage using full and split gRNA $(20+20)$. Also, with an increase in the concentration of protein and RNA, a dose-dependent cleavage of the DNA substrate was established. It was tested whether the cleavage of DNA by nuclease is temperature dependent. Incubation of nuclease, gRNA, and DNA template, carrying a protospacer flanked by the PAM sequence, at various temperatures resulted in efficient cleavage of the target in the temperature range 8-80 ${ }^{\circ} \mathrm{C}$ with maximum cleavage at 40 and $50{ }^{\circ} \mathrm{C}$.

Conclusion: A new active RNA-guided nuclease that efficiently introduces double-stranded breaks in target DNA was discovered and characterized.

\section{References}

1. Makarova K.S., Wolf Y.I., Iranzo J. et al. Evolutionary classification of CRISPR-Cas systems: a burst of class 2 and derived variants. Nat Rev Microbiol. 18, 67-83 (2020).

2. Zetsche B., Gootenberg J.S., Abudayyeh O.O. et al. Cpf1 is a single RNA-guided endonuclease of a class 2 CRISPRCas system. Cell. 2015;163(3):759-771. 


\title{
К вопросу о полногеномном секвенировании иммунного к грибным заболеваниям вида Vitis Rotundifolia Michaux
}

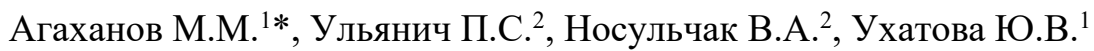 \\ ${ }^{1}$ Федеральный исследовательский иентр Всероссийский институт генетических ресурсов растений им. Н.И. Вавилова \\ (ВИР), Санкт-Петербург, Россия \\ ${ }^{2}$ Санкт-Петербургский государственный лесотехнический университет им. С.М. Кирова (СПбГЛТУ), \\ Санкт-Петербург, Россия \\ *e-mail: g.agakhanov@gmail.com
}

Ключевые слова: виноград, мускадиния, полногеномная сборка, донор устойчивости, полногеномное секвенирование, геномная сборка

Одним из уникальных источников генов устойчивости к оидиум и милдью для селекции винограда является североамериканский вид Vitis rotundifolia Michaux, относящийся к подроду Muscadinia. Этот вид можно считать практически иммунным к возбудителям оидиум и милдью, однако использовать этот ценный источник генов устойчивости для селекции европейских сортов винограда затруднительно.

Если виды подрода Euvitis легко скрещиваются между собой, то получить гибриды между V. vinifera (подрод Euvitis, 38 хромосом) и V. rotundifolia (подрод Muscadinia, 40 хромосом) ранее удавалось с большим трудом, при этом гибридные сеянцы становились фертильными только после их полиплоидизации. Очевидно, что ни созданный ранее селекционный гибридный материал с участием $V$. rotundifolia, ни материал, полученный вновь с целью поиска генов устойчивости к оидиуму, милдью и филлоксере, не удастся использовать целенаправленно без информации о геноме донора генов устойчивости - иммунного вида V. rotundifolia.

Нами было произведено два запуска на секвенаторе MinION (Oxford Nanopore Technologies) c использованием двух проточных ячеек типа R9.4.1. Перед запуском проводили диагностику ячеек с целью контроля их качества. По результатам диагностики на момент запуска на первой проточной ячейки FLO-MIN106D оказалось 1113 работоспособных белковых пор, - на второй - 1147.

Для ячейки № 2 ожидаемая длина фрагментов ДНК при приготовлении библиотеки составляла 20000 п.н. По результатам запуска, наибольшее число прочтений имело длину порядка 10000 п.н. В результате запуска двух проточных ячеек было прочитано 11 Гб (млрд пар оснований ДНК). Приблизительный размер генома Vitis vinifera L. $(2 n=38)$ составляет 435 Мб (млн оснований ДНК). Таким образом, возможное покрытие генома исследуемого вида V. rotundifolia, полученное в результате проведенного секвенирования, является приблизительно приблизительно двадцатикратным. Полученные данные позволяют перейти к следующему этапу исследований биоинформатическому анализу полученных данных секвенирования и полногеномной сборке.

Благодарности: Исследование выполнено при финансовой поддержке РФФИ в рамках научного проекта № 19-316-90007. 
DOI 10.18699/SBB-2020-43

\section{Кластеризация возрастных трендов экспрессии генов РВМС}

Алексеев А.А.

физический факультет МГУ имени М.В. Ломоносова, Москва, Россия

e-mail: alekseev@physics.msu.ru

Ключевые слова: старение, mRNA, тренды, скользящее среднее, кластеризация, РBMC

Введение: В настоящее время существует множество теорий старения человека, при этом для проверки этих теорий и построения системно-биологических моделей старения человека не хватает исходных данных в виде трендов, то есть изменения средних по популяции значений в омиксных данных [1]. В ряде недавних работ получены тренды по концентрации белков [2] и метаболитов [3] в крови, однако в настоящее время не развиты подходы для получения трендов экспрессии генов для клеток человека. Эта задача осложнена отсутствием в открытых источниках значимого объема данных экспрессии мРНК по различным тканям человека, а также межиндивидуальной и межполовой вариабельностью в этих данных. Как мы ожидаем, получение трендов экспрессии позволит сразу приобрести значительный материал для изучения изменений в сигнальных и метаболических путях при старении человека. Эта надежда подтолкнула нас к разработке подхода, позволяющего получить тренды экспрессии для РВМС человека по нескольким датасетам, а также метод кластеризации этих трендов.

Meтоды и результаты: Мы воспользовались открытыми данными из базы GEO: 4 датасета для PBMC человека GSE75511, GSE30483, GSE47353, GSE68759 и опорный датасет GSE65907. Изучены гены, которые пересекаются по всем датасетам (11145 генов). Для образцов в каждом датасете указан пол и возраст. Подгонка к распределению экспрессии генов опорного датасета осуществлялась по 10 и 90\% квантилям, функция оптимизации optim языка R, оптимизировались пары параметров линейной функции преобразования. В результате для каждого гена получены несколько «объединенных» наборов точек (отдельно по каждому полу). Далее, по разработанному нами алгоритму скользящего среднего для каждого гена была была получена серия трендов, после усреднения которых найден итоговый тред. Полученные тренды были скластеризованы по группам с помощью корреляции и последующего выделения кластеров в графе (с помощью функций библиотеки iGraph в R).

Bblвод: Разработан метод получения возрастных трендов экспрессии генов, и кластеров трендов для PBMC человека, в том числе для генов, связанных с NAD+ и NADPH, которые интересны в контексте изучения старения.

\section{Список литературы}

3. Ahadi S. et al. Personal aging markers and ageotypes revealed by deep longitudinal profiling. Nat Med. 26, 83-90 (2020). https://doi.org/10.1038/s41591-019-0719-5.

4. Lehallier B. et al. Undulating changes in human plasma proteome profiles across the lifespan. Nat Med. 25, 1843-1850 (2019). https://doi.org/10.1038/s41591-019-0673-2.

5. Bunning BJ et al. Global metabolic profiling to model biological processes of aging in twins. Aging Cell. 19, e13073 (2020). https://doi.org/10.1111/acel.13073. 


\section{Междисциплинарное исследование растительных остатков в древнерусском кладе}

Бабиченко Н.П.*, Пожидаев В.М., Яцишина Е.Б.

Национальный исследовательский иентр «Курчатовский Институт», Москва, Россия

*e-mail: babichenko28@gmail.com

Ключевые слова: ладан, газовая хроматография, босвеллиевые кислоты, масс-спектрометрия

Мотивация и цель: Изучение древних реликвий с использованием современных естественнонаучных методов значительно расширяет возможности получения уникальной информации, в том числе, в области христианской археологии и позволяет разработать надежные подходы к идентификации их содержимого. В рамках работы по изучению средневековых христианских древностей Суздальского Ополья (Владимирская область), рабочей группой НИЦ «Курчатовский институт» было проведено исследование археологического образца ладана из фондов ВладимироСуздальского музея.

Meтоды и алгоритмы: Методом ГХ/МС в испытуемом образце обнаружены соединения, которые входят в состав современных образцов ладана: 3 -эпи-лупеол, $\beta$-амиренон, $\alpha$ - и $\beta$-амирины, но отсутствовали основные биомаркеры - босвеллиевые кислоты и их ацетилированные производные. Кроме этого, в образце музейного ладана обнаружены 24-норолеан-3,12-диен, 24-норурса-3,12-диен и 4-норлупа-3,20(29)-диен. Эти компоненты являются известными продуктами термического разложения ладана [1-4]. Для исследования наличия пчелиного воска, остатки исследуемого образца после растворения в метаноле подвергали экстракции гексаном. Полученный экстракт анализировали методом ГХ/МС.

Результаты: По результатам проведенного исследования сделан вывод, что музейный образец представляет собой смесь остатков ладана из кадильницы после церковного богослужения и пчелиного воска.

Заключение и доступность: Археологический контекст находки позволяет высказать гипотезу о возможном отношении ее хозяина к изготовлению «воскомастики» из остатков ладана и воска для фиксации вложений-реликвий и створок крестов-энколпионов.

Благодарности: Авторы выражают благодарность главному хранителю ФГБУК «Государственный Владимиро-Суздальский историко-архитектурный и художественный музей-заповедник» Курниковой И. В. за предоставленный для исследований музейный образец.

Список литературы

6. Michael P. et al. A Thin-layer Chromatography Method for the Identification of Three Different Olibanum Resins (Boswellia serrata, Boswellia papyrifera and Boswellia carterii, respectively, Boswellia sacra). Phytochemical Analysis. 2012;23(2):184-189.

7. Mathe C.et al. Characterization of archaeological frankincense by gas chromatography-mass spectrometry. Journal Chromatography. 2004;1023(2):277-285.

8. Evershed R.P., et al. Archaeological frankincense. Nature. 1997;390(6661):667-668.

9. van Bergen P.F. et al. Chemical evidence for archaeological frankincense: Boswellic acids and their derivatives in solvent soluble and insoluble fractions of resin-like materials. Tetrahedron Letters. 1997;38(48):8409-8412. 
DOI 10.18699/SBB-2020-45

\section{Филогенетическое разнообразие культур аноксигенных фототрофных бактерий из водоемов России}

Бахмутова Е.*, Намсараев 3., Комова А.

НИЦ «Курчатовский институт», Москва, Россия

*e-mail: bahmutovaelizaveta@gmail.com

Ключевые слова: аноксигенные фототрофные бактерии, филогенетическое разнообразие

Мотивация и иель: Водоемы России обладают широким диапазоном физико-химических условий, и вследствие этого обитающие в них микробные сообщества характеризуются большим разнообразием. Цель данной работы - изучение филогенетического разнообразия культур аноксигенных фототрофных бактерий (АФБ), выделенных из водоемов России. АФБ могут быть использованы в биоремедиации, а также представляют интерес как потенциальные продуценты биополимеров, водорода и других промышленно важных веществ, поэтому эта работа очень актуальна.

Meтоды и алгоритмы: Объектами нашего исследования являются 20 культур АФБ, выделенных нашей научной группой из отобранных проб из 10 водоемов России. Из исследуемых культур АФБ была выделена ДНК, после чего 13 из полученных образцов использовались для проведения ПЦР на ген, кодирующий последовательность $16 \mathrm{~S}$ рРНК, с последующим секвенированием по Сэнгеру. Для остальных 7 образцов было проведено полногеномное секвенирование на приборе Illumina MiSeq. Последовательности генов $16 \mathrm{~S}$ рРНК исследуемых штаммов были выровнены против базы референсных последовательностей NCBI при помощи NCBI BLASTn. Было проведено множественное выравнивание с последовательностями отобранных ближайших родственных видов для каждого штамма, по результатам которого были построены филогенетические деревья.

Результаты: Согласно филогенетическому анализу, 15 из отобранных штаммов можно отнести к классу Alphaproteobacteria, 2 штамма относятся к классу Betaproteobacteria, 3 штамма относятся к классу Gammaproteobacteria. Были обнаружены штаммы, уровень сходства по последовательности $16 \mathrm{~S}$ рРНК и морфофизиологические характеристика которых позволяют отнести их к 2 новым родам и 4 новым видам в класcе Alphaproteobacteria. Были обнаружены штаммы, способные к аноксигенному фотосинтезу, в то время, как их ближайшие родственные виды являются хемотрофами.

Заключение и доступность: Был проведен филогенетический анализ 20 штаммов аноксигенных фототрофных бактерий, выделенных из проб воды из 10 водоемов России. Среди них были обнаружены потенциальные представители 2 новых родов и 4 новых видов.

Благодарности: Работа выполняется на основании Соглашения с Минобрнауки РФ № 075-15-20191659 от 31.10.2019. 


\title{
Скорость и качество решений лингвистических заданий с эмоциональными предложениями как возможный поведенческий маркер, отражающий адаптацию человека к приполярному климату
}

\author{
Белоногов А. ${ }^{1 *}$, Выскребцов А. ${ }^{1}$, Таможников С. ${ }^{2}$, Борисова Н. ${ }^{3}$, Афанасьева Е. ${ }^{3}$, Никонов H. $^{4}$, \\ Чикачева C. ${ }^{4}$, Савостьянов A. ${ }^{1,2,5}$ \\ ${ }^{1}$ Новосибирский государственный университет, ЛБМСПЧ ГИ, Новосибирск, Россия \\ ${ }^{2}$ НИИ физиологии и фундаментальной медицины, Новосибирск, Россия \\ ${ }^{3}$ Северо-Восточный Федеральный Университет им. М.К. Аммосова, Якутск, Россия \\ 4 Якутский Медииинский колледж, пос. Хандыга, Республика Саха, Россия \\ ${ }^{5}$ Институт циитологии и генетики СО РАН, Новосибирск, Россия \\ *e-mail: a.belonogov@g.nsu.ru
}

Ключевые слова: климатическая адаптация, моторный контроль, ERP, стоп-сигнал парадигма

Мотивация и цеель: Адаптация к условиям экстремального климата сопровождается повышенным риском развития аффективной патологии, включая тревожное расстройство и депрессию. Одной из когнитивных способностей, имеющих критически важное значение для успешности адаптации, является возможность распознавать эмоциональное состояние других людей. Целью данного исследования было изучение поведенческих показателей в условиях распознавания эмоциональной речи, отражающих состояние мигрантов при долговременной адаптации.

Meтоды и алгоритмы: В обследовании приняло участие 50 молодых, здоровых жителей поселка Хандыга (арктический район Якутии) и 50 здоровых мигрантов, приехавших в Якутию на длительный срок из южных регионов (Средняя Азия, Африка). Мигранты обследованы дважды сразу же после приезда в Якутию и через полгода после переезда. В эксперименте испытуемые выполняли задания по распознаванию грамматической структуры письменных предложений, выражавших разные эмоциональные состояния человека. Экспериментальные результаты сопоставлялись с поведенческими опросниками, которые тестировали риск развития аффективной патологии и личностные особенности людей.

Результаты: Выявлено, что низкий риск развития депрессии у мигрантов связан с высоким уровнем показателей индивидуализма и низкой привязанностью к оставленной дома семье. В поведенческом эксперименте повышенный уровень стресса при адаптации вызывал снижение скорости и качества решения экспериментальных заданий с предложениями, описывающими ситуации агрессии.

Заключение: Анализ поведенческих реакций в условиях распознавания эмоциональной речи позволяет оценить общий уровень стресса и предрасположенность к аффективным нарушениям у людей, в момент адаптации к новым условиям жизни.

Благодарности: Поддержано грантом РФФИ № 18-415-140021 и № 18-29-13027. Исследование А.Н. Савостьянова проводятся в рамках бюджетного проекта ИЦиГ СО РАН № 0324-2019-0040-С-01. 
DOI 10.18699/SBB-2020-47

\title{
Молекулярный скрининг образцов кабачка и патиссона (Cucurbita pepo L.) \\ из коллекции ВИР и оригинального селекционного материала Крымской ОСС ВИР на наличие маркеров устойчивости к мучнистой росе
}

\author{
Беренсен Ф.А. ${ }^{1 *}$, Москалу А.Ф. ${ }^{1,2}$, Антонова О.Ю. ${ }^{1}$, Кузьмин С.В. ${ }^{2}$, Пискунова Т.М. ${ }^{1}$ \\ ${ }^{1}$ Институт генетических ресурсов растений им. Н.И. Вавилова (ВИР), Санкт-Петербург, Россия \\ ${ }^{2}$ Крымская опытно-селекционная станция - филиал ВИР, Крымск, Россия \\ *e-mail:fberensen@gmail.com
}

Ключевые слова: Cucurbita pepo L., кабачок, BИР, устойчивость, мучнистая роса, MAS, Pm-O

Мотивация и цель. Мучнистая роса (возбудители - гриб Eryzihhe cichotacearum (DC.) и гриб Sphaerotheca fuliginea Poll.) является одним из самых распространенных заболеваний у растений Cucurbita pepo L. на территории РФ. Устойчивость сортов к данному заболеванию может быть обеспечена за счет $R$-генов, в частности, гена $P m-O$, интрогрессированного от дикого вида $C$. okeechobeensis subsp. martinezii. Для данного гена разработаны CAPS маркеры NBS_S9_1495924/HaeIII и S9_1539675/MspI [1], которые были предложены для использования в маркер-вспомогательной селекции (MAS). Цель исследования провести скрининг образцов C. реро для выявления маркеров гена $P m-0$.

Материалы и методы: Были отобраны 72 образца и селекционных линий кабачка и патиссона из коллекций ВИР и Крымской опытно-селекционной станции ВИР (КОСС) с оцененной полевой устойчивостью к мучнистой росе. Амплификацию с последующей рестрикцией проводили по протоколу авторов маркеров [1].

Результаты: Образцы КОСС, оцененные как устойчивые, в 53,8\% проявляли наличие доминантного аллеля гена $\mathrm{Pm}-0$ по результатам скрининга обоими маркерами, в $37,7 \%$ на это указывал хотя бы один маркер. В то же время среди 27 устойчивых к мучнистой росе образцов коллекции ВИР диагностические фрагменты обоих маркеров имели только образцы к-5520 и к-5522, что позволяет предположить наличие других генов резистентности, например, $P m-1$. В то же время у 9,7\% образцов с оценкой «восприимчивые» также были детектированы маркеры гена Pm-0. При анализе индивидуальных растений для ряда образцов было показано наличие гетерогенности.

Заключение. Апробированные маркеры проявляют достаточную, хотя и не абсолютную, ассоциацию с полевой устойчивостью и могут быть использованы в молекулярном скрининге образцов кабачка и патиссона для выявления потенциально устойчивых к мучнистой росе форм.

Благодарности. Работа выполнена в рамках государственного задания № 0481-2019-0002.

Список литературы

1. Holdsworth W.L. et al. PLOS ONE. 2016;11(12): e0167715. DOI: 10.1371/journal.pone.0167715. 


\section{Изучение распространения и генетического разнообразия Phaeomoniella chlamydospora и Phaeoacremonium aleophilum на территории виноградных насаждений Краснодарского края и Крыма}

Блинова С.А. ${ }^{1,2 *}$, Шварцев А.А. ${ }^{1}$, Странишевская Е.П. ${ }^{3}$, Володин В.А. ${ }^{3}$, Ильницкая Е.Т. ${ }^{4}$, Макаркина М.В. ${ }^{4}$, Алексеев Я.И. ${ }^{1,3}$

${ }^{1}$ ООО «Синтол», Москва, Россия

2 ФГБНУ ВНИИСБ, Москва, Россия

${ }^{3}$ ВННИИВиВ «Магарач» РАН, Ялта, Республика Крым

${ }^{4}$ ФГБНУ СКФНЦСВВ, Краснодар, Россия

*e-mail: Sofya.blinova@yandex.ru

Ключевые слова: ПЦР, генотипирование, скрининг, эска, болезнь Петри

Мотивация и иель: Болезни Петри и эска являются сдерживающим фактором для производства винограда по всему миру (Chiarappa, 2000). К настоящему времени на территории России не проводилось скрининговых исследований распространения возбудителей болезней Петри и эска с использованием молекулярно-генетических методов. В нашем исследовании был проведен скрининг Phaeomoniella chlamydospora и Phaeoacremonium aleophilum на территории виноградников Краснодарского края и южного берега полуострова Крым, изучена их локализация в лозе винограда, а также проведено генетическое типирование выявленных изолятов Phaeoacremonium aleophilum.

Meтоды и алгоритмы: Количество образцов винограда для исследования составило 190 шт. Для определения локализации патогенов в растительном материале было проведено выделение НК из трех частей одной лозы. Статистическая обработка данных проводилась в приложении RStudio ver. 8.12.175.481. Скрининг образцов винограда на наличие целевых грибов проводили методом ПЦР с последующей визуализацией продуктов амплификации на приборе НАНОФОР 05.

Результаты: Использованная в работе система праймеров позволяет проводить эффективное выявление Phaeoacremonium aleophilum и Phaeomoniella chlamydospora в том числе и на бессимптомных лозах.

В ходе исследования установлены места локализации целевых грибов, которые со статистической значимостью преимущественно концентрируются в проводящей системе растений. Результаты нашего исследования позволяют рекомендовать использование в качестве образца для выделения проводящую систему винограда для выявления Phaeoacremonium aleophilum и Phaeomoniella chlamydospora.

При генотипировании выявленных образцов Phaeoacremonium aleophilum не выявлено ни одного изолята повторяющего полностью все нуклеотидные замены выложенных в базе GeneBank штаммов.

Список литературы

1. Chiarappa, L. (2000): Esca (black measles) of grapevine. An overview. Phytopathol Mediterranea. 2000;39(1):11-15. 
DOI 10.18699/SBB-2020-49

\section{Эффект использования полных митохондриальных геномов и их отдельных фрагментов для делимитации видов}

Болбат А.В. ${ }^{1 *}$, Болбат Н.Б. ${ }^{1}$, Васильев Г.В. ${ }^{2,}$ Богданова В.С. ${ }^{2}$, Матвеенко Е.Ю. ${ }^{1}$, Кайгородова И.А. ${ }^{1}$

${ }^{1}$ Лимнологический институт СО РАН, Иркутск, Россия

${ }^{2}$ Институт цитологии и генетики СО РАН, Новосибирск, Россия

*e-mail: bolbatav@lin.irk.ru

Ключевые слова: митохондриальный геном, cox1, 12S, делимитация видов

Мотивация и цель: Сегодня для идентификации биологических видов приобретают популярность молекулярно-генетические методы. Цель данной работы - изучить влияние длины генетической последовательности на эффективность методов молекулярной делимитации таксонов.

Meтоды и алгоритмы: 50 полных митохондриальных последовательностей кольчатых червей были выровнены последовательным использованием MARS и Muscle. Фрагменты универсальных маркерных последовательностей coxl (700 н.п.) и 12S pРНК (430 н.п.) были выбраны из этого массива. Филогения реконструирована BEAST2 с параметрами, рекомендованными jModelTest2. Для детекции оперативных таксономических единиц (ОTЕ) использован GMYC.

Результаты: Древо на основе полных митогеномов показало наибольшее совпадение порядка ветвления с современной классификацией. coxl-филогения демонстрирует некоторые отличия на уровне отрядов, сохранив корректной кластеризацию подклассов. При реконструкции филогении по гену $12 \mathrm{~S}$ кластеризация была нарушена вплоть до уровня классов. Алгоритм GMYC выявил прямую зависимость числа ОТЕ от длины последовательности: 17, 41 и 49 для 12S, coxl и полного митогенома соответственно.

Заключение: Использование полных митогеномов для делимитации видов приводит к избыточному дроблению ОТЕ, тогда как использование коротких и вариабельных нуклеотидных фрагментов ведет к чрезмерной группировке. Общепринятый для использования в ДНК-штрихкодировании фрагмент coxl продемонстрировал наилучшие результаты для разделения видов. Наиболее точные результаты реконструкции филогении были получены на основе полных геномов.

Благодарности: Работа была профинансирована за счет грантов РФФИ № 17-29-05097, 19-34-50072 и 19-34-90011. Секвенирование образцов проводилось в Центре Геномных Исследований ИЦиГ СО РАН. Сборка части митогеномов проводилась на серверах Сибирского суперкомпьютерного центра CO PAH. 


\section{Исследование коэволюционных процессов в системе паразит-хозяин на примере видов рода Mycobacterium sp.}

Бондаренко Т.А.*, Бородулин А.В., Борунова В.В., Луданный Р.И.

Центральный исследовательский институт эпидемиологии Роспотребнадзора, Москва, Россия

*e-mail: nikkybondarenko@yandex.ru

Key words: туберкулез, геномика, коэволюция

Мотивация и иель: В процессе коэволюции, путем адаптивных генетических перестроек, происходила специализированная адаптация микобактерий в системе паразит-хозяин, обеспечивая селективное преимущество патогенным видам. В связи с этим, целью нашего исследования является сравнительный молекулярно-генетический анализ полногеномных нуклеотидных последовательностей патогенных и условно-патогенных видов микобактерий, позволяя выявить генетическую значимость определенных генов, играющих ключевую роль в коэволюционных процессах.

Meтоды $и$ алгоритмы: Для сравнительного анализа нами были отобраны пять основных представителей туберкулезных (M. tuberculosis, M. avium, M. bovis) и нетуберкулезных (M. kansasi, M. smegmatis) видов микобактерий, полногеномные последовательности которых, ранее были депонированы в базе данных NCBI и использованы нами в последующем биоинформатическом анализе. Для определения GC-состава, расчетов индексов нуклеотидной парной идентичности и генетических дистанций использовалась программа GENEIOUS (ver. 7.0.9.). В связи с тем что не все геномы были аннотированы, нами была проделана автоматическая аннотация некоторых последовательностей с использованием программы Blast2GO (ver. 5.1). В связи с низким индексом идентичности геномов было принято решение рассчитать время дивергенции с помощью пакета программ MEGA(ver. 10.0.5), сопоставив его с временем дивергенции хозяина.

Результаты: Сравнительный анализ показал, что размер генома уменьшался в направлении от: не туберкулезных (M. smegmatis - 6,9 kb; M. kansasi - 6,5kb; M. avium-5kb) к туберкулезным видам (M. tuberculosis - 4,5 kb; M. bovis - 4,3 kb). Было обнаружено, что показатель генетической идентичности между анализируемыми видами варьировал от 1,4 до $8,3 \%$, в зависимости от выбора референтной последовательности. В связи с этим, для последующего анализа были использованы только кодирующие участки генома микобактерий. Было показано, что уровень идентичности в этих участках варьирует в пределах 81.7-90.7\% при покрытии 22-43\%. Эти данные не смогли ответить на вопрос, какие участки ответственны за патогенные свойства микобактерий. Данная работа предполагает в дальнейшем поиск ортологичных генов, которые могли быть утрачены в процессе приобретения микобактериямии патогенных свойств. 


\title{
Исследование повторяющихся последовательностей генома образцов конопли посевной (Cannabis sativa L.)
}

\author{
Бочаркина Ю.В. ${ }^{1,2 *}$, Разумова О.В. ${ }^{1}$, Карлов Г.И. ${ }^{1}$ \\ ${ }^{1}$ Лаборатория прикладной геномики и частной селекции сельскохозяйственных растений, Всероссийский научно- \\ исследовательский институт сельскохозяйственной биотехнологии, Россия \\ ${ }^{2}$ Сколковский Институт Науки и Технологий, Россия \\ *julia.bocharkina@skoltech.ru
}

Ключевые слова: репитом, конопля посевная, NGS

Мотивация и цель: Размеры растительного генома велики, а повторяющиеся последовательности один из основных его компонентов. Они разнородны, могут различаться по уровню копийности, функции их не до конца изучены. Однако известно, что ДНК-повторности играют важную роль в стабилизации и организации структур генома, также они вовлечены в процесс деления клеток и участвуют в регуляции экспрессии некоторых генов [1]. Поэтому изучение репитомов различных представителей живого мира является важной биоинформатической задачей.

Meтoдbl: ДНК растений Cannabis sativa L. была выделена из листьев в соответствии с протоколом [2]. Секвенирование проведено с помощью аппарата Illumina MiSeq, библиотеки подготовлены согласно коммерческим инструкциям. Биоинформатический анализ рептомов проводился на локальном сервере с 28 ядерными процессорами и 128 ГБ ОЗУ, работающим под управлением операционной системы Linux с использованием RepeatExplorer [3]. Кластеры, содержащие не менее $0,01 \%$ всех кластерных чтений, были охарактеризованы с помощью RepeatMasker [4] c использованием базы данных Repbase [5].

Pезультаты: В данной работе мы провели анализ репитомов женского и мужского растения Cannabis sativa L. Более половины ридов оказались в топ-кластерах. Большую часть репитома составили мобильные элементы 1-го класса, 24\% поделили между собой повторы из органелл и сателлитные, остальная часть - мобильные элементы 2-го класса, рибосомальная ДНК и группа неклассифицированных повторов.

Благодарности: Работа выполнена при финансовой поддержке РФФИ номер соглашения 20-316$70018 \backslash 19$.

Список литературы

1. Fedoroff N.V. Transposable elements, epigenetics, and genome evolution. Science. 2012;338(6108):758-767.

2. Doyle J.J. Isolation of plant DNA from fresh tissue. Focus. 1990;12:13-15.

3. Novák P. et al. RepeatExplorer: a Galaxy-based web server for genome-wide characterization of eukaryotic repetitive elements from next-generation sequence reads. Bioinformatics. 2013;29(6):792-793.

4. Smit A.F.A., Hubley R., Green P. RepeatMasker Open-4.0. 2013-2015. 2015.

5. Jurka J. et al. Repbase Update, a database of eukaryotic repetitive elements. Cytogenetic Genome Research. 2005;110(1-4):462-467. 


\section{Особенности выделения нуклеиновых кислот из эфиромасличных растений}

Браилко В.А.*, Булавин И.В., Гребенникова О.А., Митрофанова И.В.

Федеральное бюджетное учреждение науки «Ордена Трудового Красного Знамени Никитский ботанический сад -

Национальный научный центр РАН», Ялта, Россия

*e-mail: valentina.brailko@yandex.ru

Ключевые слова: эфиромасличные растения, ДНК, качество, спектрофотометрия, автоматический электрофорез

Цель: Для целей генотипирования и маркерной селекции эфиромасличных растений были подобраны и оптимизированы протоколы выделения ДНК, поскольку присутствие белков, полисахаридов и вторичных метаболитов, снижает эффективность ПЦР и качество библиотек для последующего секвенирования.

Oбъекты и методы: Работа выполнена на 10 сортах Rosa damascena Mill., 4 сортах Lavandula angustifolia Mill., 3 copтах Lavandula $\times$ intermedia Emeric. ex Loisel. и 4 сортах Thymus L. произрастающих в коллекции Никитского ботанического сада. Для выделения ДНК из молодых листьев использовали как коммерческие наборы, так и классический способ выделения (СТАВметод) и его модификации. Количество и качество ДНК определяли с помощью нанофотометра NanoPhotometer NP80 (Implen, Германия) и автоматической системы электрофореза Agilent 4200 TapeStation (Agilent Technologies, Германия).

Результаты: В тканях изученных растений включения с эфирными маслами (капли различного диаметра) находились в клетках мезофилла и железках, также обнаружены фенольные соединения. Качество всех образцов ДНК розы эфиромасличной, выделенных согласно протоколам коммерческих наборов было низким: $\mathrm{A}_{260 / 230}$ и $\mathrm{A}_{280 / 260}<1,30$, концентрация 52-146 нг/мкл. Для лаванды и лавандина количественный выход ДНК соответствовал указанным в протоколах значениям, соотношение $\mathrm{A}_{260 / 230}$ было $<1,80$. ДНК низкого качества получена с использованием автоматизированной системы подготовки проб (MagNA Pure LC 2.0, (Roche, Швейцария) с MagNA Pure Compact Nucleic Acid Isolation Kit I (Roche, Швейцария) и наборов DiamondDNA ${ }^{\mathrm{TM}}$ (DiamondDNA, Россия), PureLink ${ }^{\circledR}$ Plant Total DNA Purification Kit (Thermo Scientific ${ }^{\mathrm{TM}}$, СШA). Протоколы GeneJET Plant Genomic DNA Purification Kit (Thermo Scientific ${ }^{\mathrm{TM}}$, США) и NucleoSpin ${ }^{\circledR}$ Plant II Mini (Macherey-Nagel,Германия) позволили получить от 960 до 2800 нг ДНК из 100 мг ткани $\left(\mathrm{A}_{260 / 230}=1,65-1,80, \mathrm{~A}_{280 / 260}=1,03-1,96\right)$. Наилучшие результаты для всех исследованных растений получены при использовании СТАВ-метода и его модификаций (выход ДНК от 1,5 до 31,0 мг; $\mathrm{A}_{260 / 230,} \mathrm{~A}_{280 / 260}>1,9$; молекулярный размер от 42000 до >60 000 п.о.).

Bblвoдbl: Модифицирован и оптимизирован СТАВ-протокол выделения ДНК из ряда эфиромасличных растений, позволивший провести эффективную экстракцию ДНК из тканей исследуемых видов.

Благодарности: Работа выполнена в рамках Госзадания № 0829-2019-0038 ФГБУН «НБС-ННЦ» на базе УНУ «ФИТОБИОГЕН». 


\title{
Изучение генетической регуляции накопления кутикулярного воска ячменя при помощи анализа данных RNA-seq
}

\author{
Вихорев А. ${ }^{1,2 *}$, Шмаков Н. ${ }^{1}$, Колосовская Е. ${ }^{1,2}$, Короткова А. ${ }^{1}$, Герасимова С. ${ }^{1,2}$, Хлесткина Е. ${ }^{1,2,3}$ \\ ${ }^{1}$ Институт цитологии и генетики СО РАН, Новосибирск, Россия \\ ${ }^{2}$ Новосибирский государственный университет, Новосибирск, Россия \\ ${ }^{3}$ ФИЦ Всероссийский институт генетических ресурсов растений имени Н.И. Вавилова, Санкт-Петербург, Россия \\ *e-mail: vikhorev@bionet.nsc.ru
}

Ключевые слова: ячмень, Hordeum vulgare, эпикутикулярный воск, RNA-seq

Мотивация и цель: Наличие и строение эпикутикулярного воскового покрова является селекционно-важным признаком ячменя, связанным с защитой от внешних неблагоприятных факторов. Однако на данный момент генетика этого признака слабо изучена. Ранее была получена линия ячменя winl c нокаутированным геном HvWIN1. Для этой линии было показано отсутствие бета-дикетонов на поверхности листового влагалища. Цель данной работы - изучение генетической регуляции накопления эпикутикулярного воска ячменя при помощи анализа изменений в экспрессии генов мутантной линии win1 по гену HvWIN1.

Meтоды и алгоритмы: Была секвенирована РНК из листовых пластинок и листовых влагалищ двух линий $H$. vulgare: дикий тип и мутантная линия win1. Для каждого образца было взято по четыре биологических повторности. Оценка качества прочтений была произведена при помощи FASTQC, предобработка была произведена в программе Trimmomatic. Для картирования прочтений использовалась программа DART, квантификации осуществлялась при помощи функции featureCounts пакета Subread. Поиск дифференциально экспрессирующихся генов (ДЭГ) был произведен при помощи edgeR. Аннотация ДЭГов была осуществлена при помощи AgriGO и BlastKOALA.

Результаты: Всего было секвенировано 16 библиотек РНК, прошедшие предобработку библиотеки содержат 440 млн (94\%) прочтений. Успешно картировались на референсный геном в среднем $98,76 \%$ прочтений. После удаления генов со слишком низкой экспрессией было обнаружено, что 26807 из 39841 генов ячменя (67,3\%) имеют значимую экспрессию в исследуемых органах. Всего было обнаружено 808 генов с повышенной и 765 генов с пониженной экспрессией в листовой пластинке линии win1, а также 605 генов с повышенной и 81 ген с пониженной экспрессией в листовом влагалище линии win1 (при пороге $|\log \mathrm{FC}|>2$, FDR $<0.05$ ). Среди генов с повышенной экспрессией были обнаружены гены, связанные с синтезом жирных кислот и компонентов клеточной стенки. Среди генов с пониженной экспрессией были обнаружены гены, ассоциированные с синтезом компонентов эпикутикулярного воска.

Заключение: Были найдены и аннотированы гены, изменяющие экспрессию после нокаута гена HvWIN1. Полученные результаты позволят выявить конкретные гены, участвующие в синтезе эпикутикулярного воска у ячменя.

Благодарности: Работа выполнена при поддержке РНФ № 16-14-00086. 


\title{
Вызванные потенциалы головного мозга (ERPs) в условиях решения лингвистических задач как нейрофизиологический маркер адаптации к приполярному климату
}

\author{
Выскребцов А. ${ }^{1 *}$, Белоногов А. ${ }^{1}$, Таможников С. ${ }^{2}$, Сапрыгин А. ${ }^{2,4}$, Борисова Н. ${ }^{3}$, Карпова А. ${ }^{3}$, \\ Афанасьева Е. ${ }^{3}$, Савостьянов А. ${ }^{1,2,4}$ \\ ${ }^{1}$ Новосибирский государственный университет, ЛБМСПЧ ГИ, Новосибирск, Россия \\ ${ }^{2}$ НИИ физиологии и фундаментальной медицины, Новосибирск, Россия \\ ${ }^{3}$ Северо-Восточный Федеральный Университет им. М.К. Аммосова, Якутск, Россия \\ ${ }^{4}$ Институт изитологии и генетики СО РАН, Новосибирск, Россия \\ *e-mail: a.vyskrebtsov@g.nsu.ru
}

Ключевые слова: климатическая адаптация, личностная тревожность, ERP, распознавание речи

Мотивация и иеель: Распознавание эмоциональной окраски речи является одной из способностей человека, необходимой для регуляции социального поведения. Целью данного исследования было изучение динамики мозговой активности у трудовых мигрантов в ходе их адаптации к приполярным условиям, при помощи анализа мозговых вызванных потенциалов, регистрируемых при распознавании эмоциональной письменной речи.

Meтоды и алгоритмы: В обследовании приняло участие 50 молодых, здоровых жителей поселка Хандыга (арктический район Якутии) и 50 здоровых мигрантов, приехавших в Якутию на длительный срок из южных регионов (Средняя Азия, Африка). Мигранты обследованы дважды сразу же после приезда в Якутию и через полгода после переезда. В эксперименте с одновременной регистрацией ЭЭГ испытуемые выполняли задания по распознаванию грамматической структуры письменных предложений, выражавших разные эмоциональные состояния человека (страх, тревога и агрессия, отнесенные либо к самому участнику, либо к другим людям). Вызванные потенциалы (ERP) оценивались для предложений с разной эмоциональной окраской на разных временных интервалах и в разных областях коры. Были выполнены сопоставления коренного населения и мигрантов, и также сравнения внутри одной группы мигрантов на разных этапах адаптации.

Результаты: Различия между мигрантами и коренным населением были выявлены для амплитуды пиков N400, P300 и Р600. В ходе первого этапа адаптации мигранты показали повышенную активацию правого полушария в сравнении с коренным населением региона. В течение полугода адаптации у мигрантов наблюдается увеличение амплитуды для всех компонентов ERP, связанных с распознаванием речи, что можно рассматривать как результат лучшего усвоения языка.

Заключение: Анализ вызванных потенциалов головного мозга в условиях распознавания эмоциональной речи может быть использован для изучения нейрофизиологических процессов, связанных с социальной адаптацией к новым условиям жизни.

Благодарности: Поддержано грантами РФФИ № 18-415-140021 и № 18-29-13027. Исследование А.Н. Савостьянова и А.Е. Сапрыгина проводятся в рамках бюджетного проекта ИЦиГ СО РАН № 0324-2019-0040-C-01. 
DOI 10.18699/SBB-2020-55

\title{
Сравнение методов выделения высокомолекулярной ДНК из плодов растений для нанопорового секвенирования
}

\author{
Гладышева-Азгари М.В.*, Петрова К.О. \\ НИЦ «Курчатовский институт», Курчатовский иентр геномных исследований, Москва, Россия \\ *e-mail: marglader@gmail.com
}

Ключевые слова: выделение ДНК, плодовые культуры, СТАВ, GITC, Oxford Nanopore

Мотивация и цель: С возрастом органы растения накапливают метаболиты, которые соосаждаются с нуклеиновыми кислотами при экстракции, поэтому высокомолекулярную ДНК хорошего качества легче выделить из молодых свежесобранных образцов незапасающих тканей. Однако получение молодых листьев в качестве исходного материала иногда не представляется возможным. Протоколы выделения ДНК из тканей растений обычно видоспецифичны, адаптированы только для листьев или требуют большого количества исходного материала. Цель данной работы - выявление наиболее универсального метода получения высокомолекулярной растительной ДНК из зародышей плодовых культур.

Maтериальl и алгоритмы: Для получения ДНК были взяты плоды сортов персика («Красная Москва», «Ветеран»), инжира («Медовый»), яблони и винограда. Мы сравнили три различных протокола для экстракции растительной ДНК: CTAB-метод выделения ДНК, GITC-метод и метод выделения для нанопорового секвенирования. Оценка качества и количества выделенной ДНК произведена на спектрофотометре NanoDrop 1000 (Thermo Scientific) и флюориметре Qubit (Thermo Scientific). Молекулярный вес ДНК оценивался при помощи электрофореза в агарозном геле.

Результаты: При применении различных методов для экстракции ДНК из зародышей наших объектов мы получили низкие концентрации ДНК с высоким уровнем загрязненности другими органическими агентами, что может быть связано с избытком и разнообразием запасающих веществ в этих тканях. В некоторых случаях благодаря нескольким стадиям очистки и переосаждений удалось избавиться от большей части загрязнителей.

Заключение: Мы протестировали несколько основных методов выделения высококачественной ДНК из плодов различных представителей плодовых культур. Было показано, что для экстракции ДНК из плодов необходима дополнительная модификация этих методов с целью удаления растительных метаболитов, связывающихся с нуклеиновыми кислотами.

Источник финансирования: Работа выполнена в Курчатовском центре геномных исследований при поддержке Министерства науки и высшего образования РФ, грант № 075-15-2019-1659. 


\title{
Хромосома линии половых клеток зебровой амадины: анализ повторяющихся последовательностей
}

\author{
Давидьян А. ${ }^{1 *}$, Володькина В. ${ }^{1}$, Комиссаров А. ${ }^{2}$, Галкина С. ${ }^{1}$ \\ ${ }^{1}$ Санкт-Петербургский государственный университет, Санкт-Петербург, Россия \\ ${ }^{2}$ Национальный исследовательский университет ИТМО, Санкт-Петербург, Россия \\ *e-mail: asya.davidian@gmail.com
}

Ключевые слова: Taeniopygia guttata, хромосомы типа ламповых щеток, ооцит

Мотивачия и иель: В гаметах зебровой амадины кроме обычных аутосом и половых хромосом ZW $(2 \mathrm{n}=80)$ обязательно присутствует хромосома линии половых клеток (germline-restricted chromosome, GRC) [1]. GRC отсутствует во всех соматических клетках, элиминируется при созревании сперматозоидов и, как следствие, передается только по женской линии. В состав GRC входит $>10 \%$ генома, т.е. $\sim 150$ млн.п.н. [2]. Детального представления о ее роли, поведении в мейозе и эмбриогенезе до сих пор нет. С целью изучения функционирования GRC в оогенезе мы идентифицировали эту хромосому на стадии ламповых щеток (ЛЩ) и выполнили детальный анализ гетерохроматиновых “поясков” - характерных конденсированных участков без боковых петель.

Meтоды и алгоритмы: Морфологическое описание GRC проводили с помощью FISH и иммуноцитохимии с антителами к коилину. Библиотеки для секвенирования из WGA амплифицированного микродиссектированного материала «поясков» готовили с помощью (1) NEBNext Ultra DNA Library Prep Prep и (2) Agencourt AMPure XP с насыщением длинными фрагментами. Секвенирование проводили на Illumina NextSEq 550 в режиме одностороннего прочтения. Сборку контигов осуществляли ассемблером Geneious с высокой чувствительностью (Geneious 9.0). Поиск гомологичных последовательностей в GenBank проводили с помощью BLAST, а известных повторов - используя RepBase (www.girinst.org/censor/).

Результаты: Мы показали, что «пояски» GRC на стадии ЛЩ всегда ассоциированы с внутриядерными коилин-позитивными тельцами. В состав «поясков» входят в основном эндогенные ретровирусы ERV1 и 2, а также ДНК транспозоны, утерявшие способность к транспозиции.

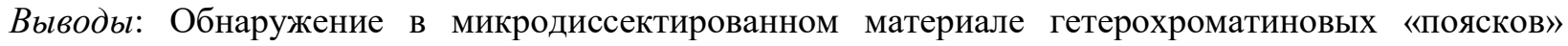
разнообразных рассеянных повторов можно считать парадоксом, так как известно, что на стадии ЛЩ идет активная транскрипция рассеянных повторов с петель [3]. Возможно, что гетерохроматиновая организация этих маркерных для GRC структур (более нигде не встречающихся на ЛЩ) связана с наличием специфических белков, подавляющих деконденсацию хроматина и образование транскрипционно активных петель на стадии ЛЩ.

Благодарности: проф. Н.Б. Рубцову (ИЦиГ СО РАН), РЦ «ЦКП Хромас» СПбГУ, РЦ «Геномика» ИЦиГ СО РАН, РФФИ 20-04-00967.

\section{Список литературы}

1. Pigozzi M.I., Solari A.J. Chrom. Res. 6, 105-113 (1998).

2. Torgasheva A. et al. PNAS. 116, 11845-11850 (2010).

3. Сайфитдинова А.Ф., Галкина С.А., Гагинская Е.Р. Генетика. (2020). В печати. 


\section{Разработка биосенсоров для количественной оценки уровня аминокислот in vivo}

Евтеева М.А.*, Васильев Р.А.

Научно-исследовательский ичентр «Курчатовский институт», Москва, Россия

*e-mail: evteevamarta@gmail.com

Ключевые слова: биосенсоры, регуляторные элементы, рибопереключатели, штаммы-продуценты

Мотивация и цель: Промышленно важные аминокислоты такие как лизин, валин, триптофан и треонин производят с помощью бактериального синтеза. Тем не менее скрининг штаммовпродуцентов этих аминокислот является трудоемкой и затратной задачей. В связи с чем целью данной работы явилось конструирование генетических сетей для внутриклеточного мониторинга концентрации аминокислот в бактериальных продуцентах для формирования технологии скрининга.

Meтоды $и$ алгоритмы: Определение внутриклеточных концентраций целевых аминокислот в штаммах-продуцентах основано на использовании генетических сетей с рибопереключателями Тбокс, которые являются природными внутриклеточными сенсорами статуса аминоацилирования тРНК: они способны формировать шпильки, терминирующие транскрипцию, либо блокирующие инициацию трансляции нижележащего гена при связывании с аминоацилированными тРНК [1-3]. Данное свойство Т-боксов легло в основу детектирующего модуля конструируемых сенсоров.

Pезультаты: Были получены «детектирующие плазмиды», способные отображать внутриклеточные уровни аминокислот за счет флуоресценции EGFP. В случае низких концентраций вносимых аминокислот не наблюдалось значительных различий в уровнях флуоресценции для Lлизина и L-валина. Для высоких концентраций аминокислот показана эффективность работы сенсора L-валина.

Заключение и доступность: Продемонстрирована принципиальная возможность создания сенсоров аминокислот на основе конструкций, содержащих рибопереключатели «Т- бокс». В дальнейшем планируется оптимизация работы данных сенсоров.

Благодарности: Работа выполнена при поддержке НИЦ «Курчатовский институт» (приказ № 1360 от «25» июня 2019 г.).

\section{Список литературы}

1. Kreuzer K.D., Henkin T.M. The T-Box Riboswitch: tRNA as an Effector to Modulate Gene Regulation. Microbiol Spectrum. 2018. Vol. 6, № 4.

2. Vitreschak A.G. et al. Comparative genomic analysis of T-box regulatory systems in bacteria. RNA. 2008. Vol. 14, № 4. p. $717-735$.

3. Grigg J.C., Ke A. Sequence, structure, and stacking: Specifics of tRNA anchoring to the T box riboswitch. RNA Biol. 2013. Vol. 10, № 12. p. 1761-1764 


\section{Направленный нокаут гена вакуолярной инвертазы Pain-1 в Solanum tuberosum L.}

Егорова А.А. ${ }^{1,2 *}$, Герасимова С.В. ${ }^{1,2}$, Коэппель И. ${ }^{3}$, Хамаз С. ${ }^{4}$, Хикель Ш. ${ }^{3}$, Хертиг К. ${ }^{3}$, Ибрагимова С.М. ${ }^{1}$, Сабоиев И.А. ${ }^{1}$, Нестеров М.А. ${ }^{1}$, Кумлен Й. ${ }^{3}$, Салина Е.А. ${ }^{1}$, Кочетов А.В. ${ }^{1,2}$

${ }^{1}$ Курчатовский геномный центр, Институт Цитологии и Генетики СоРАН, Новосибирск, Россия

${ }^{2}$ Новосибирский государственный университет, Новосибирск, Россия

${ }^{3}$ IPK, Gatersleben, Germany

${ }^{4}$ Erfurt Research Centre for Horticultural Crops, Erfurt, Germany

*e-mail: egorova@bionet.nsc.ru

Ключевые слова: картофель, генное редактирование, вакуолярная инвертаза

Картофель (Solanum tuberosum L.) является одной из самых важных мировых овощных культур. Для увеличения срока годности картофельных клубней их хранят в холоде. Одним из неприятных следствий этого хранения является накопление в клубнях восстанавливающих сахаров (глюкоза, лактоза, мальтоза и др.). Во время термической обработки эти сахара реагируют со свободными аминокислотами, что вызывает образование горьких темноокрашенных продуктов. Вакуолярная инвертаза расщепляет сахарозу на глюкозу и фруктозу. Показано, что подавление экспрессии гена вакуолярной инвертазы методом РНК-интерференции, а также выключение гена методом TALEN приводит к снижению уровня восстанавливающих сахаров [1]. Система редактирования с использованием РНК-направленной эндонуклеазы Cas9 является одной из самых точных и эффективных для редактирования генов растений. Поэтому мы решили выбрать данную систему для получения нокаута S. tuberosum по гену вакуолярной инвертазы Pain-1.

Мы выбрали три сайта-мишени и соответствующие им нРНК на кодирующей последовательности гена Pain-1. Для каждой нРНК была создана конструкция, несущая кодон-оптимизированный для Arabidopsis thaliana ген нуклеазы cas 9 под убиквитиновым промотором Petroselinum crispum и ген нРНК под промотором U6-26 A.thaliana. Активность нРНК в данных конструкциях была оценена методами восстановления активности гена-репортера путем направленного внесения мутаций [2] и на протопластах картофеля. Также была создана конструкция, несущая все три нРНК, ген нуклеазы cas 9 , ген-репортер $m$ Cherry для стабильной биобалистической трансформации растений картофеля и конструкция с тремя нРНК и геном нуклеазы на основе бинарного вектора p6i (DNA Cloning Service, Hamburg, Germany) для стабильной агробактериальной трансформации.

Исследование поддержано грантом РНФ (16-16-04073) и Курчатовским геномным центром ИЦиГ (075-15-2019-1662).

\section{Список литературы}

1.Clasen B.M. et al. Improving cold storage and processing traits in potato through targeted gene knockout. Plant Biotechnol Journal. 2016; 14: 169-176.

2.Budhagatapalli N. et al. A simple test for the cleavage activity of customized endonucleases in plants. Plant Methods. BioMed Central. 2016; 12(1):18. 


\title{
Определение последовательности кластера рДНК у японского перепела
}

\author{
Жукова А.А. ${ }^{*}$, Галкина С.А. ${ }^{2}$, Комиссаров А.С. ${ }^{3}$, Сайфитдинова А.Ф. ${ }^{1,4}$ \\ ${ }^{1}$ Российский государственный педагогический университет им. А.И.Гериена, Санкт-Петербург, Россия \\ ${ }^{2}$ Санкт-Петербургский государственный университет, Санкт-Петербург, Россия \\ ${ }^{3}$ Университет ИТМО, Санкт-Петербург, Россия \\ ${ }^{4}$ Международный изентр репродуктивной медииины, Санкт-Петербург, Россия \\ *e-mail: gatteriyagreen@gmail.com
}

Ключевые слова: ядрышковый организатор, рибосомные гены, нанопоровое секвенирование

Мотивация и цеель: Ядрышковые организаторы (ЯОР) представляют собой участки генома, содержащие повторяющиеся кластеры генов рибосомной РНК $(18 \mathrm{~S}, 5,8 \mathrm{~S}, 28 \mathrm{~S})$. Они играют важную роль в образовании ядрышек, где происходит сборка субъединиц рибосом. Среди птиц на настоящий момент полная информация об организации кластера генов рРНК есть только для курицы [1]. Эта последовательность может служить референсной для сборки ЯОР других видов птиц за исключением видов, в кариотипе которых произошли структурные изменения, затрагивающие ЯОР. Кариотип японского перепела Coturnix japonica, в отличие от большинства птиц, имеет три пары ядрышкообразующих хромосом [2]. У этого вида, помимо анцестрального интерстициального ЯОР на хромосоме 16 , имеются еще два терминальных ЯОР на коротких плечах акроцентрических хромосом, образование которых могло быть связано с активностью мобильных элементов [3]. Цель настоящего исследования - определить последовательность кластера рибосомных генов $C$. japonica на основе длинных прочтений.

Meтоды и алгоритмы: Для анализа были использованы прочтения, полученные в результате нанопорового секвенирования соматической геномной ДНК C. japonica на приборе MinION (Oxford Nanopore Technologies). Выравнивание проводили с использованием последовательности рДНК домашней курицы (MG967540.1), что позволило определить границы между генами и спейсерами. В работе использовали инструменты BLAST, Homology segment analysis и Geneious.

Результаты: Был собран фрагмент кластера генов рРНК японского перепела длиной 13189 п.н., включая: ETS - 1298 п.н., 18S - 1777 п.н., ITS1 -1992 п.н., 5,8S- 157 п.н., ITS2 - 633 п.н., 28S - 4572 п.н., ETS - 2760.

Bblвoдbl: Полученная консенсусная последовательность может использоваться в качестве референсной при поиске полиморфных участков рДНК японского перепела и идентификации кластеров, локализованных на других хромосомах.

Благодарности: При выполнении работы была использована инфраструктура Ресурсного центра «ЦКП Хромас» Научного парка СПбГУ.

\section{Список литературь}

1. DyominA.G. et al. 2016. PLoS ONE, 11(6): e0157464. doi:10.1371/journal.pone.0157464.

2. McPherson M.C.et al. 2014. Chromosome Research, 22(1):71-83. doi:10.1007/s10577-014-9411-2.

3. Saifitdinova et al. 2019. Molecular Cytogenetics, 12(30):63. doi:10.1186/s13039-019-0439-z. 


\title{
Взаимосвязь активности сетей покоя мозга с динамикой риска депрессии и уровня тревожности у трудовых мигрантов в приполярных районах Якутии
}

\author{
Заварзин Е. ${ }^{1 *}$, Таможников С. ${ }^{2}$, Милахина Н. ${ }^{3}$, Борисова Н. ${ }^{4}$, Афанасьева Е. ${ }^{4}$, Никонов Н. ${ }^{5}$, \\ Чикачева С. ${ }^{5}$, Савостьянов А. ${ }^{1,2,3}$ \\ ${ }^{1}$ Новосибирский государственный университет, ЛБМСПЧ ГИ, Новосибирск, Россия \\ ${ }^{2}$ НИИ Физиологии и фундаментальной медищины, Новосибирск, Россия \\ ${ }^{3}$ Институт ицитологии и генетики СО РАН, Новосибирск, Россия \\ ${ }^{4}$ Северо-восточный федеральный университет им. М.К. Аммосова, Якутск, Россия \\ ${ }^{5}$ Якутский медицинский колледж, п. Хандыга, Республика Саха, Россия \\ *e-mail: zavarzinevg@gmail.com
}

Ключевые слова: ЭЭГ, ВDI, TA, функциональная коннективность, функциональные сети мозга

Мотивация и иели: ЭЭГ является относительно дешевым и мобильным средством изучения функциональной деятельности мозга. ЭЭГ, в частности, можно применять для обнаружения нейрофизиологических маркеров депрессивных расстройств и тревожности. В данном исследовании проведен поиск ассоциаций между ЭЭГ маркеры, отражающими функциональную активность сетей покоя мозга, с психологическими показателями, отражающими риск появления тревожно-депрессивных расстройств у трудовых мигрантов на территории Якутии. Цель: оценить взаимосвязь между состоянием сетей покоя мозга и изменением связанных с депрессией психологических показателей, наблюдавшихся в процессе адаптации к жизни в приполярном регионе.

Meтоды и алгоритмы: В обследовании приняло участие 50 здоровых мужчин, приехавших на учебу в Якутию из южных регионов, а также 50 здоровых студентов Медицинского колледжа в п. Хандыга. Каждый мигрант обследовался дважды - сразу же после переезда и через полгода после переезда. Регистрация ЭЭГ проведена в течение 12 минут без функциональной нагрузки. После записи ЭЭГ испытуемые заполняли комплект психологических опросников, включающий опросники на оценку уровня тревожности (тест Спилбергера, личностный профиль Айзенга) и тесты для оценки риска появления депрессии (методики Бека и Ахенбаха). Для анализа коннективности использовалась библиотека SPM, которая по ЭЭГ позволяла реконструировать источники сигнала и создавать маски связности функциональных систем мозга.

Результаты: Показано, что адаптация к якутскому климату сопровождается снижением тревожности у всех испытуемых, что сопровождается снижением мощности в диапазонах дельта и гамма ритма в медиальной коре. Уровень депрессивности у части мигрантов снижался, а у части повышался, что достоверно зависело от таких психологических маркеров как индивидуализм и коллективизм.

Кроме того, на ЭЭГ выявлено снижение степени коннективности дефолт-системы в процессе адаптации, что также коррелировало с показателями тревожности и депрессивности.

Заключение: ЭЭГ маркеры функциональных сетей мозга отражают динамику изменений связанных с депрессией психологических показателей в процессе адаптации мигрантов к приполярному климату. 


\title{
Сегментация и детекция структурных элементов колоса пшеницы
}

\author{
Заварзин Е. ${ }^{1 *}$, Приходько А. ${ }^{1}$, Прохошин Н. ${ }^{1}$, Комышев Е. ${ }^{2}$, Генаев M. ${ }^{1,2}$ \\ ${ }^{1}$ Новосибирский государственный университет, Новосибирск, Россия \\ ${ }^{2}$ Институт ичитологии и генетики СО РАН, Новосибирск, Россия \\ *e-mail: zavarzinevg@gmail.com
}

Ключевые слова: пшеница, колос, колоски, ости, феномика, компьютерное зрение, нейронные сети, сегментация, детекция

Мотивация и цель: Колос пшеницы — это сложное соцветие, для которого характерна удлиненная главная ось, на ней расположены сидячие одиночные колоски. Количество и тип посадки колосков определяют архитектонику колоса и влияют на многие показатели, в том числе на урожайность. Наличие остей - таксономический признак многих видов пшениц. При определении морфометрических признаков методами компьютерного зрения важным этапом является разделение колоса на области тела колоса и его ости. Цель работы: разработать метод компьютерного зрения для автоматической сегментации структурных элементов колоса пшеницы и детектирования отдельных колосков в колосе.

Meтоды и алгоритмы: Для решения задачи сегментации использовалась сверточная нейронная сеть архитектуры Unet [1] с энкодером resnet18 [2]. Разметка для обучения модели была получена автоматически на основе существующего алгоритма [3]. Для решения задачи детекции колосков обучалась модель, генерирующая бинарные маски колосков на основе обучающей выборки, где центры колосков аппроксимируются эллипсами. На основе этих масок производился поиск контуров колосков, подсчитывалось их количество, вычислялись их центры масс.

Результаты: Точность модели сегментации по метрике IoU составляет 0.90565 для тела колосса и 0.69115 для остей. Точность модели сегментации остей оказалась на $3 \%$ выше, чем у модели, представленной в статье [3]. Точность детекции колосков по метрике F1 составляет 0.9647.

Заключение: Для демонстрации работы предложенных моделей был разработан веб-сервис https://spikecv-demo.sysbio.ru. Пользователь может отправить свое изображение колоса или выбрать изображение из примеров. В результате будут предсказаны маски структурных элементов колоса, центры колосков и морфометрические характеристики колоса.

\section{Список литературы}

1. Zagoruyko S., Komodakis N. Wide residual networks. arXiv preprint arXiv:1605.07146. 2016.

2. Ronneberger O. et al. U-net: Convolutional networks for biomedical image segmentation. International Conference on Medical image computing and computer-assisted intervention. Springer, Cham, 2015;234-241.

3. Genaev M.A. et al. Morphometry of the Wheat Spike by Analyzing 2D Images. Agronomy. 2019, 9, 390. 
DOI 10.18699/SBB-2020-62

\title{
MGSGenerator 1.5: инструментарий для реконструкции математических моделей метаболических сетей
}

\author{
Казанцев Ф.В. ${ }^{1 *}$, Лашин С.А. ${ }^{1,2}$ \\ ${ }^{1}$ Курчатовский геномный иентр ИЦиГ СО РАН, Новосибирск, Россия \\ ${ }^{2}$ Новосибирский государственный университет, Новосибирск, Россия \\ *e-mail: kazfdr@bionet.nsc.ru
}

Ключевые слова: математические модели, E.coli, API, генерация модели, метаболические сети

\begin{abstract}
Мотивация и цель: Математическое моделирование широко используется в микробиологических исследованиях в задачах анализа метаболических сетей для оценки выхода целевого продукта или подборе оптимальных условий среды. Оно позволяет проверять тысячи вариантов наборов параметров. При моделировании нас интересует не только факт, но и характер взаимодействий: как они протекают в пространстве и во времени. Один из путей получения составных математических моделей - использование фреймовых моделей/стандартных уравнений для серии метаболических процессов. Однако для построения более точных моделей требуется повторно использовать существующие, уже адаптированные к экспериментальным данным модели подсистем. Мы представляем инструмент для получения полной математической модели по выбранной метаболической сети.

Результаты: Для реконструкции фреймовых моделей метаболических сетей мы доработали инструментарий MGSGenerator [1]. Новая версия - 1.5, позволяет выполнять следующие шаги: 1) декомпозиция поданной на вход сети на подсистемы, для последующей обработки; 2) каждая подсистема сравнивается с набором уже существующих моделей подсистем, собранных из нескольких источников. Основной источник готовых моделей - база данных MAMMOTh [2], в которой содержаться ферментативные реакции $E$. coli, адаптированные к экспериментальным данным; 3) если подходящей по структуре моделей не было найдено, запускается механизм построения фреймовых моделей, основанный на серии правил; 4) для того чтобы можно было сразу проводить вычислительные эксперименты, алгоритм добавляет в модель процессы притока в систему и вывода из системы веществ; 5) в конечном итоге получается SBML-модель, которая может быть передана в любой инструмент с поддержкой SBML.

Этот инструментарий был протестирован на серии метаболических сетей разных размеров, от одиночного метаболического пути, до метаболических сетей построенных по данным аннотированного генома бактерий.

Благодарности: Работа выполнена за счет финансирования Курчатовского геномного центра Федерального исследовательского центра ИЦиГ СО РАН, соглашение с Министерством образования и науки РФ № 075-15-2019-1662.
\end{abstract}

\section{Список литературы}

1. Казанцев Ф.В., Акбердин И.Р., Безматерных К.Д., Лихошвай В.А. Система автоматизированной генерации математических моделей генных сетей. Вестник ВОГиС. 2009, 13(1), 163-169.

2. Kazantsev F., I. Akberdin, S. Lashin, N. Ree, V. Timonov, A. Ratushnyi, T. Khlebodarova, Likhoshvai V. MAMMOTh: A new database for curated mathematical models of biomolecular systems. Journal Bioinformatics Computational Biol. 2018, vol. 16(01), pp. 1740010, 2018 https://doi.org/10.1142/S02197200174001. 
DOI 10.18699/SBB-2020-63

\title{
Роль ключевого белка мисматч репарации млекопитающих MSH2 в эпигенетических изменениях при онкогенезе
}

\author{
Каххарова 3.И.,2*, Грин И.Р., ${ }^{1,2}$ \\ ${ }^{1}$ Институт химической биологии и фундаментальной медицины СО РАН, Новосибирск, Россия \\ ${ }^{2}$ Новосибирский государственньй университет, Новосибирск, Россия \\ *e-mail: zarinkaapels@gmail.com
}

Ключевые слова: неканоническая мисматч репарация (нкММР), эксцизионная репарация ДНК (ЭРО), метилирование ДНК

Мотивация и цุель: У млекопитающих метилирование цитозина играет важную роль в регуляции транскрипции, при эмбриональном развитии и онкогенезе. В последние годы появляется все больше данных о том, что механизм эпигенетических изменений в ДНК на ранних стадиях онкогенеза связан с процессами мутагенеза и репарации, проходящими при участии ферментов эксцизионной репарации ДНК (ЭРО) и неканонической мисматч-репарации (нкММР). В предыдущей работе мы обнаружили [1], что интермедиаты ЭРО и модифицированные цитозины, расположенные по краям протяженного участка одной цепи ДНК (40-400 нуклеотидов) инициируют репарацию и деметилирование всего участка по пути нкММР. Если протяженный участок располагался в промоторной области гена, то опосредованное удаление всех mC путем нкММР приводило к активации экспрессии гена в клетках in vivo, что может объяснить гипометилирование промоторов онкогенов на ранних стадиях онкогенеза. Для изучения взаимосвязи воспалительного онкогенеза с механизмами репарации необходимо установление взаимосвязей между белками, участвующими в процессах транскрипции, репарации и метилирования ДНК.

Meтоды и алгоритмы: Поиск литературы был осуществлен в базе данных NCBI. Для поиска функциональных мотивов белков была использована база ELM. Для построения сети взаимодействия белков была использована программа Cytoscape со встроенной базой данных Spike. Результаты $u$ выводы: Биоинформатическим поиском по базам данных изучено взаимодействие белка MSH2, ключевого участника нкMМР, с белками других клеточных систем: транскрипцией, ЭРО, эксцизионной репарацией нуклеотидов, ДНК-метилазами и другими. Построены сети опосредованных взаимодействий, которые указывают на взаимосвязь процессов метилированиядеметилирования ДНК, что подтверждает гипотезу гипометилирования промоторных областей онкогенов и гиперметилирования промоторов генов онкосупрессоров как разных последствий одного процесса эпигенетических изменений на ранних стадиях онкогенеза с воспалительными процессами.

Финансирование: Исследование выполнено при финансовой поддержке РФФИ в рамках научного проекта № 18-29-07059.

\section{Список литературь}

1. Grin I., Ishchenko A.A. (2016) An interplay of the base excision repair and mismatch repair pathways in active DNA demethylation. Nucleic Acids Res. Vol. 44, P. 3713-3727. 


\title{
Влияние ферментов эксцизионной репарации оснований ДНК на активность АР-эндонуклеазы человека
}

\author{
Кладова О.А.*, Федорова О.С., Кузнецов Н.А. \\ Институт химической биологии и фундаментальной медицины СО РАН, Новосибирск, Россия \\ *e-mail: kladova@niboch.nsc.ru
}

Ключевые слова: эксцизионная репарация оснований, активность ферментов, полиморфизм

Мотивация и цель: Система эксцизионной репарации оснований (BER) представляет собой сложный многокомпонентный процесс, в котором поврежденная ДНК переносится от одного белка к другому. Известно, что некоторые участники BER способны оказывать влияние на активность друг друга. В данной работе изучали активность некоторых ферментов BER в экстрактах различных линий опухолевых клеток, а также провели исследование влияния ферментов репарации ДНК на активность АР-эндонуклеазы человека (APE1) и ее природных полиморфных вариантов (SNP).

Meтоды $и$ алгоритмы: Для определения активности ферментов репарации ДНК использовали короткие ДНК-зонды, содержащие флуоресцентные метки FAM/BHQ1 и поврежденный нуклеотид, обеспечивающий специфичность к определенному ферменту. Исследование активности ДНКгликозилаз и АР-эндонуклеазы проводили на культурах клеток HEK293T, A549, WT, 786-0, HeLa, HKC8 и MCF7. Регистрацию расщепления ДНК-зонда при взаимодействии с очищенным препаратом APE1 дикого типа и SNP вариантов, содержащих замены R221C, N222H, R237A, G241R, M270T, R274Q и P311S, проводили, используя спектрофлуориметр остановленного потока.

Pезультаты: При исследовании активности ферментов репарации ДНК в экстрактах опухолевых клеток было показано, что уровень активности ферментов репарации, взаимодействующих с ДНКзондами, содержащими АР-сайт, 5,6-дигидроуридин и уридин, был выше в раковых линиях по сравнению с нормальными клетками почки человека НКС8. При анализе белок-белкового влияния ферментов участников BER на APE1 дикого типа и SNP варианты, было показано, что мутантные формы АР-эндонуклеазы стимулируются по-разному. Установлено, что белки AAG, OGG1, Polß и XRCC1 значительно стимулировали WT APE1 и мутантные формы R237A и P311S. Незначительный эффект наблюдался для других полиморфных вариантов (R221C, N222H, G241R, M270T, R274Q), что указывает на то, что эти аминокислотные остатки могут участвовать в белокбелковых взаимодействиях при репарации повреждений. Интересно отметить, что UNG2 и PCNA незначительно стимулировали WT APE1, снижали активность R221C, M270T и R274Q и не оказывали влияния на N222H и G241R.

Заключение: Используя короткие ДНК-зонды был определен уровень активности некоторых ферментов BER в клеточных лизатах различных культур клеток, а также установлено влияние отдельных ДНК-гликозилаз и других белков репарации ДНК на активность АР-эндонуклеазы дикого типа и ее природных полиморфных вариантов.

Благодарности: Работа выполнена при поддержке гранта МД-3775.2019.4. 


\title{
Особенности редиса европейского при получении DH-растений в культуре микроспор in vitro
}

\author{
Козарь Е.В.*, Домблидес Е.А., Солдатенко А.В. \\ ФГБНУ «Федеральный научный иентр овощеводства», Московская область, Россия \\ *e-mail:koz_leno4ek@gmail.com
}

Ключевые слова: редис европейский, Raphanus sativus L., культура микроспор in vitro, IMC

Мотивация и иель: Разработка технологии получения удвоенных гаплоидов (DH-растений) в культуре изолированных микроспор in vitro (IMC) является приоритетной задачей для практической селекции. Редис европейский (РЕв) является самой неотзывчивой культурой к IMC технологии в семействе Brassicaceae Burn. и эффективная IMC технология для него пока не разработана. С целью разработки модификаций для повышения эффективности IMC технологии мы исследовали биологические особенности развития мужского гаметофита РЕв, его способности к эмбриогенезу и последующей регенерации в in vitro на разных этапах.

Meтоды и алгоритмы: За основу была взята методика, разработанная в лаборатории биотехнологии ФГБНУ ФНЦО для культуры микроспор семейства Brassicaceae [1].

Результаты: Выявлено, что одна из основных причин слабой индукции эмбриогенеза у РЕв неоднородность созревания микроспор в бутонах. Обнаружена генотип-зависимая корреляция между линейной длиной бутонов и оптимальной стадией развития микроспор. При стандартной методике изолирования микроспор РЕв, в суспензионной культуре присутствует много посторонних включений, что может оказывать негативное влияние на индукцию эмбриогенеза и процесс развития эмбриоидов. На этапе укоренения апикальных побегов РЕв в условиях in vitro обнаружена высокая склонность DH-растений к опухолеобразованию, что может приводить к полной потере растений при использовании стандартной методики для семейства Brassicaceae.

Заключение и доступность: Изучение особенностей РЕв при получении $\mathrm{DH}-$ растений с помощью IMC технологии позволили продвинуться в разработке модификаций по усовершенствованию стандартного протокола семейства капустные и повысить его эффективность для Рев [2, 3].

Acknowledgements: The reported study was funded by RFBR, project number No. 19-316-90034.

\section{Список литературь}

1. Домблидес Е.А., Шмыкова Н.А., Шумилина Н.А., Заячковская Т.В., Минейкина А.И., Козарь Е.В., Ахраменко В.А., Шевченко Л.Л., Кан Л.Ю., Бондарева Л.Л., Домблидес А.С. Технология получения удвоенных гаплоидов в культуре микроспор семейства капустные (методические рекомендации). М.: ВНИИССОК, 2016.

2. Kozar E.V., Domblides E.A., Soldatenko A.V. Factors affecting DH plants in vitro production from micro- spores of European radish. Vavilov Journal Genetics Breeding. 2020;24(1):31-39. DOI 10.18699/VJ20.592.

3. Kozar E.V., Kozar E.G., Soldatenko A.V., Domblides E.A. Rooting technique of double haploids obtained in culture of microspore for European radish.Vegetable Crops Russia. 2020 (in print). 


\section{Нейротрофическое обеспечение коры головного мозга при болезни Альцгеймера: транскриптомный анализ}

Козлова Т.А.*, Рудницкая Е.А., Стефанова Н.А., Колосова Н.Г.

Институт цитологии и генетики СО РАН, Новосибирск, Россия

*e-mail: Kozlovatanya21@gmail.com

Ключевые слова: болезнь Альцгеймера, нейротрофические факторы, RNA-Seq, крысы OXYS

Мотивация и цель: болезнь Альцгеймера (БА) - наиболее распространенная форма сенильной деменции. Изменение с возрастом нейротрофического обеспечения головного мозга может вносить вклад в развитие БА, однако механизмы, лежащие в его основе, изучены недостаточно из-за невозможности исследовать эти процессы в динамике у людей, а также отсутствия адекватных биологических моделей. Уникальной моделью БА является линия крыс OXYS. Цель работы исследование динамики изменения сигнального пути нейротрофинов в коре головного мозга крыс OXYS при развитии признаков БА и в post mortem образцах коры головного мозга пациентов с БА. Материальы и методы: массовое параллельное секвенирование (RNA-Seq) префронтальной коры крыс OXYS и Вистар (контроль) проводили в ЗАО «Геноаналитика» (г. Москва). Данные RNA-seq префронтальной коры пациентов с БА и когнитивно здоровых людей получали из базы данных DDBJ Sequence Read Archive, \#SRA060572. Анализ изменения экспрессии генов сигнального пути нейротрофинов проводили, используя базы данных KEGG и DAVID.

Peзультаты: анализ транскриптома префронтальной коры головного мозга крыс OXYS и Вистар показал, что в период манифестации признаков БА у крыс OXYS (с 20 дней до 5 мес.) имеют место сходные изменения экспрессии генов сигнального пути нейротрофинов в коре головного мозга крыс обеих линий: уровень мРНК 45 генов изменялся однонаправленно. В период усиленной прогрессии признаков БА (с 5 до 18 мес.) количество дифференциально экспрессирующихся генов сигнального пути нейротрофинов у крыс OXYS было на порядок больше, чем у крыс Вистар. Важно отметить, что с возраста 20 дней до 18 мес. в коре головного мозга крыс OXYS однонаправленными были изменения экспрессии только 3 генов, а экспрессия 30 генов изменялась разнонаправлено. Анализ данных транскриптома префронтальной коры пациентов с БА и когнитивно здоровых людей показал, что у пациентов с БА изменен уровень мРНК 20 генов сигнального пути нейротрофинов, 15 из которых имели сниженную экспрессию, связанную с негативной регуляцией актинового цитоскелета и роста аксонов, ареста клеточного цикла и дифференцировки клеток, нейрональной пластичности. Повышенный уровень мРНК 5 генов сигнального пути нейротрофинов ассоциирован с дисрегуляцией ретроградного транспорта, а также выживаемости клеток и их гибели.

Заключение: таким образом, развитие признаков БА сопровождается дисрегуляцией сигнального пути нейротрофинов в перфронтальной коре головного мозга. Результатом этой дисрегуляции может стать подавление сигнального пути нейротрофинов, наблюдаемое у пациентов с БА. Благодарности: работа поддержана грантом РНФ № 19-15-00044. 
DOI 10.18699/SBB-2020-67

\section{Идентификация регуляторного гена, контролирующего синтез кутикулярного воска ячменя}

Колосовская Е.В. ${ }^{1,2 *}$, Герасимова С.В. ${ }^{1,2}$, Короткова А.М. ${ }^{1}$, Хертиг К. ${ }^{3}$, Морозов С.В. ${ }^{4}$, Черняк Е.И. ${ }^{4}$, Домрачев Д.В. ${ }^{4}$, Кочетов А.В. ${ }^{1,2}$, Кумлен Й. ${ }^{3}$, Хлесткина Е.К. ${ }^{1,2,5}$

${ }^{1}$ Институт цитологии и генетики СО РАН, Новосибирск, Россия

${ }^{2}$ Новосибирский государственный университет, Новосибирск, Россия

${ }^{3}$ Институт генетики растений и исследований культурных растений, Германия, Гатерслебен

${ }^{4}$ Новосибирский институт органической химии СО РАН, Новосибирск, Россия

${ }^{5}$ Всероссийский институт растениеводства имени Н. И. Вавилова, Санкт-Петербург, Россия

*e-mail: e.kolosovskaia@g.nsu.ru

Ключевые слова: ячмень, Hordeum vulgare, Cas9/gRNA, эпикутикулярный воск, обратная генетика

Мотивация и цель: Сайт-специфический мутагенез открывает новые перспективы для решения проблем обратной генетики. Одно из направлений в этой области - использование системы Cas9/gRNA для изучения функций регуляторных генов. В настоящей работе в качестве мишени был выбран ген ячменя (Hordeum vulgare) подсемейства WIN1/SHN1, кодирующий транскрипционный фактор, который участвует в формировании устойчивости к биотическому стрессу. Этот ген принадлежит к семейству APETALA2 / Ethylene Responsive Factor (AP2/ERF), играющему роль в процессах роста, развития, реакции на стресс. Целевой нокаут гена HvWIN1/SHN1 привел к рецессивному фенотипу дефицита кутикулярного воска.

Meтоды и алгоритмы: Первичные (M1 = T0) мутанты ячменя (сорт «Golden Promise») были получены путем целевого нокаута гена HvWIN1 с использованием системы Cas9/gRNA. Шесть линий без Т-ДНК, несущие различные гомозиготные мутации были отобраны в поколении М4. Ультраструктуру и биохимический состав воска исследовали с помощью сканирующей электронной микроскопии и газовой хроматографии в сочетании с масс-спектрометрией.

Результаты: Микрофотографии и измерения воска показали, что мутантные растения и растения дикого типа накапливают одинаковое количество воска на листовых пластинках. Напротив, воск листовых влагалищ мутантных растений заметно отличается от такового у дикого типа как по общему количеству, так и по составу отдельных компонентов, включая алканы, спирты и дикетоны. Заключение: Природа мутантного фенотипа и полученные данные позволяют предположить, что транскрипционный фактор HvWIN1/SHN1 в норме регулирует синтез кутикулярного воска на поверхности влагалищ верхних листьев ячменя.

Благодарности: Работа поддержана грантом РНФ 16-14-00086. Работа выполнена на оборудовании ЦКП «Микроскопического анализа биологических объектов» Центрального Сибирского ботанического сада СО РАН (Новосибирск, Россия). 


\title{
Получение линий растений мутантов и анализ полученных популяций после геномного редактирования по гену $\mathrm{Nud}$ у ячменя
}

\author{
Короткова А.М. ${ }^{1}$, Колосовская Е.В. ${ }^{1}$, Герасимова С.В. ${ }^{1}$, Кукоева Т.В. ${ }^{1}$, Хлесткина Е.К. ${ }^{1,2}$ \\ ${ }^{1}$ ИЦиГ СО РАН, Новосибирск, Россия \\ ${ }^{2}$ ВИР, Санкт Петербург, Россия \\ *e-mail: korotkova@bionet.nsc.ru
}

Ключевые слова: CRISPR/Cas, ячмень, Nud, геномное редактирование, пленчатость, голозерность

Мотиващия и цель: Методы геномного редактирования растений бурно развиваются в последние годы [1], однако работ по редактированию ячменя не много, что обусловлено сложностью редактирования геномов однодольных растений [2].

После проведения геномного редактирования ячменя методом CRISPR/Cas по гену Nud были получены ряд мутантов, несущих целевые и нецелевые муации. Среди многообразия мутантов были отобраны те, что несут только мутации в гене Nud и немутантны по остальным генам. Ген Nud является транскрипционным фактором, ответственным за образование липидного слоя на поверхности зерна, который, при созревании, приводит к прилипанию чешуек к зерну и формированию свойства пленчатости зерна. Целью работы был отбор голозерных линий растений с мутациями в гене Nud.

Meтоды и алгоритмы: С помощью двух разных направляющих-РНК (Nud45 и Nud50) методом геномного редактирования CRISPR/Cas, нами были получены растения T0 с различными мутациями в четырех генах: Nud (целевой), Win1 и двух безымянных генах расположенных на хромосомах 6H и 7Н ячменя (нецелевые мутации). Геномное редактирование проводилось на сорте Golden promise. Всего было получено 50 растений T0 Nud45 и 49 растений Nud50, среди которых встречались и гетерозиготы и дикий тип и растения с биаллельной мутацией. Во второе поколение Т1 были отобраны интересующие нас мутации для выведения их в гомозиготное состояние. По 9 растений из группы Nud45 и Nud50. В том числе была выделена линия дикого типа в качестве контрольной группы. Растения были проверены на наличие трансгена и среди нетрансгенных выделены три линии Nud50 с мутациями в гене Nud $(-3),(+1)$ и (-1). Все три линии растений несут в себе свойство голозерности. Растения были высажены в теплице. Из каждого растения выделена ДНК. При помощи секвенирования было подтверждено единообразие последовательностей гена Nud в каждой линии. Проведен сноповой анализ и сравнение с контролем.

Pезультаты: В результате отбора были выделены три линии растений с мутациями в гене Nud (-3), $(+1)$ и $(-1)$. Все три линии растений несут в себе свойство голозерности. Выполнено сравнение трансформантов с контрольными растениями по параметрам снопового анализа. Отобраны мутанты из группы Nud45. Обработка результатов второй группы растений еще в процессе.

Исследование выполнено за счет гранта Российского научного фонда (проект № 16-14-00086).

Список литературь

1. Korotkova A.M., Gerasimova S.V., Khlestkina E.K. Current achievements in modifying crop genes using CRISPR/Cas system. Vavilov Journal Genetics Breeding. 2019. 23(1). P. 29-37.

2. Gerasimova S.V., Khlestkina E.K., Kochetov A.V., Shumny V.K. Genome editing system CRISPR/CAS9 and peculiarities of its application in monocots. Russ. J. Plant Physiol. 2017. V. 64(2). P. 141-155. 


\section{Геномное редактирование цианобактерий с целью получения промышленно значимых продуктов}

Кувырченкова А.П.

Национальный исследовательский центр «Курчатовский институт», Москва, Россия e-mail: kuvyrchenkova@phystech.edu

Ключевые слова: цианобактерия, геномное редактирование, производство продукта

Мотивация и цель: Цианобактерии - это фотоавтотрофные бактерии, которые содержат хлорофилл «а» и осуществляют фотосинтез сходным образом с высшими растениями. Преимущество использования данных микроорганизмов в том, что они нуждаются только в солнечном свете, воде и воздухе. Выбор же продукта, который будет производит цианобактерия, зависит от нескольких факторов: прежде всего производство должно быть экономически выгодно, в том числе по сравнению с традиционными способами производства данного продукта, производимый продукт должен легко выделяться из среды с цианобактериями, не менее важна безопасность для человека самого продукта и производства в целом, относительная автономность производства продукта также является преимуществом при выборе.

Meтоды и алгоритмы: Генетичекий перенос молекулы ДНК в клетку цианобактерии может быть осуществлен в результате электропорации или естественных способов передачи ДНК: трансформации, коньюгации и трансдукции. Трансформируемый генетический материал возможно получить из других организмов, производящих интересуемый нас продукт.

Одноклеточная цианобактерия Synechococcus sp. PCC 7942 первая цианобактерия, для которой описана генетическая трансформация [1]. Затем трансформация была описана для штамма одноклеточной цианобактерии Synechocystis. sp. PCC 6803 [2], способного расти в темноте на глюкозе [3]. Этот штамм сыграл главную роль в изучении цианобактериального фотосинтеза.

Заключение: Цианобактерии представляют собой значительный, но на данный момент малоиспользуемый, ресурс для получения огромного количества различных промышленно значимых продуктов. Все чаще появляются разработки с использованием этих древнейших микроорганизмов. Простота в уходе и доступность методов геномного редактирования цианобактерий позволяет найти им применение в биотехнологии для производства специфических продуктов, включая биотопливо, лекарственные препараты, продукцию косметической промышленности, а также многие другие необходимые продукты.

Благодарности: источник финансирования Соглашение с Минобрнауки № 075-15-2019-1659 от 31.10.2019

Список литературь

1. Shestakov S.V., Khyen N.T. Mol. Gen. Genet. 1970. V. 107. P. 372.

2. Grigorieva G., Shestakov S. FEMS Microbiol. Lett. 1982. V. 13. P. 367.

3. Anderson S.L., McIntosh L. J. Bacteriol. 1991. V. 173. P. 2761. 


\title{
Влияние экзогенных конечных продуктов глубокого гликирования на первичный метаболом культуры Rhizobium leguminosarum
}

\author{
Кузнецова А. ${ }^{1 *}$, Шумилина Ю. ${ }^{1}$, Династия Е. ${ }^{1,2,3}$, Илинг К. ${ }^{4}$, Попова В. ${ }^{1,2}$, Гришина T. ${ }^{1}$, \\ Васко В.А. ${ }^{2}$, Зинц А. ${ }^{4}$, Вестерманн Б. ${ }^{2}$, Фролов А. ${ }^{1,2}$ \\ ${ }^{1}$ Санкт-Петербургский государственный университет, Кафедра Биохимии, Санкт-Петербург, Россия \\ ${ }^{2}$ Институт биохимии растений им. Лейбница, Департамент Биоорганической Химии, Халле, Германия \\ ${ }^{3}$ Институт органического синтеза им. И.Я. Постовского Уральского отделения Российской академии наук, \\ Екатеринбург, Россия \\ ${ }^{4}$ Университет им. Мартина Лютера Галле-Виттенберг, Халле, Германия \\ *e-mail:alena_kyy@mail.ru
}

Ключевые слова: конечные продукты глубокого гликирования (КПГГ), первичные меаболиты, ризобии, Rhizobium leguminosarum

Мотивация и цель: Ризобиальные бактерии - это азотфиксирующие почвенные микроорганизмы, способные образовывать симбиотические ассоциации - клубеньки на корнях бобовых растений. Являясь одним из партнеров симбиоза, они в значительной степени оказывают влияние на урожайность бобовых культур. Показано, что старение и стресс у растений сопровождаются накоплением конечных продуктов глубокого гликирования (КПГГ) [1]. Однако вопрос влияния экзогенных КПГГ на ризобии остается малоизученным. Поэтому, целью данной работы было изучение влияния экзогенных КПГГ, в частности $N^{\delta}$-(5-метил-4-имидазолон-2-ил) орнитина (MGН1), на метаболом ризобий.

Mетоды и алгоритмы: Культура Rhizobium leguminosarum bv viciae RCAM1026 была проинкубирована с 25 мкмоль/л MG-H1 в течение 0,5 и 18 часов. Из ризобий были выделены первичные метаболиты методом водно-метанольной экстракции. Анализ первичных метаболитов проводился при помощи газовой хроматорафии, сопряженной с квадрупольной массспектрометрией с электронным ударом (EI-Q-MS). Поиск и идентификация метаболитов были проведены с использованием программных пакетов AMDIS, MSDIAL и Xcalibur 3.0, а также программного обеспечения MetaboAnalyst.

Результаты: В ходе анализа экспериментальных и контрольных образцов $R$. leguminosarum было обнаружено 62 первичных метаболитов. При этом, добавление MG-H1 в культуральную среду способствовало повышению уровня метаболитов, вовлеченных в энергетические процессы клетки. Заключение: Добавление MG-H1 в питательную среду вызвало изменения в первичном метаболомеризобий, выражающиеся в усилении процессов энергетического обмена. Однако механизмы, лежащие в их основе, еще предстоит выяснить.

Благодарности: Работа выполнена при поддержке Российского фонда фундаментальных исследований (проект 18-016-00190).

Список литературы

1. Paudel G. et al. Osmotic stress isaccompanied by protein glycation in Arabidopsis thaliana. J Exp Bot. 2016;67:62836295. 


\title{
Разработка алгоритмов для нахождения факторов транскрипции и их сайтов связывания в аннотированных бактериальных геномах
}

\author{
Лахова Т.Н. ${ }^{*}$, Ощепков Д.Ю. ${ }^{1}$, Мухин А.М. ${ }^{1}$, Лашин С.А. ${ }^{1,2}$ \\ ${ }^{1}$ Курчатовский геномный иеентр, Институт ичитологии и генетики СОРАН, Новосибирск, Россия \\ ${ }^{2}$ Новосибирский государственный университет, Новосибирск, Россия \\ *e-mail: tlakhova@bionet.nsc.ru
}

Мотивация и цеель: В эпоху появления секвенирования нового поколения (NGS) стремительно увеличились объемы данных о геномах организмов, в том числе и бактериальных. Однако быстро растущий объем этих данных намного опережает их анализ и понимание того, как на уровне последовательности гены регулируются в этих геномах. На сегодняшний день известно, что регуляция транскрипции у бактерий осуществляется с помощью ряда механизмов, в основе которых лежат транскрипционные факторы (ТФ) [1]. Но все же остается малоизученным какое количество генов имеет регуляторные механизмы.

Meтоды и алгоритмы: В рамках данной работы информация о ТФ бактерий была взята из БД: CollecTF и UniprotDB. C помощью Blast+ осуществлялось выравнивание на аннотированные геномы бактерий. Обработка полученных данных после выравнивания и отбор подходящих кандидатов ТФ, а также ряд алгоритмов выполнялись с помощью Руthon и ряда библиотек. Вебсервис Operon-mapper [2] использовался для распознавания оперонов в бактериальных геномах. Данная информация необходима для нахождения промоторных районов, которые послужат отправной точкой для дальнейшего определения ССТФ.

Результаты: На сегодняшний день разработан рабочий вариант алгоритма по поиску ТФ в геноме бактерии на основе имеющейся информации о ТФ из БД CollecTF. Реализован алгоритм для получения межоперонных интервалов на языке Python с помощью библиотек: pandas, numpy и biopython. Проведено тестирование полученного алгоритма на геномах модельных организмов из базы данных NCBI. В случае сборки генома до нескольких скаффолдов, проведена предобработка файлов, полученных с веб-сервиса Operon-mapper. Алгоритм находится на стадии адаптации для данных секвенирования геномов бактерий из коллекций участников консорциума Курчатовского геномного центра.

Благодарности: Работа выполнена за счет финансирования Курчатовского геномного центра Федерального исследовательского центра ИЦиГ СО РАН, соглашение с Министерством образования и науки РФ № 075-15-2019-1662.

\section{Список литературь}

1. Toyoda K., Inui M. Regulons of global transcription factors in Corynebacterium glutamicum. Appl. Microbiol. Biotechnol. 2016. Vol. 100, № 1. P. 45-60.

2. Taboada B. et al. Operon-mapper: A web server for precise operon identification in bacterial and archaeal genomes. Bioinformatics. 2018. Vol. 34, № 23. P. 4118-4120. 
DOI $10.18699 / \mathrm{SBB}-2020-72$

\title{
Новый вид байкальской эндемичной губки: морфологический и молекулярно- генетический анализ (на основе полного митохондриального генома)
}

\author{
Майкова О.О. \\ Лимнологический институт СО РАН, Иркутск, Россия \\ e-mail:maikova@lin.irk.ru
}

Ключевые слова: озеро Байкал, губки, мтДНК, эволюция

Мотивация и цеель: в 2016 году во время экспедиции по озеру Байкал была найдена губка по морфологии внешнего вида, спикул и скелета не имеющая аналогов в современной систематике байкальских эндемичных губок (сем. Lubomirskiidae). Нами она была описана как новый вид рода Swartschewskia - S. khanaevi [1]. С точки зрения эволюции этот вид вызывает к себе особый интерес. Спикулы, схожие со спикулами S.khanaevi были обнаружены в отложениях Байкала, датируемые Поздним Плейстоценом (3.2-2.8 млн. л. н.). Эти спикулы были отнесены к вымершему виду Paleoswartschewskia sp. [2]. С целью изучения молекулярной эволюции нового вида был определен его полный митохондриальный геном.

Meтоды и алгоритмы: образец губки был идентифицирован до вида по результатам анализа спикул и скелета под микроскопом. Суммарная ДНК была выделена из ткани губки путем экстракции в СТАВ-буфере. Митохондриальный геном амплифицирован и секвенирован по ранее опубликованной методике (Maikova et. al., 2015). Фрагменты мтДНК были собраны при помощи программы MAFFT v 6.882. Филогенетический анализ проведен на основе 14 белок-кодирующих генов мтДНК байкальских губок (6 видов) байесовским методом с помощью программы MrBayes v. 3.2.6.

Pезультаты: определена нуклеотидная последовательность полного митохондриального генома нового вида байкальской эндемичной губки S. khanaevi. Длина генома составила 26638 н.п. На филогенетическом древе вид $S$. khanaevi кластеризуется с другим представителем рода Swartschewskia. Показана повышенная скорость накопления нуклеотидных замен у S. khanaevi относительно других видов семейства Lubomirskiidae в 2,5 раза.

$B b l в о д:$ на основе данных митохондриального генома подтверждено, что новый вид относится к семейству Lubomirskiidae, роду Swartschewskia. Выявлена такая особенность эволюции мтДНК нового вида, как повышенная относительная скорость накопления нуклеотидных замен в белоккодирующих генах.

Благодарности: поддержано грантом РФФИ № 19-04-00787А.

Список литературы

1. Bukshuk N.A., Maikova O.O. A new species of Baikal endemic sponges (Porifera, Demospongiae, Spongillida, Lubomirskiidae). ZooKeys. 2020; 906: 113-130.

2. Veynberg E. Fossil Sponge Fauna in Lake Baikal Region. In: Müller W.E.G., Grachev M.A. (Eds) Biosilica in Evolution, Morphogenesis, and Nanobiotechnology. Springer, Berlin Heidelberg. 2009; 185-205. 


\title{
Применение генетических и биоинформационных подходов к познанию биоразнообразия на примере эндемичных рыбьих пиявок Baicalobdella (Hirudinea, Piscicolidae) из озера Байкал
}

\author{
Матвеенко Е.Ю. *, Кайгородова И.А. \\ Лимнологический институт СО РАН, Иркутск, Россия \\ *e-mail:matveenko@lin.irk.ru
}

Ключевые слова: филогенетическое разнообразие, криптические виды, Baicalobdella, Байкал

Мотивация и цель: Экологические исследования требуют точного и быстрого определения уровней биоразнообразия без использования традиционного морфологического анализа. Для решения этой задачи разработан целый ряд методов молекулярной экологии. В данной работе был апробирован набор биоинформационных методов, обеспечивающих объективную оценку различий между внутривидовой и межвидовой вариабельностью. В качестве модельного объекта использован набор нуклеотидных последовательностей фрагмента coxl двух популяций пиявок рода Baicalobdella (Dogiel, 1957), паразитирующих на эндемичных амфиподах Байкала, и трудно идентифицируемых морфологически.

Материалы и методы исследования: Биологический материал отобран по всей акватории оз. Байкал и в верхнем течении р. Ангара в диапазоне глубин 0-285 м. Морфологическое определение видовой принадлежности проведено в соответствии с исходным и более поздним дополненным описанием вида. Для молекулярного анализа использовали фрагмент гена, кодирующего coxl, широко применяемый в ДНК-штрихкодировании. Биоинформационный анализ генетических данных проводился на основе нескольких альтернативных методов, включая байесовский метод, реализованный в BEAST v. 1.8.4, алгоритм GMYC, программа ABGD и пакет программ MEGA 7. Результаты и обсуждение: Согласно современной классификации 65 образцов были отнесены к виду B. torquata. Однако в этой группе уровень генетического полиморфизма (р) составляет $0,049 \pm$ 0,006, что вдвое превышает пороговое значение. Согласно теории ДНК-штрихкодирования coxl анализ выявил две четко выраженные клады в пределах филогенетической линии B. torquata. Подразделение вида соотносится с географической приуроченностью образцов к северной и южной котловинам озера. Высокий показатель генетических различий между северной и южной популяциями составляет 0,089 $\pm 0,011$ и свидетельствует о существовании в оз. Байкал криптического комплекса, состоящего как минимум из двух видов байкалобделл. Дополнительный биоинформационный анализ с применением альтернативных алгоритмов (GMYC и ABGD) поддерживает гипотезу генетической дивергенции B. torquata на два вида.

Благодарности: Авторы признательны Н.В. Сороковиковой и М.А. Агееву за вклад в коллекцию пиявок. Работа выполнена при финансовой поддержке РФФИ (проекты № 17-29-05097 и № 20-3490043). 


\section{Поиск и оценка белков нуклеаз II класса в геномных и метагеномных данных}

Медведев Д.О.*, Желтова А.В.

НИЦ «Курчатовский институт», Москва, Россия

*e-mail:d.o.medvedev@gmail.com

Ключевые слова: CRISPR-Cas, Cas, редактирование генома, ДНК-нуклеазы, Cas12, Cpf1

Мотивация и цель: В прикладном аспекте CRISPR-Cas стал революцией в генной инженерии. Как известно, эффекторы CRISPR-Cas делятся на два больших класса (I и II), на основе структуры эффекторного белка: системы Класса II имеют в качестве эффектора один белок (Cas9, Cas12 (CasX, CasY, Cpf1), Cas13), размером 800-1900 аминокислот [1]. На сегодняшний день репертуар известных эффекторных белков весьма ограничен, а практически используемым эффекторам присущ ряд недостатков. Основной задачей данной работы является анализ инструментов, методов и баз данных для биоинформатического поиска CRISPR-систем в геномных массивах данных с целью расширения спектра известных Cas-эффекторов.

Meтоды и алгоритмы: Был проведен биоинформатический поиск с последующим анализом с целью выявления новых РНК-управляемых ДНК-нуклеаз. Для поиска был применен алгоритм оценки белкового окружения в области обнаруженных белков адаптации обновленных профилей Cas1, Cas2, Csn2 и CRISPR-касет. В ходе работы алгоритма выявляются открытые рамки считывания, каждая из которых проходит аннотации по известным источникам. С помощью алгоритма PSIBLAST были найдены далекие гомологи каждого из белков. Для дальнейшей работы белки были преоретизированы по следующим критериям: процент сходства с известными и используемыми белками, вероятность функциональности домена, размер, оптимум температуры бактерии-хозяина. Результаты: Было отобрано 326 ранее не аннотированных белков, имеющих в своей последовательности нуклеазные домены. Среди отобранных белков была выявлена, наиболее отдаленная от известных последовательностей, находка. Для находки, на основе полученных нуклеотидных сиквенсов, из экспериментальных семплов было предсказано: наличие нуклеазной активности, характеризуйся согласно систематизации, выявление ключевых доменов и аминокислот.

Заключение и доступность: Полученная находка относиться белкам ко второму классу, пятого типа, подтипу А. Анализа множественного выравнивания гомологов белка, а также моделирование структуры по гомологии позволили выявить особенности организации доменов и определить функциональные аминокислоты. Полученные данные, с высокой вероятностью, указывают, что ранее не охарактеризованная находка обладает нуклеазной активностью белков второго класса CRISPR-Cas.

Список литературь

1. Dudek N.K. и др. Novel microbial diversity and functional potential in the marine mammal oral microbiome. Curr. Biol. 2017;27(24):3752-3762.e6. 


\title{
Использование фототрофных микроорганизмов для очистки сточных вод и получения биоудобрений
}

\author{
Мельникова А. ${ }^{1 *}$, Kuchendorf C. ${ }^{2}$, Комова А. ${ }^{1}$, Руденко А. ${ }^{1}$, Намсараев $3 .{ }^{1}$ \\ ${ }^{1}$ Национальный исследовательский иентр «Курчатовский институт», Москва, Россия \\ ${ }^{2}$ Forschungszentrum Jülich GmbH, Jülich, Germany \\ *e-mail: annfairstar@mail.ru
}

Ключевые слова: сточные воды, фотосинтезирующие микроорганизмы, азот, фосфор

Мотивация и цель работы: Высокое содержание азота и фосфора в сточных водах является одной из основных проблем при очистке стоков различного происхождения. Так как соединения азота и фосфора активно участвуют в метаболизме живых существ, при очистке сточных вод широко распространено использование микроорганизмов для аккумуляции этих веществ внутрь клетки. При этом по окончании культивирования возникает необходимость сбора и утилизации биомассы. Целью нашей работы была разработка способа культивирования фототрофных микроорганизмов на средах с высоким содержанием азота и фосфора, позволяющего эффективно проводить последующую утилизацию полученной биомассы.

Meтоды: В ходе работы штамм Chlorella sp. C1 (коллекция Forschungszentrum Jülich GmbH, Германия) культивировался на стандартной питательной среде Trebon различных концентраций (x1, $\mathrm{x} 2, \mathrm{x} 3, \mathrm{x} 5)$. Освещение и температура были постоянными: $40 \mu \mathrm{E}$ и $23{ }^{\circ} \mathrm{C}$. Аэрация происходила за счет беспрерывной циркуляции среды с помощью помпы. Клетки хлореллы были иммобилизованы в $2 \%$ альгинатном геле на подложке в виде хлопчатобумажной ткани. По окончанию исследования было измерено содержание в геле хлорофиллов $a$ и $b$. При утилизации отработанного материала его использовали как биоудобрение для кресс-салата Lepidium sativum. В ходе работы каждый день отбирались пробы для измерения содержания общего азота и фосфора фосфатов.

Результаты: Для проведения исследований был создан горизонтальный наклонный фотобиореактор, имитирующий поверхностный сток. Было показано, что микроводоросли внутри разработанного нами биодеградируемого материала поглощают азот и фосфор значительно быстрее, чем в суспензии и при иммобилизации внутри альгинатных сфер. Также было показано, что после высушивания разработанного нами материала и его хранения в течение 28 дней при н.у. микроводоросли не теряют способность аккумулировать биогенные вещества. При использовании материала с выросшими микроводорослями в виде удобрения кресс-салат рос и развивался быстрее, чем в контроле без микроводорослей.

Bывод: Был разработан природоподобный материал, способный эффективно концентрировать биогенные элементы в условиях, приближенных к условиям сточных вод. Благодаря устойчивости к высушиванию, материал удобно хранить и транспортировать. Также был предложен способ эффективной утилизации отработанного материала в виде удобрения для растений. 


\section{Сравнительный анализ ансамбля транспозонов некоторых геномов}

Мутовина О.А.

ИФБиБТ, 3 курс, Сибирский Федеральный Университет, кафедра биофизики, Красноярск, Россия

Ключевые слова: порядок, филогения, эволюция, покрытосеменные, голосеменные

Транспозонами называют участки генетической последовательности, способные самостоятельно перемещаться и размножаться внутри генома. К настоящему времени транспозоны обнаружены в геномах практически всех организмов, самого разного таксономического положения. Эти элементы генома являются весьма высоко частотными: они встречаются в большом числе копий, и само разнообразие транспозонов тоже велико. Однако обнаружение и изучение транспозонов в геномах хлоропластов растений проведено еще недостаточно. Более того, многие авторы утверждают отсутствие транспозонов в этих генетических системах.

Было проанализировано 100 геномов хлоропластов наземных растений из следующих семейств: Злаки, Бобовые, Кленовые, Жимолостные, Мальвовые, Мориновые, Маслиновые, Амарантовые, Астровые, Барбарисовые, Лютиковые, Пасленовые, Хризобалановые, Никтагиновые, Сосновые и Кипарисовые.

Основной задачей исследования был поиск и анализ транспозонов в этих геномах. Анализируемые геномы были взяты из базы NCBI. Поиск транспозонов осуществлялся программой Censor. B исследованных геномах хлоропластов наземных растений были обнаружены транспозоны. При этом поиск транспозонов осуществлялся по образцу: для поиска последовательности транспозона используется библиотека Repbase. Условиями поиска является выбор источника последовательности и активация опции поиска идентичных или почти идентичных фрагментов. Установлено, что в проанализированных геномах содержатся 4 различных транспозона; число копий отдельных транспозонов варьировало от 1 до 200.

Проанализирован состав транспозонов, встречающихся в различных геномах, по их структуре и близости друг к другу. 
DOI 10.18699/SBB-2020-77

\section{Биоразнообразие эндофитов винограда Vitis amurensis Rupr.}

Нитяговский Н.Н.*, Киселев К.В., Алейнова О.А.

ФГБУН «Федеральный научный иеентр биоразнообразия наземной биоть Восточной Азии» ДВО РАН, Владивосток,

Россия

*e-mail: niknit1996@gmail.com

Ключевые слова: эндофиты, бактерии, грибы, Vitis amurensis

Мотивация и цель: В последнее время исследователи стали уделять большое внимание изучению эндофитов различных растений. Практический интерес к эндофитам связан, в первую очередь, с оценкой возможности их использования в производстве биопрепаратов для повышения продуктивности культурных растений, защиты их от фитопатогенной микрофлоры и повышения качества урожая $[1,2]$. В настоящее время есть работы, посвященные исследованию эндофитов Vitis vinifera, но нет никаких данных об изучении свойств природных изолятов эндофитных бактерий и грибов, ассоциированных с тканями винограда $V$. amurensis. Известно, что данный вид хорошо переносит низкие температуры и имеет относительно высокую сопротивляемость к патогенам.

Meтоды и алгоритмы: В данной работе было проанализировано разнообразие эндофитных бактерий и грибов двух растений винограда $V$. amurensis, произрастающих на территории пригорода г. Владивостока, в летний и осенний периоды 2018-2019 гг. Из поверхностно стерилизованных листьев, стеблей и ягод $V$. amurensis было выделено 420 изолятов эндофитных бактерий и 53 изолята грибов. Далее в полученных изолятах были секвенированы участки гена $16 \mathrm{~S}$ pРНК (бактерии) или ITS (грибы). Используя программу BLASTN, по данным секвенирования изоляты винограда были определены до рода.

Результаты: Сообщество эндофитов $V$. amurensis было представлено 31 родом эндофитных бактерий и 23 родами грибов. Среди эндофитных бактерий наибольшее число изолятов было представлено родами Erwinia, Pantoea и Pseudomonas, а среди грибов-Cladosporium, Didymella и Colletotrichum.

Заключение: Населяющие растение винограда V. amurensis эндофиты являются интересными для дальнейшего изучения их свойств, что в будущем может привести к созданию биотехнологических препаратов, применяемых в различных сферах жизни человека. Результаты исследования доступны по ссылке: https://docs.google.com/spreadsheets/d/1qhhYXgD3NhszC0iPhu8wikWpmFmGS5ZdmkiU7gkElVk/edit?usp=sharing Благодарности: Работа выполнена при финансировании гранта РНФ № 20-74-00002.

Список литературы

1. Ryan R.P. et al. Bacterial endophytes: recent developments and applications. FEMS Microbiol Letters. 2008;278(1):1-9.

2. Lugtenberg B.J.J. et al. Fungal endophytes for sustainable crop production. FEMS Microbiol Ecol. 2016;92(12):fiw194. 


\title{
Распознавание генотипа колоса пшеницы методами Computer Vision
}

\author{
Паулиш А. ${ }^{1 *}$, Пронозин А. ${ }^{2}$, Комышев Е. ${ }^{2}$, Генаев M. ${ }^{1,2}$ \\ ${ }^{1}$ Новосибирский государственный университет, Новосибирск, Россия \\ ${ }^{2}$ Институт циттологии и генетики СО РАН, Новосибирск, Россия \\ *e-mail: apaulish99@gmail.com
}

Ключевые слова: обработка изображений, машинное обучение, биотехнологии, искусственный интеллект

Мотивация и иеель: Для генетики пшеницы важной задачей является определение плоидности. Классический подход решения этой задачи основан на использовании молекулярно-генетических методов, которые дороги и трудозатратны. Поэтому в данной работе мы проверяем гипотезу: возможно ли определить плоидность пшеницы, используя методы компьютерного зрения, только лишь на основании цифрового изображения колоса.

Meтоды и алгоритмы: Первый подход, который мы использовали для решения поставленной задачи основан на существующем алгоритме, позволяющем из каждого изображения извлечь фиксированный набор различных количественных признаков. Подробное описание алгоритма есть в статье [1]. Используя данный алгоритм, нами были обучены три модели для предсказания типов плоидности, основанные на методах логистической регрессии, случайном лесе и градиентом бустинге. Второй подход предсказания плоидности основан на классификации изображений с помощью сверточной нейронной сети. Мы использовали сеть архитектуры EfficientNet B0 [2] с предобученными на ImageNet [3] весами. В качестве меры точности мы использовали метрику AUC. Результаты: Нами было показано, что большая плоидность, дает более вариабельные значения признаков. Для гексаплоидов характерна больший разброс/дисперсия значений признака. Это происходит потому, что число копий генов у гексаплоидов больше. И поэтому увеличивается число вариантов «работы» этих генов. При оценке качества предложенных моделей лучший результат показала модель, основанная на сверточной нейронной сети, точность которой на отложенной выборке AUC $=0.995$, что соответствует ошибке $1.3 \%$.

Заключение: Разработанная модель интегрирована в веб сервис (ссылка: https://spikecvdemo.sysbio.ru). Наш вклад в данный сервис состоит в том, что по входному изображению (которое загружает пользователь) предсказывается его плоидность.

\section{Список литературь}

1. Genaev et al. Morphometry of the Wheat Spike by Analyzing 2D Images, 2019.

2. Tan M., Le Q.V. Efficientnet: Rethinking model scaling for convolutional neural networks. arXiv preprint arXiv:1905.11946. 2019.

3. Deng J. et al. Imagenet: A large-scale hierarchical image database. 2009 IEEE conference on computer vision and pattern recognition. IEEE. 2009. P. 248-255. 
DOI 10.18699/SBB-2020-79

\title{
Генетическое сходство Gyrodactylus sphinx (Platyhelminthes: Monogenea) \\ из Черного моря с новым подродом морских видов, обитающих в юго-восточной части Тихого океана, а также в Средиземном и Северном морях
}

\author{
Прохорова Д.А., Дмитриева Е.В., Водясова Е.А. \\ Институт биологии южных морей им. А.О. Ковалевского, Севастополь, Россия
}

Ключевые слова: Gyrodactylus, генетическая изменчивость, Черное море

Моногенеи рода Gyrodactylus von Nordmann, 1832 известны уже почти 200 лет и являются интересными объектами благодаря своему необычному циклу размножения и высокой скорости дивергенции. Представители данного рода распространены практически повсеместно, однако история их расселения и процессы видообразования до сих пор являются предметом дискуссий. Черноморский регион является молодым бассейном с хорошо изученной палеогеографией. Существующая изоляция от Средиземноморья за счет систем проливов Босфор и Дарданеллы, достаточно хорошая изученность видов рыб и время их проникновения в Черное море делает данный регион интересным с точки зрения анализа возможной генетической дивергенции и изучения процессов видообразования рода Gyrodactylus.

В качестве молекулярного маркера был выбран ядерный регион ДНК рибосомального кластера, включающий ITS1, 5.8S, ITS2. Данный маркер является достаточным для того, чтобы говорить о видовой принадлежности, в силу своей консервативности внутри вида.

Проведенный филогенетический анализ показал, что монофилетическая клада Gyrodactylus sphinx сгруппировалась с двумя другими кладами, включая G. orecchiae, G. chileani, G. proterorhini и G. cf. niger, которые ранее были признаны новой группой морских видов, предки которых, вероятно, пересекли экватор. Кроме того, морфология G. sphinx весьма схожа с G. chileani, и оба вида поражают прибрежных морских рыб подотряда Blennioidei. Это говорит об их возможном родстве, несмотря на очень удаленный ареал распространения этих видов.

Благодарности: Работа выполнена в рамках тем № AАAА-А19-119060690014-5 и № AAАA-A18118020890074-2 государственного задания ФИЦ ИнБЮМ.

Список литературы

1. Ziętara MS, Huyse T, Lumme J \& Volckaert FA. 2002. Deep divergence among subgenera of Gyrodactylus inferred from rDNA ITS region. Parasitol. 124:39-52.

2. Ziętara MS, Lebedeva D, Muñoz G \& Lumme J. 2012. A monogenean fish parasite, Gyrodactylus chileani n. sp., belonging to a novel marine species lineage found in the South-Eastern Pacific and the Mediterranean and North Seas. Systematic Parasitol. 83:59-67. 


\title{
Разработка и апробация хлоропластных праймеров для анализа гаплотипов хурмы коллекции ФИЦ СНЦ РАН
}

\author{
Рахмангулов Р.С.*, Симонян Т.А., Мацькив А.О., Цатурян Г.А., Шуркина Е.С., Омаров М.Д., \\ Кулян Р.В., Омарова 3.М. \\ Федеральное государственное бюджетное учреждение науки «Федеральный исследовательский центр \\ «Субтропический научный иентр Российской академии наук»», Россия \\ *e-mail: rakhmaruslan@yandex.ru
}

Ключевые слова: хлоропластные праймеры, Diospyros kaki, D. lotus, D. virginiana

Цель: Хурма является перспективной субтропической культурой для возделывания на Юге России. Несмотря на многочисленные молекулярно-генетические работы зарубежных исследователей, генетическое разнообразие и филогенетические взаимосвязи российской коллекции сортов хурмы до сих пор не изучены.

Meтоды: Объектами исследования послужили генотипы хурмы из коллекций ФИЦ СНЦ РАН, среди которых сорта Diospyros kaki, виды хурмы D. lotus и D. virginiana. ДНК выделяли из вызревших листьев хурмы методом ЦТАБ [1]. Анализировали качество выделенной ДНК с помощью электрофореза в 1,5\% агарозном геле; концентрацию ДНК измеряли на спектрофотометре BioDrop microlite. Анализ генетического разнообразия хурмы проводили с помощью 9 хлоропластные маркеров на основе секвенированного хлоропластного генома [2]. Объем реакционной смеси 25 мкл, из которых 12,5 мкл двухкратный ПЦР буфер (Биолабмикс) содержащий Таq-ДНК-полимеразу горячего старта. ПЦР смесь содержала 0.5 мкл маркера (10 мкмоль), 1 мкл ДНК ( 66,6 мкг/мл) и деионизированную воду. Амплификацию проводили по следующей программе: преинкубация 5 мин при $95{ }^{\circ} \mathrm{C}$, денатурация 15 сек при $95{ }^{\circ} \mathrm{C}$, отжиг 40 циклов по 40 сек при $60{ }^{\circ} \mathrm{C}$, с последующей финальной элонгацией 5 мин при $72{ }^{\circ} \mathrm{C}$. Продукты ПЦР визуализировали в $1.5 \%$ агарозном геле с $1 \times \mathrm{TAE}$ буфером при напряжении $90 \mathrm{~V}$. Анализ генетических дистанций проводили методом Neighbor Joining c коэффициентами попарного сходства по L.R. Dice [3]. Построение дендрограммы филогенетических дистанций исследуемых сортов хурмы проводилось с помощью пакета программ Darwin.

Pезультаты: На основе секвенированного хлоропластного генома, было разработано 9 хлоропластных маркеров. Из разработанных 9 маркеров 4 разработаны на основе, D. lotus и 5 на основе D. kaki. К этим маркерам были разработаны праймеры с температурой отжига не менее $60{ }^{\circ} \mathrm{C}$ и соотношением GC пар в соотношении 47-53\%. С помощью данных праймеров были получены амплифицированные фрагменты размером 176-250 пн. Разработанные праймеры показали высокую эффективность для выявления различий между образцами хурмы в коллекции ФИЦ СНЦ РАН.

Заключение: В результате хлоропластного анализа выявлено три основных гаплотипа, из которых один уникальный гаплотип. Эти данные послужат основой для целенаправленной селекции хурмы и увеличения генетического разнообразия коллекций хурмы.

\section{Список литературы}

1. Doyle J.J., Doyle J.L. A rapid DNA isolation procedure for small quantities of fresh leaf tissue. Phytochemical Bulletin, 1987;19:11-15.

2. Fu J., Liu H., Hu J., Liang Y., Liang J., Wuyun T., Xioafeng T. Five complete chloroplast genome sequences from Diospyros: genome organization and comparative analysis. PlosOne. 2016.11(7): e0159566.doi:10.1371/journal.pone.0159566.

3. Dice L.R. Measures of the amount of ecologic association between species. Ecol. 1945;.26:297302.dx.doi.org/10.2307/1932409. 
DOI 10.18699/SBB-2020-81

\title{
Сравнительный транскриптомный анализ в динамике развития протеинопатии на мышиной модели бокового амиотрофического склероза FUS(1-359)
}

\author{
Резвых А. ${ }^{1,2 *}$, Устюгов А.А. ${ }^{3}$, Морозов А.В. ${ }^{1}$, Евгеньев М.Б. ${ }^{1}$, Фуников С.Ю. ${ }^{1}$ \\ ${ }^{1}$ Институт молекулярной биологии им. Энгельгардта РАН, Москва, Россия \\ ${ }^{2}$ Московский физико-технический университет, Долгопрудныгй, Россия \\ ${ }^{3}$ Институт физиологически активных веществ РАН, Черноголовка, Россия \\ *e-mail: aprezvykh@yandex.ru
}

Ключевые слова: боковой амиотрофический склероз, протеинопатия, RNA-seq

Цель работы: Боковой амиотрофический склероз (БАС) - тяжелое нейродегенеративное заболевание, при котором происходит необратимая гибель моторных нейронов, приводящая к прогрессирующему параличу и неминуемой смерти пациента. Фокус последних исследований направлен на изучение РНК-связывающих белков, таких как FUS и TDP43, мутации в которых приводят к агрегации белков, а также нарушению РНК-метаболизма. При этом неясно, какой из данных механизмов играет первичную роль в развитии патологического процесса. Для ответа на этот вопрос, мы провели сравнительный анализ экспрессии генов в динамике развития протеинопатии у трансгенной мышиной модели FUS(1-359).

Memoдbl: Дифференциальную экспрессию и альтернативный сплайсинг анализировали при помощи секвенирования мРНК тканей спинного мозга с помощью секвенатора Illumina NextSeq 500, с последующей биоинформатической обработкой данных. Агрегацию белков выявляли с помощью метода иммуногистохимии, визуализировали методом конфокальной микроскопии, нарушение двигательной активности анализировали с использованием системы регистрации походки Noldus Catwalk XT.

Результаты: Ранние проявления протеинопатии, детектируемые в единичных нейронах у мышей в возрасте 90 дней, протекают бессимптомно и сопровождаются изменениями в альтернативном сплайсинге, заключавшимися прежде всего в удержании интронов в транскриптах мотонейронов спинного мозга. Однако уже через месяц протеинопатия лавинообразно нарастала, приводя к масштабным изменениям в транскриптомном профиле клеток спинного мозга. Данные изменения выражаются в активации провоспалительного фенотипа микроглии и нарушение функции ацетилхолиновых синапсов в мотонейронах.

$B b l в o \partial b l$ : Изменения транскриптомного профиля в тканях спинного мозга при FUS-опосредованной протеинопатии, начинающиеся на пресимптоматической стадии и приобретают лавинообразный характер уже через 1 месяц, что приводит к массивной гибели мотонейронов спинного мозга и смерти мышей. Дальнейшие исследования систем клеточной адаптации, например, убиквитинпротеасомной системы позволят расширить наши представления о БАС и изучить возможность таргетной терапии этого заболевания.

Благодарности: Работа поддержана грантом Президента РФ МК-3316.2019.4 и грантом РФФИ № 20-34-90028. 
DOI 10.18699/SBB-2020-82

\section{Количественная оценка концентрации хлорофилла $a$ фототрофных микроорганизмов в воде с помощью методов машинного обучения и камеры мобильного телефона}

Руденко А.П.*, Теслюк А.Б., Мельникова А.А., Намсараев 3.Б.

НИЦ «Курчатовский институт», Москва, Россия

*e-mail: inasty5@mail.ru

Ключевые слова: хлорофилл, фототрофные микроорганизмы, качество воды, машинное обучение

Мотивация и цеель: Проблема массового развития микроорганизмов [1] в водоемах является крайне серьезной и может иметь негативное влияние на экологию и экономику любого региона (гибель обитателей водоема, выход из строя оборудования, снижение туристической привлекательности и т.д.). Кроме того, многие виды микроорганизмов токсичны, а значит вода, в которой концентрация микроорганизмов превышает норму, становится непригодной для использования человеком.

Meтоды $и$ алгоритмы: Основным показателем развития микроорганизмов в воде является концентрация пигментов, в частности, концентрация хлорофилла $a$ в воде. Существуют разные методы определения концентрации пигментов, например, спутниковые [2] или спектрофотометрические методы. Однако данные способы определения концентрации пигментов в пробах воды требуют наличия дорогостоящего оборудования и специалистов. В данной работе разрабатывается инновационное устройство для оценки концентрации хлорофилла $a$ и других пигментов фототрофных микроорганизмов с помощью камеры мобильного телефона и методов машинного обучения. Ключевыми преимуществами данного метода являются низкая себестоимость, простота и доступность технологии, а также мобильность устройства, что позволяет оперативно измерять концентрацию хлорофилла $a$ не отходя от водоема.

Результаты: На текущий момент сконструирован прототип устройства для определения концентрации хлорофилла $a$ в воде, проведены эксперименты с тестовыми культурами, разработана нейронная сеть для предсказания концентрации пигментов фототрофных микроорганизмов. Точность определения концентрации хлорофилла $a$ в ходе экспериментов составила $97 \%$.

Заключение и доступность: В ходе экспериментов было показано, что разрабатываемый метод применим для анализа концентрации хлорофилла $a$ в широком диапазоне значений.

Благодарности: При поддержке программы «УМНИК» Фонда Содействия Инновациям.

Список литературы

1. Namsaraev Z., Melnikova A., Komova A., Ivanov V., Rudenko A., Ivanov E. (2020) Algal Bloom Occurrence and Effects in Russia;12(1):285.

2. Namsaraev Z., Melnikova A., Ivanov V., Komova A., Teslyuk A. (2018) Cyanobacterial bloom in the world largest freshwater lake Baikal;121(3):32-39. 


\title{
Идентификация аллелей $\mathrm{S}$ гена самонесовместимости у сортов черешни
}

\author{
Смирнов Р.В. \\ Федеральный исследовательский иентр Всероссийский институт генетических ресурсов растений имени \\ Н.И. Вавилова, Санкт-Петербург, Россия \\ e-mail:smirnov_roman88@mail.ru
}

Ключевые слова: Prunus avium, S-локус, самобесплодность, самоплодность, ДНК-маркеры

Мотивация и цель: Самобесплодность черешни требует подбора для производственных садов перекрестно опыляемых сортов с одинаковыми сроками цветения и приводит к невозможности закладки насаждений моноблоками, является существенным минусом для производства (3). В работе проведен молекулярный скрининг сортов и гибридов из коллекции Крымской опытной селекционной станции - филиала ВИР с целью идентификации наиболее часто встречающихся у черешни аллелей $\mathrm{S}$ гена.

Meтоды и алгоритмы: В анализ включили 58 сортов черешни, кроме того, были проанализированы 49 гибридных генотипов. Использовано два независимых подхода: ПЦР с аллель-специфичными праймерами PaS1, PaS2, PaS3, PaS4, PaS5, PaS6, PaS7, PaS9, PaS10, PaS12, PaS13, PaS14, PaS16, и ПЦР с консенсусными праймерами PaConsI, PaConsII $(1,2)$.

Результаты: Проведенный молекулярный скрининг идентифицировал в коллекционном и селекционном материале Крымской ОСС наиболее часто встречающиеся у черешни аллели S3, S4 и S9. Был определен также ряд других аллелей присутствующих у образцов коллекции. В дальнейшем полученная информация об аллельном составе будет использоваться для подбора сортов опылителей и селекционной работы Данная работа позволила выявить генотипы - носители ассоциированной с признаком самоплодности аллели S4 (4). Показано, что выбранные нами для получения гибридов самоплодные сорта черешни в $64 \%$ случаях дают искомое потомство с аллелью S4; высокий процент получения таких гибридов отмечен при применении сорта Skeena, что дает возможность характеризовать его как донор самоплодности.

Заключение и доступность: Использование методов молекулярного маркирования позволяет на ранних этапах выявлять потенциально самофертильные формы и тем самым во много раз ускорять селекционный процесс.

\section{Список литературы}

1. Sharma K., Sedlák P., Zeka D., Vejl P., Soukup J. Allele-specific PCR detection of sweet cherry selfincompatibility alleles S3, S4 and S9 using consensus and allele-specific primers in the Czech Republic. Hort. Sci. 2014;41:153-159. https://doi.org/10.17221/89/2014-HORTSCI

2. Sonneveld T., Tobutt K.R., Robbins T.P. Allele-specific PCR detection of sweet cherry self-incompatibility (S) alleles S1 to S16 using consensus and allele-specific primers. Theor Appl Genet. 2003;107:1059-1070. DOI 10.1007/s00122003-1274-4

3. Супрун И.И., Токмаков С.В., Степанов И.В. Идентификация аллелей S2, S3, S5, S6 гена самонесовместимости у сортов черешни из коллекции СКЗНИИСиВ. Методологическое обеспечение селекции садовых культур и винограда на современном этапе. Краснодар. СКЗНИИСиВ. 2013;1:97-101.

4. Wiersma P., Wu Z., Zhou L., Hampson C., Kappel F. Identification of new self-incompatibility alleles in sweet cherry (Prunus avium L.) and clarification of incompatibility groups by PCR and sequencing analysis. Theor Appl Genet. 2001;102:700-708 DOI:10.1007/s001220051700 


\section{Особенности применения регуляторов роста в технологии производства саженцев яблони в условиях предгорной зоны садоводства}

Смирнов Р.В.

ФГБОУ ВО «Кубанский государственный аграрный университет имени И.Т. Трубилина», Краснодар, Россия e-mail: smirnov_roman88@mail.ru

Ключевые слова: яблоня, сорто-подвойные комбинации, регуляторы роста

Мотивация и цель: На данный момент рынок перенасыщен некачественным материалом. Некомпетентное отношение к процессу приводит к существенным материальным потерям во всей отрасли. Оптимизация производственных процессов в питомнике является весьма значимой на данный момент. Цель исследований - разработать инновационные элементы технологии производства высококачественного посадочного материала яблони в условиях предгорной зоны садоводства.

Meтоды u алгоритмы: Химические обработки проводились в конце июня при достижении растениями высоты 60 см [1]. Обработку препаратом «Эплин» проводили раствором препарата согласно рекомендации производителя 0,6 г/л. Обработку препаратом Д-6 проводили в двух различных концентрациях раствора 0,006 и 0,004 мг/л. Применение препаратов проводили в вечернее время обрабатывая участок центрального побега от высоты 40 см от земли до точки роста $[2,3]$. Определение влияния регуляторов роста Эпллин и Д-6 проводили методом учета биометрических показателей.

Pезультаmы: Применение регуляторов роста повысило количество боковых побегов сорта Чемпион на всех подвойных комбинациях. Так на подвое М 9 наибольшее количество разветвлений отмечалось в опыте с применением препарата Д-6 в концентрации 0,004 г/л, что выше контроля на 53\%. На подвоях ММ 106 и ПБ 9 этот же препарат, но уже в большей концентрации $(0,006$ г/л) также оказал воздействие на образование боковых ответвлений в сравнении с контролем на 44,4 и 75\% соответственно. Стоит также отметить влияние препарата Д-6 на прирост диаметра штамба в комбинации Чемпион/ ПБ 9. В комбинации Ренет Симиренко/ М 9 применение препарата Д-6 в концентрации 0,006 показатель превышал контроль на 36,8\%. В комбинации Ренет Симиренко/ ПБ 9 обе концентрации этого препарата дали одинаковые результаты по сравнению с контролем. Лучший результат по количеству разветвлений был получен при обработке регулятором роста Эплин сорт подвойной комбинации Голд Раш/ M 9 и Голд Раш/ ПБ 9 с применением регулятора роста Д-6 в концентрации 0,004 г/л, разница с контролем составила 66,6. Применение препарата Д6 в концентрации 0,006 показало наилучшие результаты в сорто-подвойных комбинациях Пинк Леди/ ММ 106 и Пинк Леди/ ПБ 9, разница с контролем составила 69 и 60 соответственно.

Заключение и доступность: Для увеличения количества вегетативных разветвлений и генеративных почек рекомендуется применять регулятор роста Д-6 в концентрации 0,004 г/л.

\section{Список литературы}

1. Барабаш И.П. Фитогормоны. Регуляторы роста (классификация, теория, практика). Ставрополь, 2009.

2. Барабаш И.П. Фитогормоны (эндогенные регуляторы) растении. Садоводство и виноградарство. 2008. № 4. C. $22-23$.

3. Чернов А. И. Способы формирования крон у однолетних саженцев. Научный журнал КубГАУ. 2014. № 98. URL: https://cyberleninka.ru/article/n/sposoby-formirovaniya-kron-u-odnoletnih-sazhentsev. 


\section{Иммуногенетические предикторы раннего прерывания беременности}

Татаркова Е.*, Тугуз А., Шумилов Д.

Адыгейский государственный университет, НИИ Комплексных проблем, Майкоп, Россия

*e-mail:warmwild@yandex.ru

Ключевые слова: цитокины, SNP, SLC19A1, IL-1 $\beta$, TNF- $\alpha$, IL-12B

Мотивация и иель: Высокая смертность и социально-экономический ущерб от репродуктивных потерь в Российской Федерации обусловливает необходимость выявления молекулярногенетических маркеров, вовлеченных в патогенез угрозы выкидыша $[1,2]$. В связи с этим работа направлена на установление полиморфизмов генов-маркеров, ассоциированных с развитием угрозы выкидыша в I триместре беременности для жительниц Республики Адыгея (РА).

Meтоды и алгоритмы: В обследованной группе 58 жительниц РА $(28,5 \pm 5,7$ года) с диагнозом угрозы прерывания беременности в срок до 13 нед.; в контроле - здоровые женщины $(n=51$; $28,4 \pm 5,97$ года). Использованы методы: ПЦР с электрофоретической детекцией результатов (НПФ «Литех», Россия) и в режиме Real-Time («Генетика метаболизма фолатов», ООО «ДНКтехнология», Россия); ИФА с использованием коммерческих тест-систем ООО «Цитокин» (СанктПетербург, Россия). МНК выделены по методу А. Воуum (1968). Статистические расчеты проведены с использованием пакета прикладных программ SPSS Statistics 17.0 (Inc., Chicago, USA) и Office Excel 2016 (Microsoft).

Результаты: С угрозой раннего прерывания беременности у жительниц РА ассоциированы: гетерозиготный генотип G80A гена транспортера фолатов SLC19A1 (OR $=4,11 ; 95 \%$ CI = 1,39$12,18 ; \mathrm{p}=0,02)$, «мутантная» -511Т аллель гена медиатора острого воспаления IL-1 $\beta(\chi 2=16,96 ; \mathrm{p}=$ $0,00004 ; \mathrm{OR}=5,8)$, гетерозиготный C511T и гомозиготный T511T генотипы гена IL-1 $\beta$, повышающие риск осложнения беременности в первом триместре соответственно в 3,5 и 5,7 раз ( $\chi 2$ $=14,81 ; \mathrm{p}=0,0006)$, а также $-1188 \mathrm{C}$ аллельный вариант гена регуляторного IL-12B $(\chi 2=6,17 ; \mathrm{p}=$ $0,01 ; \mathrm{OR}=2,97)$. Гетерозиготный генотип C511T промоторного региона гена острого воспаления IL-1 $\beta(\mathrm{p}=0,032)$ и гомозиготный «нормальный» генотип G308G плейотропного цитокина TNF- $\alpha$ (p $=0,045)$ определяют уровни продукции и соотношение медиаторов воспаления, участвующих в формировании фетоплацентарного комплекса, и являются генетическими предикторами угрозы ранних гравидарных потерь.

Заключение и доступность: Генетически детерминированная оверэкспрессия IL-1 $\beta$ и снижение продукции TNF- $\alpha$, выявленные в экспериментах in vitro при оценке стимулированной продукции цитокинов МНК в группе женщин с угрозой раннего прерывания беременности, подтверждают ведущую роль медиаторов воспаления «первой волны» в патогенезе репродуктивных осложнений.

Список литературы

1. Гордеева Л.А. и др. Ассоциации полиморфизма генов цитокинов с невынашиванием беременности. Медищинская иммунология. 2017;19(5):585-596.

2. Николаева А.Е. и др. Ретрохориальная гематома как фактор риска возникновения гематологических осложнений беременности. Вестник гематологии. 2018;XIV(1):22-27. 
DOI 10.18699/SBB-2020-86

\section{Проект создания геномно-географического атласа автохтонных сортов винограда России}

Федосов Д.Ю.

НИЦ «Курчатовский институт», Москва, Россия

e-mail: Fedosov_DY@nrcki.ru

Ключевые слова: виноград, геном, автохтонные сорта

Мотивация и иель: Несмотря на принадлежность к одному к виду, высокая степень генетического полиморфизма обуславливает огромное разнообразие сортов винограда Vitis vinifera. Первая сборка генома V. vinifera (сорт Пино нуар) была опубликована в 2007 году [1], подобные работы позволяют по-новому подходить к генотипированию и классификации сортов и их семейств. Так, анализ сборки бургундского сорта Шардоне показал, что размер его генома превышает размер генома близкородственного сорта Пино нуар более чем на 20\% [2]. Это подчеркивает необходимость получения независимых геномных сборок сортов более чем 140 российских автохтонных сортов винограда.

Meтоды и алгоритмы: Планируется получить высококачественные геномные сборки ключевых автохтонных российских сортов винограда, которые будут использоваться как референсные при генотипировании других. Планируется использовать гибридную сборку, полученную комбинированием технологий высокопараллельного секвенирования - одномолекулярного секвенирования Oxford Nanopore и технологий коротких прочтений (BGI и/или Illumina). Это позволит с высокой точностью оценить как однонуклеотидные полиморфизмы, так и крупные структурные перестройки. В реализации стратегии планируется задействовать наработки по генотипированию автохтонных сортов специалистов ФГБУН «ВННИИВиВ «Магарач» РАН» (Ялта) и СКЗНИИСВиВ (Краснодар).

Результаты: В течение 2020 года будут получены высококачественные геномные сборки сортов Красностоп золотовский и Кокур белый. Дальнейшие этапы включают геномную идентификацию, отделение возможных повторов и клонов, секвенирование других сортов.

Заключение u доступность: При помощи биоинформатического анализа нуклеотидных полиморфизмов и анализа сегментов, идентичных по происхождению (identity-by-descent), будет построена карта филогенеза автохтонных российских сортов, выявлены ключевые группы, генетически детерминированы ведущие сортовые признаки. Планируемый геномногеографический атлас будет включать данные метаболомики сортов, истории, географии, ампелографии и энологии.

Благодарности: Работа выполняется на основании Соглашения с Минобрнауки РФ № 075-15-20191659 от 31.10.2019.

\section{Список литературы}

1. Velasco R. et al. A high quality draft consensus sequence of the genome of a heterozygous grapevine variety. PLoS ONE. 2: e1326 (2007).

2. Zhou et al. The population genetics of structural variants in grapevine domestication. Nature Plants. V. 5, P. $965-979$ (2019). 


\title{
Распределение генов митохондрий грибов в пространстве частот триплетов
}

\author{
Федотовская В.Д. ${ }^{*}$, Шпагина Т.О. ${ }^{1}$, Колесникова А.И. ${ }^{1}$, Садовский М.Г. ${ }^{1,2}$ \\ ${ }^{1}$ Сибирский федеральный университет, Институт фундаментальной биологии и биотехнологии, Красноярск, Россия \\ ${ }^{2}$ Институт вычислительного моделирования СО РАН, Красноярск, Россия \\ *e-mail: viktoriia.fedotovskaia@gmail.com
}

Ключевые слова: структура, функция, нуклеотидные последовательности, упругие карты, метод динамических ядер, митохондриальные геномы грибов

Мотивация и цель: Выявление связи между структурой нуклеотидной последовательности, функцией, кодируемой ей, и таксономией ее носителя - одна из фундаментальных задач биоинформатики. Такие исследования зависят от выбранного материала. Ранее указанная связь исследовалась на геномах хролопластов [1] и на последовательности РНК генов бактерий [2].

Meтоды и алгоритмы: В данной работе связь между структурой, функцией и таксономией изучалась на примере трех генов митохондрий грибов (atp6, atp8 и atp9) пяти таксономических единиц - отделов. Из полных митохондриальных геномов были выделены указанные гены в двух версиях: исходные последовательности с интронами и последовательности без интронов. Каждая версия преобразовывалась в частотный словарь триплетов с единичным или тройным шагом рамки считывания. Далее на упругих картах рассматривалось распределение генов в 64-мерном пространстве, где осями являлись частоты триплетов. Кроме того, была проведена кластеризация генов методом динамических ядер. Словари разбивались на кластеры для $2 \leq \mathrm{K} \leq 5$, результат кластеризации проверялся на устойчивость.

Результаты: Распределение генов на упругой карте оказалось упорядоченным - выделялись кластеры, точки в которых соответствуют одинаковым генам. Связи с таксономией найдено не было. Результаты кластеризации методом динамических ядер были представлены в виде слоистого графа, где было показано перераспределение генов при увеличении числа кластеров. В этом случае также выделялись геноспецифичные кластеры, не было найдено связи с таксономией.

Заключение и доступность: Таким образом, при использовании двух методов кластеризации (линейного и нелинейного) на примере геномов митохондрий грибов было доказано преобладание функции над таксономией. Данный генетический материал является специфичным, поэтому мы не можем утверждать, что обнаруженный эффект универсален.

\section{Список литературы}

1. M. Sadovsky et al. Genome structure of organelles strongly relates to taxonomy of bearers. Bioinformatics Biomedical Engineering. 2015:481-490.

2. Горбань А.Н. Классификация нуклеотидных последовательнстей по частотным словарям обнаруживает связь между их структурой и таксономическим положением организмов. Журнал общей биологии. 2003:64(1):65-77. 


\title{
Видовая идентификация энтомопатогенного гриба с помощью молекулярно- генетического анализа
}

\author{
Чемезова А.А. ${ }^{*}$, Майкова О.О. ${ }^{2}$ \\ ${ }^{1}$ Средняя общеобразовательная школа № 24, Иркутск, Россия \\ 2 Лимнологический институт СО РАН, Иркутск, Россия \\ *e-mail: chemezova_2006@mail.ru
}

Ключевые слова: энтомопатогенные грибы, молекулярно-генетический анализ, Beauveria bassiana

Мотивация и цель: Грибы, поражающие насекомых, называются энтомопатогенными и являются природными регуляторами численности «вредных» видов насекомых. Для данной работы энтомопатогенный гриб был получен из имаго сибирского шелкопряда, собранного с хвойных деревьев на территории Иркутской области. Цель работы - определить вид энтомопатогенного гриба с помощью молекулярно-генетического анализа.

Meтоды и алгоритмы: Для проведения секвенирования по Сэнгеру были проведены следующие основные этапы: 1) выделение ДНК из материала; 2) подбор и заказ праймеров; 3) проведение полимеразной цепной реакции (ПЦР); 4) проведение гель-электрофореза для разделения фрагментов ДНК; 5) проведение секвенирования (образцы были отправлены в компанию «Синтол», г. Москва). 6) анализ данных и построение филогенетического дерева.

Более подробно хотели бы остановиться на двух этапах: подбор праймеров и анализ данных полученных после секвенирования.

Подбор праймера осуществляли двумя методами:

1. Выбор праймеров по литературным источникам [1]: Пара праймеров на ген фактора элонгации EF-1 $\alpha$

5' GCT CCC GGT CAC CTG AYTTYA T 3'

5' ATG ACA CCG ACA GGA CGG TCT G 3'
2. Разработка праймера с использованием Genbank (Primer-BLAST) Пара праймеров $18 \mathrm{~S}$ pPHК

NS1 GTAGTCATATGCTTGTCTC NS6 GCATCACAGACCTGTTATTGCCTC

Pезультаты: Результаты секвенирования получены в виде файлов с расширением *.ab1. Длина амплифицированного фрагмента гена EF-1 $\alpha$ рРНК составила 930 п.н. С помощью программы Bioedit мы визуализировали данные и провели поиск в базе данных GenBank используя Nucleotide BLAST, в результате чего показали наибольшую гомологию (100\%) с видом Beauveria bassiana. Построено филогенетическое дерево байесовским методом с использованием программы MrBayes и визуализировано с помощью программы FigTree. На построенном филогенетическом дереве анализируемая последовательность кластеризуется с последовательностью вида Beauveria bassiana. $B b l в o d b l:$ Для повышения точности результатов при минимальном количестве прочтений и короткой длины чтения, необходима ручная обработка ридов и сборка части генома. Молекулярногенетическими методами показано, что вид искомого гриба с вероятностью $100 \%$ относится $\kappa$ Beauveria bassiana.

\section{Список литературы}

1. Крюков В.Ю. Адаптация энтомопатогенных аскомицетов (Ascomycota, Hypocreles) к насекомым-хозяевам и факторам среды в условиях континентального климата Западной Сибири и Казахстана: дис. док. биол. наук: 03.02.08. Новосибирск, 2014. 249 с. 
DOI 10.18699/SBB-2020-89

\title{
Ассоциация G1181C полиморфизма гена TNFRS11B с риском развития ишемической болезни сердца у жителей Республики Адыгея
}

\author{
Шумилов Д.*, Тугуз А., Татаркова Е. \\ Адыгейский государственный университет, НИИ Комплексных проблем, Майкоп, Россия \\ *e-mail:dmi6277@yandex.ru
}

Ключевые слова: атеросклероз, ишемическая болезнь сердца, фактор некроза опухоли

Мотивация и цель: По оценкам ВОЗ, основными причинами смертности и инвалидизации населения мира являются болезни системы кровообращения. При этом ежегодные потери от ишемической болезни сердца, развившейся на фоне атеросклеротического поражения коронарных сосудов, составляют более 7 миллионов человек. В России сохраняется самый высокий среди европейских стран уровень преждевременной смертности от ИБС, при этом само заболевание занимает главенствующую позицию. В мировых популяциях определение риска развития ИБС связывают с SNP в гене рецептора TNF-a. TNF-a - представитель семейства провоспалительных цитокинов с широким спектром активности. TNF связывается с двумя рецепторами, TNFR1 TNFR2, которые являются ключевыми медиаторами передачи сигналов от TNF.

Meтоды и алгоритмы: В исследование включен 61 житель республики Адыгея; в том числе: неродственные здоровые доноры $(n=16)$ и больные $(n=41)$ - пациенты кардиологического отделения Адыгейской республиканской клинической больницы (АРКБ) с диагнозом ИБС, подтвержденным инструментальными методами. Соответствие распределений SNP в обследованных группах больных и доноров проводили с использованием критерия $\chi 2$ (хи-квадрата) для таблиц сопряженности $2 \times 2$ с поправкой Йейтса на непрерывность, расчетом отношения шансов (Odds-Ration, или OR), 95\% доверительного интервала (95\% ДИ) и достоверности различий при $\mathrm{P} \leq 0,05$. Статистические расчеты проведены с использованием пакета прикладных программ SPSS Statistics 17.0 (Inc., Chicago, USA) и Office Excel 2016 (Microsoft).

Результаты: В ходе генетического анализа экспериментально установлено, что у жителей РА, носителей патологического C1181C генотипа и C1181 мутантной аллели риск развития ишемической болезни сердца повышается в 8 раз $(\chi 2=22,98 ; p<0,001 ; \mathrm{OR}=8)$.

Заключение и доступность: У жителей РА, с ИБС ассоциирован C1181C патологический генотип и $1181 C$ мутантная аллель гена TNFRSF11B $(\chi 2=22,98 ; \mathrm{p}<0,001)$.

Список литературь

1. Wang, M. et al. TNFRSF11B polymorphisms predict poor outcome after large artery atherosclerosis stroke. Gene. 2020. C. 144617.

2. Tong X. et al. Suppression of AMP-activated protein kinase reverses osteoprotegerin-induced inhibition of osteoclast differentiation by reducing autophagy. Cell Proliferation. 2019. P. e12714.

3. Kosmopoulos M. et al. The Emerging Role of Bone Markers in Diagnosis and Risk Stratification of Patients With Coronary Artery Disease. Angiol. 2019. V. 70. №. 8. P. 690-700. 
Afanasenko O. 49

Afanaseva E. 20

Afonnikov D. 47

Akimkin V.G. 32

Alekseeva S.S. 18

Alemasova E.E. 43

Andreeva Yu.V. 18

Anisimova E.O. 19

Antonets K. $\quad 39$

Astakhova T. 20

Battulin N. 42, 52

Belokopytova I. 21

Belokopytova P. 22

Belousova E.A. 37

Belousova M. 39

Berezhnaya A.A. 23

Biryukov M. 24

Blokhina K.S. 19

Brailko V.A. 29

Bulanenko V.P. 32

Bulavin I. $\quad 25$

Burnyasheva A.O. 26

Chikacheva S. 20

Dmitriev A.A. $\quad 28,46,48$

Dolgikh V.A. 27

Dubrovskii Y.A. 53

Dvorianinova E.M. 28, 48

Elatskov Yu. 51

Elatskova A. $\quad 51$

Emirsaliiev A.O. 29

Evtushenko E.V. 30

Fishman D. 22

Fishman V. 22, 44, 52

Frolov A.A. $\quad 39,53$

Gatzkaya S.S. $\quad 30$

Genaev M. $\quad 47$

Gorbach D. $\quad 39$

Gridina M. $\quad 44$

Gvaramiya S. 31

Ihling C. $\quad 39$

Kabilov M.R. 56

Kadtsyn E. $\quad 55$

Kaptelova V.V. 32

Karpova A. 20

Katsnelson L. 36

Kezimana P. 46

Khabarova A. 52

Khlestkina E.K. 35, 40, 49-51

Khotskin N. 21

Kirov I. 31, 34

Kiseleva A.A. 23, 33

Kolganova E. $\quad 34$
Kolosova N.G. 26

Kondaurova E. 21

Korneenko E.V. 32

Krasnov G.S. 28, 46, 48

Krylova E. $\quad 35$

Kuchendorf C. 91

Kudryavtseva L.P. 28

Kulikova E. $\quad 21$

Kurgina T.A. 43

Kursanov A. $\quad 36$

Kutuzov M.M. 37, 43

Laktionov P. 41

Lapteva A.R. $\quad 38$

Lashina N. $\quad 49$

Lavrik O.I. $\quad 37,43$

Lazareva M.N. 38

Leonova I.N. $\quad 33$

Levitsky V.G. 27

Lobov A. $\quad 39$

Lomzov A.A. $\quad 56$

Lukasheva E. $\quad 39$

Malovichko Y. 39

Markhasin V.S. 36

Medvedev D. $\quad 57$

Medvedev K. $\quad 36$

Melnikova N.V. 28, 46, 48

Merkulov P. 31

Mikhailova A. 40

Mitrofanova I.V. 29

Morozova E. 41

Mozheiko E. 22

Muravenko O. 34

Muravyova A. 42

Naumenko K.N. 43

Naumenko V. 21

Nikonov N. 20

Nizhnikov A. $\quad 39$

Novakovskiy R.O. 28, 46, 48

Nuriddinov M. 22

Nurislamov A. 44

Omarov M. 31

Orlov M.A. $\quad 45$

Oschepkov D.Y. 27

Polushkina I.D. 54, 57

Povkhova L.V. $\quad 46,48$

Pronozin A. $\quad 47$

Pshenichnikova T.A. 33

Pushkova E.N. 28, 46, 48

Pyshnyi D.V. $\quad 56$

Romanovskaya E. 39

Rozanova I.

49

Rozhmina T.A. 28, 46

Rudnitskaya E.A. 26

Ryzhkova A. 52 
Salina E.A. 23, 33

Samoilov A.E. 32

Savostyanov A. 20

Semilet T.V. $\quad 50$

Shipulina O.Y. 32

Sibataev A.K. 18

Silantyeva M.M. 50

Sineoky S.P. $\quad 19,38$

Singh P. $\quad 41$

Smirnov A. $\quad 42$

Soboleva A.V. 53

Solovyova O. 36

Speranskaya A.S. 32

Stefanova N.A. 26

Stegniy V.N. 18

Strygina K. 35, 40, 51

Sukhanova M.V. 43

Tamozhnikov S. 20

Tarutina M.G. 19, 38

Taskina A. 44, 52

Tekhanovich G. 51

Tykhonov A.Yu. 45

Ustyantsev K. 24

Valdokhina A.V. 32

Valiev E. $\quad 22$

Vashurina N.V. 53

Vasilev R.A. $\quad 54$

Vasiliev R. $\quad 57$

Vasilyeva A. $\quad 36$

Vikulova N. $\quad 36$

Vokhtantsev I. 55

Wasserlauf I.E. 18

Zamoskovtseva A.A. 56

Zemlyanskaya E.V. 27

Zheltova A. 57

Агаханов M.M. 58

Алейнова О.А. 93

Алексеев А.А. 59

Алексеев Я.И. 64

Антонова О.Ю. 63

Афанасьева Е. $62,70,76$

Бабиченко Н.П. 60

Бахмутова Е. 61

Белоногов А. 62,70

Беренсен Ф.А. 63

Блинова С.А. 64

Богданова В.С. 65

Болбат А.В. 65

Болбат Н.Б. 65

Бондаренко Т.А. 66

Борисова Н. $\quad 62,70,76$

Бородулин А.В. 66

Борунова В.В. 66

Бочаркина Ю.В. 67

Браилко В.А. 68

Булавин И.В. 68
Васильев Г.В. 65

Васильев Р.А. 73

Вестерманн Б. 86

Васко В.А. 86

Вихорев А. 69

Водясова Е.А. 95

Володин В.А. 64

Володькина В. 72

Выскребцов А. 62,70

Галкина С. 72

Галкина С.А. 75

Генаев М. 77, 94

Герасимова С.В. 69, 74, 83, 84

Гладышева-Азгари М.В. 71

Гребенникова О.А. 68

Грин И.Р. 79

Гришина Т. 86

Давидьян А. 72

Династия Е. 86

Дмитриева Е.В. 95

Домблидес Е.А. 81

Домрачев Д.В. 83

Евгеньев М.Б. 97

Евтеева М.A. 73

Егорова А.А. 74

Желтова А.В. 90

Жукова А.А. 75

Заварзин Е. $\quad 76,77$

Зинц А. 86

Ибрагимова С.М. 74

Илинг К. 86

Ильницкая Е.Т. 64

Казанцев Ф.В. 78

Кайгородова И.А. 65, 89

Карлов Г.И. 67

Карпова А. $\quad 70$

Каххарова 3.И. 79

Киселев К.В. 93

Кладова О.А. $\quad 80$

Козарь Е.В. 81

Козлова Т.А. 82

Колесникова А.И. 103

Колосова Н.Г. 82

Колосовская Е.В. 69, 83, 84

Комиссаров А.С. 72, 75

Комова А. $\quad 61,91$

Комышев Е. $\quad$ 77, 94

Короткова А.М. 69, 83, 84

Кочетов А.В. 74, 83

Коэппель И. 74

Кувырченкова А.П. 85

Кузнецов Н.А. 80

Кузнецова А. 86

Кузьмин С.В. 63

Кукоева Т.В. 84

Кулян Р.В. $\quad 96$

Кумлен Й. $\quad 74,83$ 
Лахова Т.Н. 87

Лашин С.А. $\quad 78,87$

Луданный Р.И. 66

Майкова О.О. $\quad$ 88, 104

Макаркина М.В. 64

Матвеенко Е.Ю. 65, 89

Мацькив А.O. 96

Медведев Д.О. 90

Мельникова А.А. 91, 98

Милахина Н. 76

Митрофанова И.В. 68

Морозов А.В. 97

Морозов С.В. 83

Москалу А.Ф. 63

Мутовина О.А. 92

Мухин А.M. 87

Намсараев 3. 61, 91, 98

Нестеров М.А. 74

Никонов Н. $\quad 62,76$

Нитяговский Н.Н. 93

Носульчак В.А. 58

Омаров М.Д. 96

Омарова 3.М. 96

Ощепков Д.Ю. 87

Паулиш А. 94

Петрова К.О. 71

Пискунова Т.М. 63

Пожидаев В.М. 60

Попова В. 86

Приходько А. 77

Пронозин А. 94

Прохорова Д.А. 95

Прохошин Н. 77

Разумова О.В. 67

Рахмангулов Р.С. 96

Резвых А. $\quad 97$

Руденко А.П. 91, 98

Рудницкая Е.А. 82

Сабоиев И.А. 74

Савостьянов А. 62, 70, 76

Садовский М.Г. 103
Сайфитдинова А.Ф. 75

Салина Е.А. $\quad 74$

Сапрыгин А. 70

Симонян Т.А. 96

Смирнов Р.В. 99, 100

Солдатенко А.В. 81

Стефанова Н.А. 82

Странишевская Е.П. 64

Таможников С. $62,70,76$

Татаркова Е. 101, 105

Теслюк А.Б. 98

Тугуз А. 101,105

Ульянич П.С. 58

Устюгов А.А. 97

Ухатова Ю.В. 58

Федорова О.С. 80

Федосов Д.Ю. 102

Федотовская В.Д. 103

Фролов А. 86

Фуников С.Ю. 97

Хамаз С. $\quad 74$

Хертиг К. 74, 83

Хикель Ш. 74

Хлесткина Е.К. 69, 83, 84

Цатурян Г.А. 96

Чемезова А.А. 104

Черняк Е.И. 83

Чикачева C. $\quad 62,76$

Шварцев А.А. 64

Шмаков Н. 69

Шпагина Т.О. 103

Шумилина Ю. 86

Шумилов Д. 101, 105

Шуркина Е.C. 96

Яцишина Е.Б. 60 


\section{Contents}

A comparative analysis of the metaphase chromosomes of Aedes excrucians, Ae. behningi,

Ae. intudens and Ae. punctor mosquitoes species (Diptera: Culicidae) in Tomsk region.

Alekseeva S.S., Andreeva Yu.V., Wasserlauf I.E., Sibataev A.K., Stegniy V.N.

Comparative analysis of the efficiency of gene expression of bacterial D-lactate dehydrogenases

in yeast Schizosaccharomyces pombe. Anisimova E.O., Blokhina K.S., Tarutina M.G., Sineoky S.P.

Event related potentials (ERP) of the brain in the conditions of the stop-signal paradigm in humans during the period of adaptation to the sub-polar climate. Astakhova T., Tamozhnikov S., Karpova A., Afanaseva E., Nikonov N., Chikacheva S., Savostyanov A.

Influence of 5-HT $\mathrm{HA}_{\mathrm{A}}$ receptors overexpression in the hippocampus on behavior and the brain serotonin system of BTBR mice - the model of autism. Belokopytova I., Kondaurova E., Kulikova E., Khotskin N., Naumenko V.

3DPredictor: machine learning-based algorithm for prediction of 3D chromatin structure.

Belokopytova P., Nuriddinov M., Mozheiko E., Fishman D., Valiev E., Fishman V.

Characterization of two novel VRN-B3 alleles in common wheat. Berezhnaya A.A.,

Kiseleva A.A., Salina E.A.

LTR retrotransposons in green plants show multiple examples of convergent evolution. Biryukov M.,

Ustyantsev $K$.

Genetic analysis of some thyme cultivars grown at the Nikita Botanical gardens' collection plots.

Bulavin I.

Changes in expression of genes associated with neurogenesis during development of Alzheimer's disease signs in OXYS rats. Burnyasheva A.O., Rudnitskaya E.A., Stefanova N.A., Kolosova N.G.

Structural heterogeneity of the EIN3 binding site affects the characteristics of transcriptional response to ethylene in Arabidopsis. Dolgikh V.A., Levitsky V.G., Oschepkov D.Y., Zemlyanskaya E.V.

Genome assembly of Fusarium oxysporum $\mathrm{f}$. sp. lini using a combination of Oxford Nanopore and Illumina reads. Dvorianinova E.M., Novakovskiy R.O., Pushkova E.N., Kudryavtseva L.P., Rozhmina T.A., Krasnov G.S., Melnikova N.V., Dmitriev A.A.

Molecular characterisation of population level genetic diversity of several endemic species of Thymus L. (Lamiaceae) by using ISSR markers. Emirsaliiev A.O., Brailko V.A., Mitrofanova I.V.

Expression profile of CENH3 paralogs in different tissues of the rye-wheat amphiploids and their parents. Gatzkaya S.S., Evtushenko E.V.

Nanopore-based retrotranscriptome analysis and proteome screening of A. thaliana ddml mutant.

Gvaramiya S., Merkulov P., Omarov M., Kirov I.

Genetic variability among 28 genomes of SARS-CoV-2 collected in Moscow in the early spring 2020.

Kaptelova V.V., Samoilov A.E., Valdokhina A.V., Bulanenko V.P., Korneenko E.V., Shipulina O.Y.,

Akimkin V.G., Speranskaya A.S.

Novel candidate genes for grain texture in Russian wheat varieties. Kiseleva A.A., Leonova I.N.,

Pshenichnikova T.A., Salina E.A.

De novo identification and sequence assembly of high-copy tandem repeats in raw data Oxford

Nanopore plant DNA sequencing data. Kolganova E., Muravenko O., Kirov I. 
Structural organization of TFL1-like genes of cowpea (Vigna unguiculata (L.) Walp.).

Krylova E., Strygina K., Khlestkina E.

Cardiac mechanics, calcium overload and arrhythmogenesis. Kursanov A., Solovyova O.,

Katsnelson L., Medvedev K., Vasilyeva A., Vikulova N., Markhasin V.S.

Influence of poly(ADP-ribose)polymerases 1 and 2 on base excisional repair in the context

of nucleosomes. Kutuzov M.M., Belousova E.A., Lavrik O.I.

A novel highly effective of $\beta$-mannanase producer on base Ogataea haglerorum yeast.

Lazareva M.N., Lapteva A.R., Tarutina M.G., Sineoky S.P.

Dissecting the bases of Bacillus thuringiensis host specificity: genomic and proteomic approaches.

Malovichko Y., Gorbach D., Belousova M., Romanovskaya E., Lukasheva E., Lobov A., Ihling C.,

Frolov A., Nizhnikov A., Antonets K.

In silico analysis of the $R 2 R 3-M y b, b H L H-M y c$ and $W D R$ proathocyanidins regulatory genes

in Gossypium genus. Mikhailova A., Strygina K., Khlestkina E.K.

The role of LMNB1 protein in replicative senescence of primary human fibroblasts. Morozova E.,

Laktionov P., Singh P.

Creating the barcoded plasmid library to study the mechanisms of transgene integration.

Muravyova A., Smirnov A., Battulin N.

Y-box-binding protein 1 as regulator of poly(ADP-ribose) polymerase 1 activity. Naumenko K.N., Sukhanova M.V., Alemasova E.E., Kurgina T.A., Kutuzov M.M., Lavrik O.I.

Application of single-cell Hi-C method for analysis of lampbrush chromosome conformation.

Nurislamov A., Gridina M., Taskina A., Fishman V.

Are short sequence repeats (SSRs) pinpoint evolution hotspots? Cyprinidae fish case study.

Orlov M.A., Tykhonov A.Yu.

Polymorphisms in FAD3A and FAD3B genes that determine the fatty acid composition of flax oil.

Povkhova L.V., Kezimana P., Krasnov G.S., Novakovskiy R.O., Pushkova E.N., Rozhmina T.A.,

Dmitriev A.A., Melnikova N.V.

Using fast homology search tools for protein sequence functional annotation: a comparison.

Pronozin A., Genaev M., Afonnikov D.

High-quality genome assemblies of male and female Populus x sibirica plants. Pushkova E.N.,

Krasnov G.S., Dvorianinova E.M., Novakovskiy R.O., Povkhova L.V., Melnikova N.V., Dmitriev A.A.

Development of DNA markers to create resistant barley varieties based on assisted genomic

loci identification. Rozanova I., Lashina N., Afanasenko O., Khlestkina E.

Photosynthesis of the isogenic lines Triticum aestivum L. Semilet T.V., Silantyeva M.M.,

Khlestkina E.K.

Genes determining dwarfism in Cucurbitaceae. Strygina K., Tekhanovich G., Elatskova A.,

Elatskov Yu., Khlestkina E.

Erythrocytes 3D genome organization in vertebrates. Taskina A., Ryzhkova A., Khabarova A.,

Fishman V., Battulin N.

Development of a test system for evaluating the antiglycative effect of bioactive substances

of medicinal plants. Vashurina N.V., Dubrovskii Y.A., Soboleva A.V., Frolov A.A. 
Development of regulatory loop for the quantitative control of gene expression.

Vasilev R.A., Polushkina I.D.

Molecular dynamic and kinetic characterization of Cas9 mutants for improving specificity

of genome editing tools. Vokhtantsev I., Kadtsyn E.

Search for a new type of spatial organization of nucleic acids in human genome.

Zamoskovtseva A.A., Lomzov A.A., Kabilov M.R., Pyshnyi D.V.

In vitro evaluation of new nuclease class II type V system. Zheltova A., Medvedev D.,

Polushkina I., Vasiliev R.

К вопросу о полногеномном секвенировании иммунного к грибным заболеваниям вида

Vitis Rotundifolia Michaux. Агаханов М.М., Ульянич П.С., Носульчак В.А., Ухатова Ю.В.

Кластеризация возрастных трендов экспрессии генов РВМС. Алексеев А.A.

Междисциплинарное исследование растительных остатков в древнерусском кладе.

Бабиченко Н.П., Пожидаев В.М., Яизииина Е.Б.

Филогенетическое разнообразие культур аноксигенных фототрофных бактерий

из водоемов России. Бахмутова Е., Намсараев З., Комова А.

Скорость и качество решений лингвистических заданий с эмоциональными предложениями как возможный поведенческий маркер, отражающий адаптацию человека к приполярному климату. Белоногов А., Выскребияов А., Таможников С., Борисова Н., Афанасьева Е., Никонов Н., Чикачева С., Савостьянов А.

Молекулярный скрининг образцов кабачка и патиссона (Cucurbita pepo L.) из коллекции ВИР и оригинального селекционного материала Крымской ОСС ВИР на наличие маркеров устойчивости к мучнистой росе. Беренсен Ф.А., Москалу А.Ф., Антонова О.Ю., Кузьмин С.В., Пискунова Т.М.

Изучение распространения и генетического разнообразия Phaeomoniella chlamydospora и Phaeoacremonium aleophilum на территории виноградных насаждений Краснодарского края и Крыма. Блинова С.А., Швариев А.А., Странишевская Е.П., Володин В.А.,

Ильницкая Е.Т., Макаркина М.В., Алексеев Я.И.

Эффект использования полных митохондриальных геномов и их отдельных фрагментов для делимитации видов. Болбат А.В., Болбат Н.Б., Васильев Г.В.' Богданова В.С., Матвеенко Е.Ю., Кайгородова И.А.

Исследование коэволюционных процессов в системе паразит-хозяин на примере видов рода Mycobacterium sp. Бондаренко Т.А., Бородулин А.В., Борунова В.В., Луданный Р.И.

Исследование повторяющихся последовательностей генома образцов конопли посевной (Cannabis sativa L.). Бочаркина Ю.В., Разумова О.В., Карлов Г.И.

Особенности выделения нуклеиновых кислот из эфиромасличных растений. Браилко В.А., Булавин И.В., Гребенникова О.А., Митрофанова И.В.

Изучение генетической регуляции накопления кутикулярного воска ячменя при помощи анализа данных RNA-seq. Вихорев А., Шмаков Н., Колосовская Е., Короткова А., Герасимова С., Хлесткина Е.

Вызванные потенциалы головного мозга (ERPs) в условиях решения лингвистических задач как нейрофизиологический маркер адаптации к приполярному климату. Выскребияов А., Белоногов $A$., Таможников С., Сапрыгин А., Борисова Н., Карпова А., Афанасьева Е., Савостьянов А. 
Сравнение методов выделения высокомолекулярной ДНК из плодов растений для нанопорового секвенирования. Гладышева-Азгари М.В., Петрова К.О.

Хромосома линии половых клеток зебровой амадины: анализ повторяющихся последовательностей. Давидьян А., Володькина В., Комиссаров А., Галкина С.

Разработка биосенсоров для количественной оценки уровня аминокислот in vivo.

Евтеева М.А., Васильев Р.А.

Направленный нокаут гена вакуолярной инвертазы Pain-1 в Solanum tuberosum L. Егорова А.А., Герасимова С.В., Коэппель И., Хамаз С., Хикель Ш., Хертиг К., Ибрагимова С.М., Сабоиев И.А., Нестеров М.А., Кумлен Й., Салина Е.А., Кочетов А.В.

Определение последовательности кластера рДНК у японского перепела. Жукова А.А., Галкина С.А., Комиссаров А.С., Сайфитдинова А.Ф.

Взаимосвязь активности сетей покоя мозга с динамикой риска депрессии и уровня тревожности у трудовых мигрантов в приполярных районах Якутии. Заварзин $E$., Таможников С., Милахина Н., Борисова Н., Афанасьева Е., Никонов Н., Чикачева С., Савостьянов А.

Сегментация и детекция структурных элементов колоса пшеницы. Заварзин $E$.,

Приходько А., Прохошин Н., Комышев Е., Генаев М.

MGSGenerator 1.5: инструментарий для реконструкции математических моделей метаболических сетей. Казанцев Ф.В., Лашин С.А.

Роль ключевого белка мисматч репарации млекопитающих MSH2 в эпигенетических изменениях при онкогенезе. Каххарова З.И., Грин И.Р.

Влияние ферментов эксцизионной репарации оснований ДНК на активность АР-эндонуклеазы человека. Кладова О.А., Федорова О.С., Кузнеиов Н.А.

Особенности редиса европейского при получении DH-растений в культуре микроспор in vitro. Козарь Е.В., Домблидес Е.А., Солдатенко А.В.

Нейротрофическое обеспечение коры головного мозга при болезни Альцгеймера: транскриптомный анализ. Козлова Т.А., Рудницкая Е.А., Стефанова Н.А., Колосова Н.Г.

Идентификация регуляторного гена, контролирующего синтез кутикулярного воска ячменя. Колосовская Е.В., Герасимова С.В., Короткова А.М., Хертиг К., Морозов С.В., Черняк Е.И., Домрачев Д.В., Кочетов А.В., Кумлен Й., Хлесткина Е.К.

Получение линий растений мутантов и анализ полученных популяций после геномного редактирования по гену Nud у ячменя. Короткова A.M., Колосовская E.В., Герасимова С.В., Кукоева Т.В., Хлесткина Е.К.

Геномное редактирование цианобактерий с целью получения промышленно значимых продуктов. Кувырченкова А.П.

Влияние экзогенных конечных продуктов глубокого гликирования на первичный метаболом культуры Rhizobium leguminosarum. Кузнецова А., Шумилина Ю., Династия Е., Илинг К., Попова В., Гришина Т., Васко Видал А., Зини А., Вестерманн Б., Фролов А.

Разработка алгоритмов для нахождения факторов транскрипции и их сайтов связывания в аннотированных бактериальных геномах. Лахова Т.Н., Ощеепков Д.Ю., Мухин А.М., Лашин С.А.

Новый вид байкальской эндемичной губки: морфологический и молекулярно-генетический анализ (на основе полного митохондриального генома). Майкова О.O. 
Применение генетических и биоинформационных подходов к познанию биоразнообразия на примере эндемичных рыбьих пиявок Baicalobdella (Hirudinea, Piscicolidae) из озера Байкал. Матвеенко Е.Ю., Кайгородова И.А.

Поиск и оценка белков нуклеаз II класса в геномных и метагеномных данных.

Медведев Д.О., Желтова А.В.

Использование фототрофных микроорганизмов для очистки сточных вод и получения биоудобрений. Мельникова А., Kuchendorf C., Комова А., Руденко А., Намсараев 3.

Сравнительный анализ ансамбля транспозонов некоторых геномов. Мутовина O.A.

Биоразнообразие эндофитов винограда Vitis amurensis Rupr. Нитяговский Н.H.,

Киселев К.В., Алейнова О.А.

Распознавание генотипа колоса пшеницы методами Computer Vision. Паулиш A.,

Пронозин А., Комышев Е., Генаев М.

Генетическое сходство Gyrodactylus sphinx (Platyhelminthes: Monogenea) из Черного моря с новым подродом морских видов, обитающих в юго-восточной части Тихого океана, а также в Средиземном и Северном морях. Прохорова Д.А., Дмитриева Е.В., Водясова Е.А.

Разработка и апробация хлоропластных праймеров для анализа гаплотипов хурмы коллекции ФИЦ СНЦ РАН. Рахмангулов Р.С., Симонян Т.А., Маџькив А.О., Цатурян Г.А., Шуркина Е.С., Омаров М.Д., Кулян Р.В., Омарова 3.М.

Сравнительный транскриптомный анализ в динамике развития протеинопатии на мышиной модели бокового амиотрофического склероза FUS(1-359). Pезвых A., Устюгов А.А.,

Морозов А.В., Евгеньев М.Б., Фуников С.Ю.

Количественная оценка концентрации хлорофилла $a$ фототрофных микроорганизмов в воде с помощью методов машинного обучения и камеры мобильного телефона.

Руденко А.П., Теслюк А.Б., Мельникова А.А., Намсараев З.Б.

Идентификация аллелей $\mathrm{S}$ гена самонесовместимости у сортов черешни. Смирнов P.B.

Особенности применения регуляторов роста в технологии производства саженцев яблони в условиях предгорной зоны садоводства. Смирнов P.B.

Иммуногенетические предикторы раннего прерывания беременности. Татаркова E.,

Тугуз А., Шумилов Д.

Проект создания геномно-географического атласа автохтонных сортов винограда России.

Распределение генов митохондрий грибов в пространстве частот триплетов.

Федотовская В.Д., Шиагина Т.О., Колесникова А.И., Садовский М.Г.

Видовая идентификация энтомопатогенного гриба с помощью молекулярно-генетического анализа. Чемезова А.А., Майкова О.О.

Ассоциация G1181C полиморфизма гена TNFRS11B с риском развития ишемической болезни сердца у жителей Республики Адыгея. Шумилов Д., Тугуз А., Татаркова Е. 
Научное издание

\section{SYSTEMS BIOLOGY AND BIOINFORMATICS (SBB-2020)}

The Twelfth International Young Scientists School Abstracts

Printed without editing

\section{СИСТЕМНАЯ БИОЛОГИЯ И БИОИНФОРМАТИКА (SBВ-2020)}

Двенадцатая школа молодых ученых

Тезисы докладов

Публикуется в авторской редакциии

Выпуск подготовлен информационно-издательским отделом ИЦиГ СО РАН

Подписано к печати 01.09.2020. Выход в свет 10.10.2020

Федеральный исследовательский центр «Институт цитологии и генетики

Сибирского отделения Российской академии наук» (ИЦиГ СО РАН)

630090, Новосибирск, проспект Академика Лаврентьева, 10 
(

(0) 